10 19
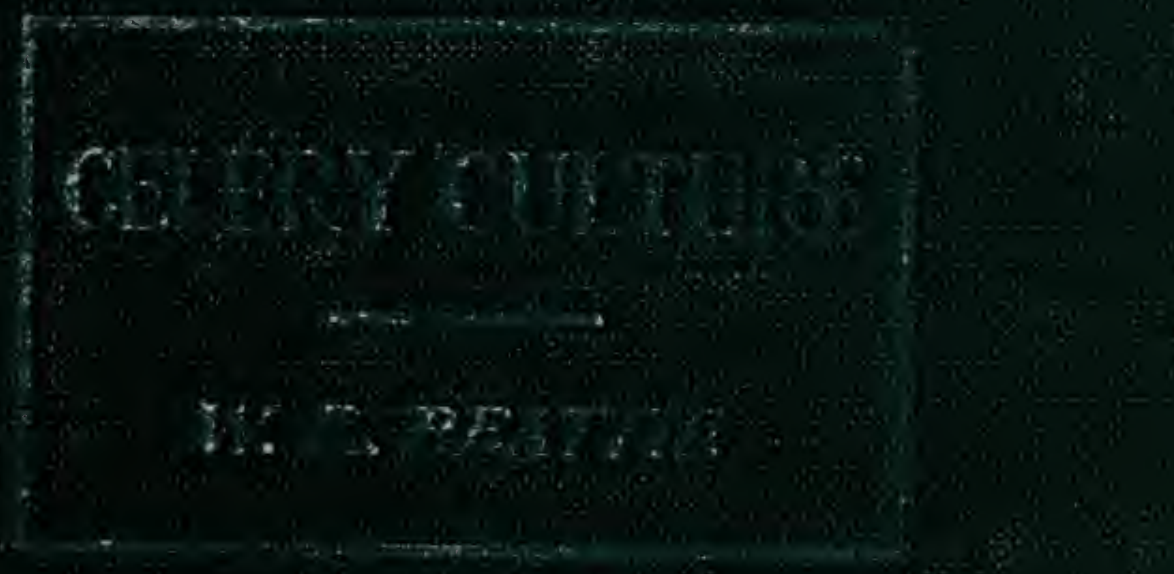

$* \frac{2}{4}$

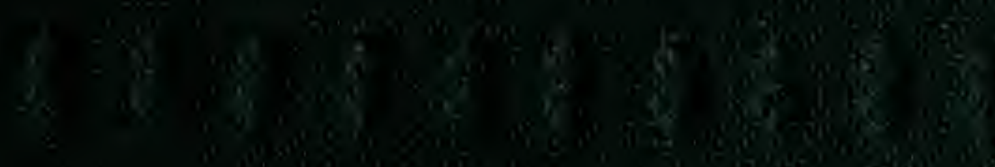




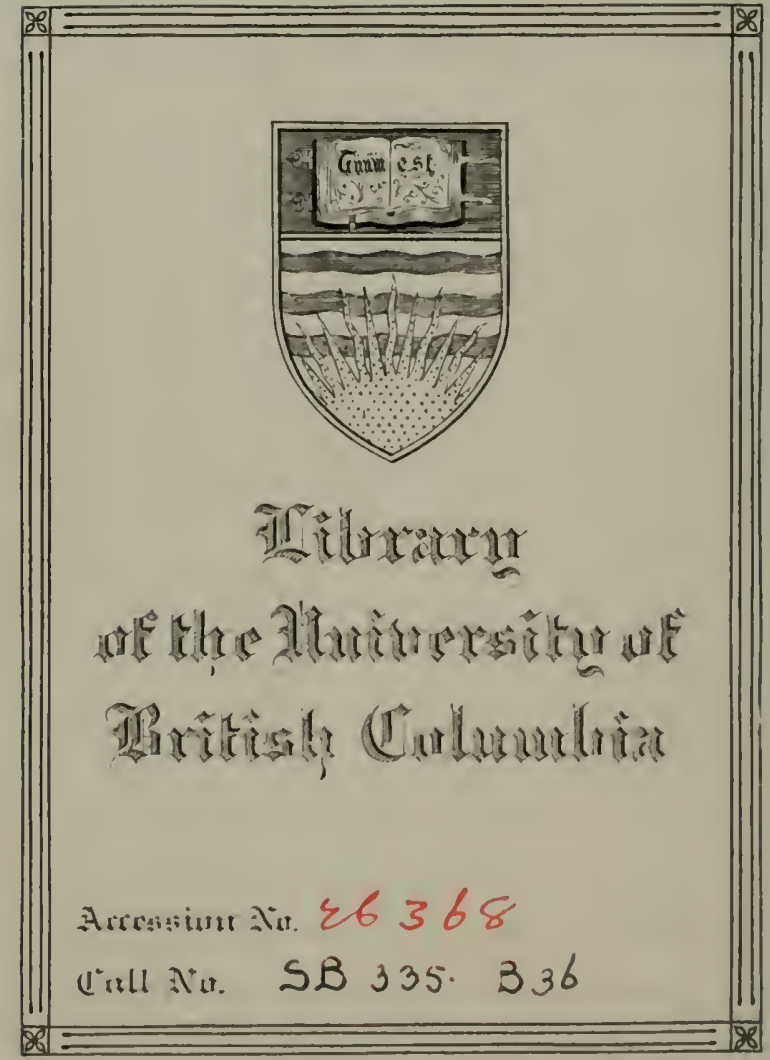







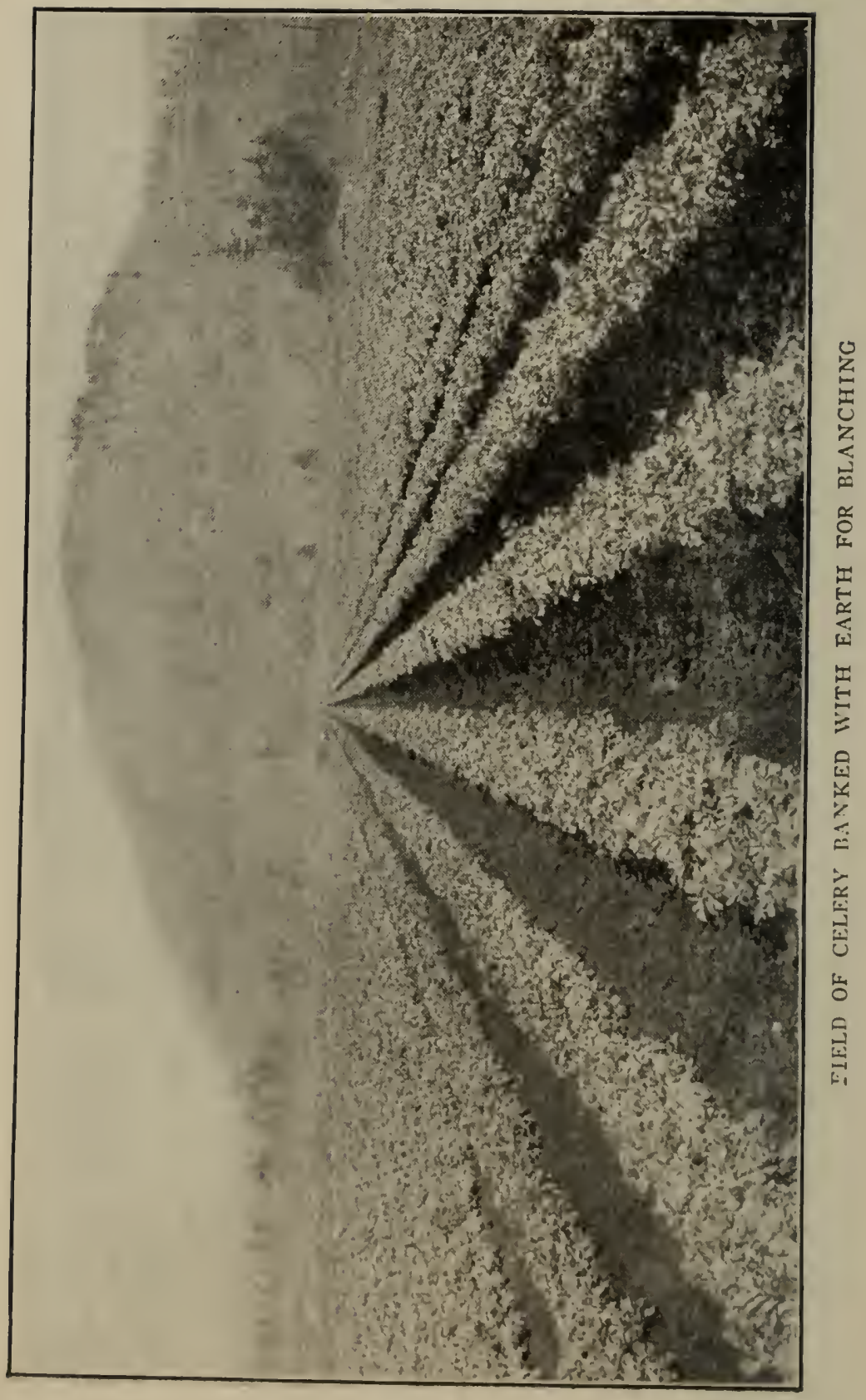




\section{CELERY CULTURE}

A PRACTICAL TREATISE OF THE PRINCIPLES INVOLVED IN THE PRODUCTION OF CELERY FOR HOME USE AND FOR MARKET, INCLUDING THE SELECTION OF SOIL PRODUCTION OF PLANTS, CULTIVATION, CONTROL OF INSECIS AND DIS-

EASES, MARKETING AND USES

By

W. R. BEATTIE

Assistant Horticulturist, Büreàu of Plant Industry

United States Departmenit of 'Ägriculture

ILLUSTRATED

NEW YORK

ORANGE JUDD COMPANY 


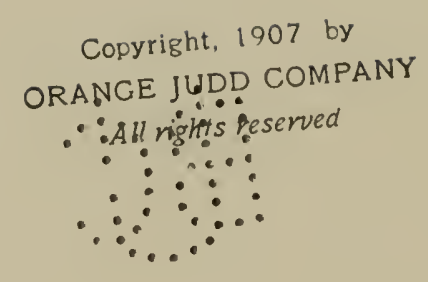

Printed in U. S. A. 


\section{PREFACE}

CELERY growing on a commercial basis in America practically began with the introduction in $1884-5$ of early varieties having decided self-blanching qualities. P'revious to this time, most of the celery was stored for winter use, but with the introduction by Peter Henderson in I884 of the variety known as White Plume the crop began to be produced on a large scale for early marketing. During the following year the Paris Golden or Golden Self-blanching was introduced from France and soon became a favorite variety among growers. Since the introduction of the self-blanching varieties, the celery industry has grown by leaps and bounds until the crop is now planted in almost every part of the North American Continent.

During recent years the agricultural and horticultural journals of this country have published numerous articles upon celery culture, and two or three small books have been written upon the subject. The available literature upon the subject of celery culture is limited, but as a rule is based upon actual, commercial experience. Our first recollection of celery is of a few half-starved plants set cleep down in a trench where their source of nourishment was the heavy subsoil that surrounded their roots. Contrast with this the broad, fertile, level-cultivated celery field of to-day, with its vigorous growth and luxuriant foliage.

In most respects the transportation and marketing 
of the celery crop have kept pace with the improvement in production. Formerly the entire crop was washed and bunched before shipment, but it has been learned that celery will bear transportation much better if a part of the roots and outer stems are allowed to remain upon it until after shipment. There are yet a number of vexing problems connected with the commercial production of celery, prominent among which are the control of diseases and the securing of competent labor.

In this book an endeavor has been made to give plain directions both for the production of a home supply of celery and its culture on an extensive commercial basis. The information has been obtained from practical experience and from observation of the methods employed by the most successful growers. Many of the illustrations are from photographs taken upon a number of the most extensive celery plantations in the comtry. The author is indebted to the United States Department of Agriculture for the loan of several illustrations; to Prof. W. G. Johnson for several photographs; to B. F. Williamson for many of the excellent drawings; and, finally, to a number of seedsmen and tool manufacturers for courtesies extended.

With the exception of those for which credit is given, all the illustrations are original.

W. R. Benttie.

Washington, D. C., April, 1907. 


\section{CONTENTS}

INTRODUCTION

History and botany of the celery plant, 1; importance of celery as a food plant, 2.

\section{Areas Adapted to Celery Cuiture}

Climatic requirements of the celery plant, 3 ; soils adapted to celery culture, + ; marketing considerations, 5; labor requirements, 6 .

\section{Preparation of Land}

Drainage, 7 ; treatment of new land, 8; breaking and pulverizing land, 9; fitting southern land for celery, 11; preparation for planting, 13.

\section{FerTILIZERS}

Natural fertility of soils, 16; chemical elements required in fertilizers, 17; sources of nitrogen, 17; suurces of phosphorus, 18; sources of potassium, 18; sources of calcium, 19; common salt as a fertilizer, 19; barnyard or stable manure, 20; manure from fowls, 22; fish refuse, fisl scrap, fish guano, 22; Peruvian guanos, 23; night soil and sewage as fertilizers, 23 ; the application of fertilizers, 23 ; cost of fertilizers for an acre, 25; time for applying fertilizers, 26; home mixing of fertilizers, 28; suggestive mixtures for use on peat or muck soils, 29; mixtures for use on clay and sandy soils, 29.31; tablc of fertilizer values, 32 .

\section{The Production of Plants}

Necessity of having good seed, 35 ; methods of sowing seed for early plants, 36 ; starting plants in a window box, 36 ; starting plants in a grcenhouse or hotbed, 37 ; construction and care of hotbeds, 38; temporary hotbeds, 38; permanent liotbeds, 39; coverings for hotbeds, 40 ; ventilating and wa. tering the liotbed, 41 ; construction, care, and uses of coldframes, 41 ; sterilization of soil for seed-bed, 42; starting plants in the open ground, 43 ; care of the outdoor seedbed, 45; protection of plant beds, 45; transplanting, 47; substitutes for transplanting, 49; proper time to plant seed, 50.

\section{Planting in Field and Garden}

Lifting the plants, 52; packing celery plants for shipment, 53 ; setting in the open ground, 54 ; distances to plant, 56; table of planting distances, 58 ; overconining unfavorable conditions at planting time, 59; mulching, 59 .

\section{Cultivation}

Frequency of cultivation, 61; tools adapted to celery cultivation, 61. 
IRRIGATION • • • . •

Sources of water for irrigation, 65; quantity of water re. ting, 67; woudcu flumes and open ditches, 68; overheacl sprinkler systems, 69; subirrigation as applied to celery growing, 72 ; temperature of water for celery irrigation, 76.

Diseases of Celery . . . . . . . .

Damping, 77; blight. 78 ; leaf spot, 80 ; celery rust, 81 ; blanch-rot or heart-rot, 81 ; root-knot, 82 ; prevention and control of celery diseases, 83 ; preparation of spray mixtures, $83-85$; pithiness of celery, 87 ; general suggestions, 89 .

\section{Insects and Animals Injurious to Celery}

Grasshoppers, 91 ; the celery leaf-tyer, 91 ; the celery cater. pillar, 92; the zebra caterpillai, 92; the tarnished plant bug, 92 ; the carrot rust fly, 93 ; the celery looper, 93 ; mice and rats, 93 ; poultry, 94.

\section{BLANCHING}

Blanching by means of boards, 96; time required for blanch. ing process, 98 ; banking with earth, 99 ; blanching with tile, 102 ; various methods of blanching celery, 103; blanching for winter use, 103.

\section{Storing Celery}

Storing where grown, 104; storing in temporary pit or vacant hotbed, 105; storage in cellars, 107; trencling for late autumn marketing, 107; storing for late marketing, 108; methods of handling celery for storing, 109; cold-storage, 111.

\section{Marketing}

Methods of preparing celery for market, 112; sizes and styles for shipping crates, 114; washing and bunching be. fore shipment, 116; the celery packing hotse, 117; construction of washing machines, 119 ; buncling and packing. 120; sanitary considerations in marketing celery, 122; keep. ing celery fresh while exposed for sale, 124.

\section{VARIETIES OF CELERY}

Self-blanching varieties, 125 ; late keeping varieties, 126; varieties for home use, 128; celeriac or turuip-rooted celery, 129; varieties for marketing, 129.

\section{Profits Derived from Celery Culture}

Cost of growing, 130; procecds from one acre, 131.

The Production of Celery Sied

Localities where grown, 132; method of growing, 132; local production of seed, 132-133. 


\section{L LUSTRATIONS}

FIGURE

PAGE

Field of celery banked with earth for blanching

Frontispiece

1. Heavy plow for breaking bog or marsh land . 8

2. Heavy subsoil.plow for loosening clay subsoils . 9

3. Improved sectional clod crusher and leveler . 10

4. Acme harrow for fitting land after plowing . 10

5. Breaking Florida hammock for celery . . 11

6. Home-made float or drag for leveling soil a 12

7. Meeker harrow for smoothing surface for planting 13

8. Horse-boots for soft or boggy land . . . 14

9. Machine for marking distances to plant . . 14

10 Tray for seed sowing or transplanting . . 36

11. Cross-section of temporary hotbed . . . 39

12. Cross-section of permanent hotbed . . . 40

13. Cross-section of cold-frame with muslin shade . 42

14. Cloth-protected celery plant bed for home garden 46

15. Celery plant bed under slat shade . . . 46

16. Effect of transplanting upon the roots . . 47

17. Device for cutting roots in seed-bed . . . 48

18. Transplanting celery plants in Florida . . 49

19. Crate of celery plants packed for shipment . 54

20. Setting celery plants in field . . . 55

21. Dibbles for use in setting celery plants . . 55

22. Setting celery plants in the home garden. 57

23. One-horse cultivator . . . . . 62

24. The wheel hoe . . . . . 62

25. Hand-weeding tools for working around celery plants . . . . . 63

26. Deluge sprinkler system of irrigating . . 70

27. Skinner system of overhead watering . . 71

28. Arrangement of tiles for subirrigation . . 73 
29. Subirrigation adapted to back-yard garden . 74

30. Subirrigation system as employed in Florida . 75

31. Leaf affected with celery blight . . . 79

32. Celery leaf affected with a blight . . . 80

33. Celery leaf affected with leaf-spot . . . 81

34. Celery leaf affected with rust . . . . 82

35. The proper way to make Bordeaux . . $\quad 85$

36. Home-made spraying machine . . . . 86

37. Celery leaf-tyer . . . . . . 91

38. Blanching celery by means of boards . . 97

39. Planet Jr. Double celery hiller . . . . 98

40. Blanching celery with earth . . . . 100

41. Blanching celery by means of drain tiles . . 102

42. Temporary storage-pit for celery . . . 106

43. Celery storage house. . . . . 108

44. Machine for loosening celery from the soil .110

45. Washing and bunching celery in commission merchant's room . . . . . 113

46. Row of blanched celery ready for cutting : . 114

47. Packing celery in crates in California field . 115

48. Crates of celery shipped in the rough . . 116

49. Crate of Florida celery shipped in the rough . 117

50. Celery trimmed for market . . . . . 118

51. Floor plan of celery packing-house . . . 119

52. Bunch of celery containing one dozen plants . 121

53. Device for bunching celery . . . . 122

54. Michigan crate . . . . . . . 123

55. Device for displaying celery on retail market . 124

56. Typical plant of Golden Self-blanching . . 126

57. Florida celery land . . . . . . 135

58. Celery prepared for table use . . . . 136

59. Packing celery in Florida . . . . . 138 


\section{CELERY CULTURE}

\section{CHAPTER I}

\section{Introduction}

VERY little is known regarding the early history of celery, and its use as food is confined to comparatively recent years. The present product, so highly esteemed as a table delicacy, is the result of selection and cultivation of the wild celery which is a native of the marshes of southern England and many places in Continental Europe. The Latin or scientific name of celery is Apium graveolens, and it belongs to the Apiaceae, a family of plants formerly classed under Umbelliferae. In its natural state celery is a biennial, producing its seed the second season, but as commonly grown for food it is an annual. If started too early, or allowed to remain in the ground too long after it reaches a marketable stage, it will produce seed the first season. The parts of the celery plant used for food are the thickened leaf-stems and the fleshy root, the true stem being that upon which the flowers and seed are borne. The seeds of the celery are very small, an ounce containing from 60,000 to 70,000 , and are borne in great numbers in umbels or clusters. In the wild state celery has an acrid, pungent flavor, 
and was used only for seasoning, while the improved form is more fleshy and has a pleasant odor and flavor. Celery growing on a commercial scalc in America made its greatest progress after the opening and draining of the peat marshes in the region of the Great Lakes. During recent years celery growing has been introduced in Florida and California, and its season of production thereby greatly extended.

While celery may not possess much actual food value, it is both attractive and wholesome; coming as it does at the time of year when large quantities of meats and game are consumed, and green foods are not plentiful, the use of celery makes other foods more palatable and greatly aids digestion. While cranberry sauce may seem essential to the serving of the Christmas turkey, it is now decmed just as important to have a generous supply of fresh, crisp celcry on the table. Several thousand car-loads of celery are now consumed each year by the people of our larger cities, besides the many smaller lots niarketed locally by the growers. In many home garlens there is now planted a small area to celery and we have no record of the vast amount of this delicious salad vegetable thus produced. It should be borne in mind that the taste of celery is at first unpleasant to some persons, but they usually acquire a liking for it after eating it a few times. 


\section{CHAPTER II}

\section{Areas Adapted to Celery Culture}

While a sufficient supply of celery for family use may be grown in almost any locality in America, there are only certain regions particularly adapted to its commercial culture. Where roo to 500 plants are grown for home use, such agencies as sheltering, shading, special preparation of soil, and frequent watering may be permissible, although such methods would prove impracticable for commercial celery growing.

Climatic Requirements of the Celery Plant.The production of celery on a large scale for shipping is only practical where the climatic conditions are reasonably favorable. For its best development the celery plant requires a comparatively dry atmosphere and cool nights. Warm, sultry weather is conducive to a soft growth, and conditions favorable to the attack of discases. Bright sunshine and warmtl during the day are essential, but the cooling during the night makes the stems crisp and firm.

In America there are two zones or belts within which celery can be grown with profit commercially: (I) the northern belt throughout which the crop may be grown during the summer months, and (2) the southern belt within which it may be grown during the late autumn and early winter. In the northern belt the area is limited by the short- 
ness of the season on the north and the high temperature and humidity on the south. In the southern belt the area is limited by that wherein severe frosts do not occur during the winter months. This leaves a zone through the Central Southern states wherein the winters are too severe and the summers too warm and humid for the commercial production of celery. There are no doubt a number of areas within these boundaries, which, owing to altitude or some other influence, may prove exceptional.

Soils Adapted to Celery Culture.-For domestic use, a deep, rich, sandy loam will produce the best celery, but a small supply may be grown on almost any good soil. In the regions where peat bogs or muck soils abound the crop can be very easily grown upon these, and the greater portion of the commercial crop is produced upon this type of soil. The first crops of celery of commercial importance in this country were grown on the muck beds adjacent to Kalamazoo, Michigan. There are now many thousands of acres of muck soil situated in the states bordering on the Great Lakes that are devoted almost entirely to celery production. In Floricla the similar soils, often spoken of as "Hammock soils" and "Sawgrass marshes," are used for celery production, and the soils of the great celery fields of southern California are similar in character. For the production of celery on a small scale it is practical to render any good garden soil suitable by manuring heavily and providing proper drainage. 
Marketing Considerations.-Marketing facilities should be carefully considered when contemplating the culture of celery on a large scale. Markets are of two classes-namely, home markets where the entire product may be hauled by wagon and disposed of direct to the retail dealers or the consumers, and distant or shipping markets. Some localities offer the opportunity of disposing of a part of the product on the home market and the remainder on some distant market. The home market generally reduces the cost of packing and shipping, and as a rule affords a higher price for the product. Owing to the bulk of celery it is desirable that the field where it is produced should not be located at a greater distance than 5 miles from the home market. The shipping market will provide for a larger acreage and permit the crop to be removed more rapidly than if the local market were depended upon. For satisfactory shipping facilities, the railroad sidings should not be more than 2 miles from the more distant parts of the celery fields, and it is preferable to have a loading track running directly through the fields, and the cars distributed as nearly as possible to the points where the celery is being packed. It is often possible to dispose of one grade of celery on the home market and another grade by shipping, but where large quantities are grown the local markets cannot be relied upon. The possibility of securing cars, direct rail connections to the larger cities, and satisfactory freight rates, are matters that should receive careful attention before undertaking a large celery growing enterprise. 
Labor Requirements.-The production of celery on a commercial scale requires a large amount of labor at certain times of the year, and it is necessary to determine where this labor is to be secured at the times when needed. In parts of the country where lumber is scarce, the cost of the boards for blanching may be prohibitive, in which case it will be necessary to blanch with earth, greatly increasing the amount of labor required. In spite of the fact that there have been a large number of very satisfactory tools devised for handling the celery crop, there remains considerable labor that must be performed by hand. No satisfactory machinery has been devised for setting the plants, hoeing between the plants, putting on the finishing touches in banking, cutting and trimming, or bunching and packing in crates. It is true that there are a number of devices intended to assist in the different operations, but they cannot do the work themselves. The character of the available labor must also be taken into consideration, as many of the operations connected with the handling of a celery crop require care and skill. For the general operations, such as hoeing, banking, boarding up, and lifting, almost any class of labor may be employed, provided the helpers are arranged in gangs under the direction of competent foremen. A number of the large growers provide that the foremen shall share in the profits clerived from their portion of the crop, and are thus enabled to secure more careful supervision. 


\section{CHAPTER III}

\section{Preparation of Land}

As a rule, comparatively new land is selected for celery growing, and it is necessary to first remove all trees, stumps, and other obstructions to plowing and cultivation.

Drainage.-While celery requires a large amount of moisture for its growth, there is no crop that will be injured more quickly by excessive water and sour soil; for this reason it is necessary to secure good drainage. The drainage may be accomplished by means of open ditches or by tile drains, provided the character of the soil is such that the tiles will not become filled with silt within a short time.

In some cases the drainage and irrigation systems may be combined in one. Where the open ditch system of drainage is employed, the laterals should not be at greater intervals than 300 feet, and much closer in most soils. The lateral ditches should drain into a main ditch having a greater depth and capacity in order to carry off the surplus water during heavy rains. Tile drains should be placed at a distance not greater than 6 rods apart; 3 rods will give the better results. All open ditches should be constructed with gently sloping sides, and the earth worked well back from the sides of the ditch, in order that the surface water 
may drain off easily. 'The soil may be worked back from the sides of the ditches by plowing toward the center of the beds.

Treatment of New Land.-Newly cleared land that is broken up in the spring. should not be planted to celery; but should be devoted to some such crop as corn or cowpeas for one season to reduce the soil to a proper condition for intensive cultivation. If the land is first broken during the later part of the summer it should be allowed to lie fallow until autumn and then plowed a second

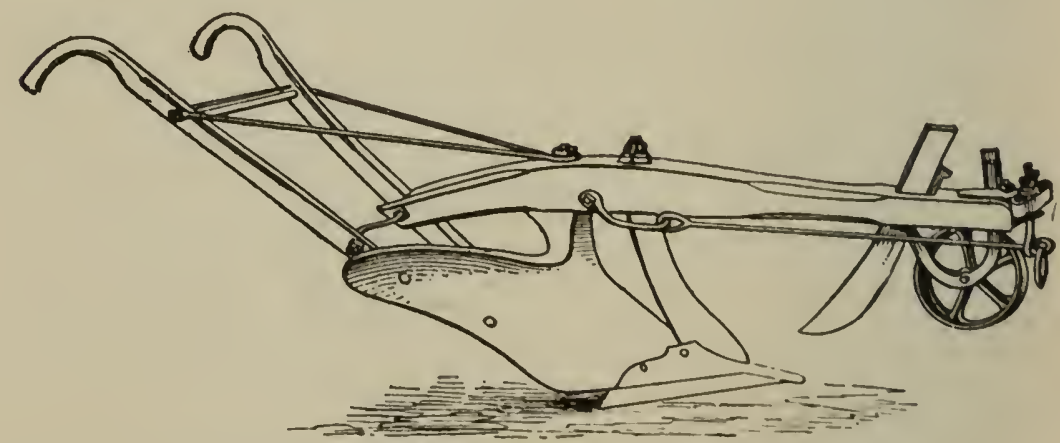

FIG. I-HEAVY THREE-HORSE BREAKING PLOW

time. The first plowing should be performed with a heavy three-horse breaking plow, such as is illustrated in Fig. I, in order that the soil may be turned deeply and well broken up. This is especially inportant when handling muck, peat, or marsh lands that are being broken for the first time. In preparing a sandy loam for celery growing, the breaking should be done with an ordinary two-horse turning plow. As a rule the sandy soils have a clay subsoil, and the action of soil moisture is in- 
proved by loosening the subsoil, none of which, however, should be brought to the surface. As a rule, subsoiling should be done during the autumn, and it is accomplished by following in the furrow

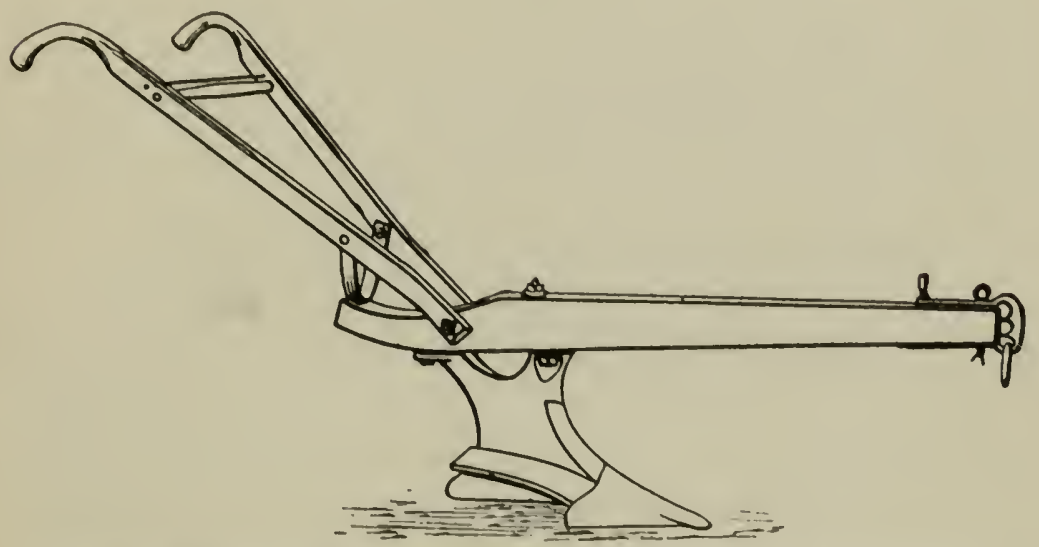

FIG. 2-HEAVY SUBSOIL PLOW FOR LOOSENING CLAY SUBSOILS

behind the turning plow with a regular subsoiler of the type shown in Fig. 2. Subsoiling should be repeated every three or four years but each time in a different direction.

Breaking and Pulverizing Land.-If marsh land breaks up lumpy or in turf, it will be necessary to cut it thoroughly, in at least two directions, by means of a disk or cutting harrow. After cutting the land a spring tooth harrow will be found serviceable for working over the soil and collecting any roots or other trash that may have been loosened by the disk. Where the land remains lumpy after cutting with the disk harrow a sectional roller of the type shown in Fig. 3 will prove efficient. This tool has the advantage over the old 
type of land roller in that it breaks the clods by a grinding process, and when used alternately with the disk harrow it is much more effective. The

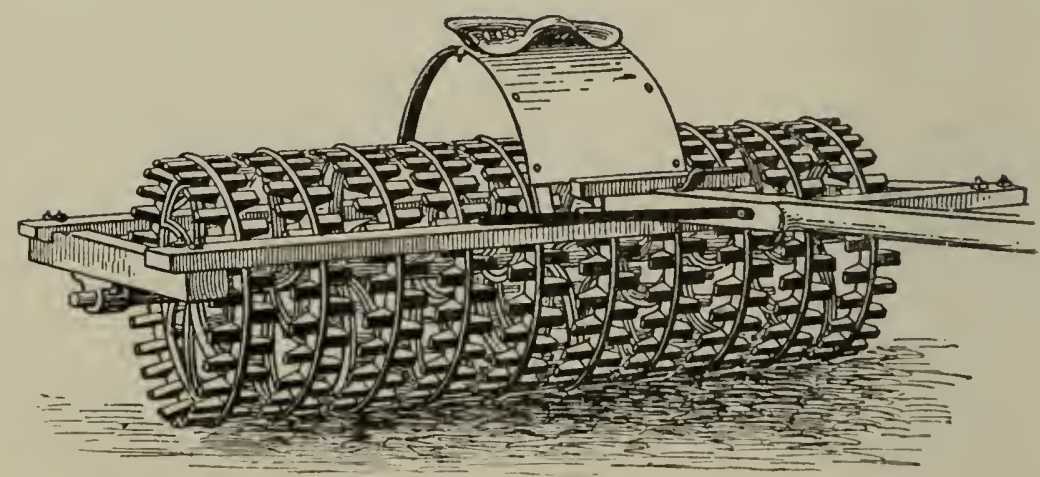

FIG. 3-IMPROVED SECTIONAL CLOD CRUSHER AND LEVELER

acme harrow, which is shown in Fig. 4, is a desirable tool for use on muck and sandy soils, as it turns, smooths, and slightly compacts the soil at one operation.

In the North the work of preparing the land should be done during the autumin, in order that the

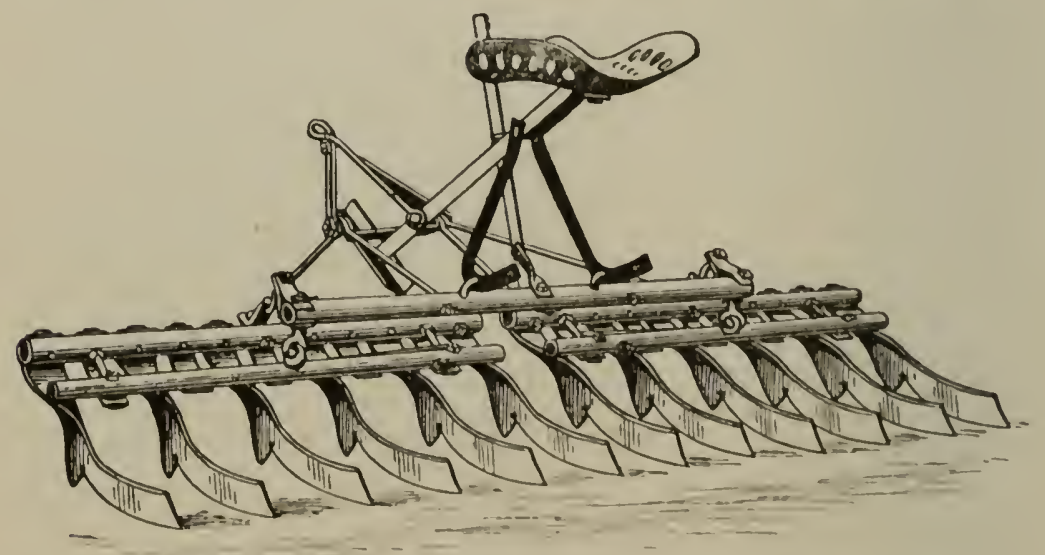

FIG. 4-ACME HARROW FOR FITTING LAND AFTER PLOWING 
surface soil may be exposed to the weather during the winter months. A crop of early peas or snap beans can frequently be grown upon the land intended for planting to celery, and afterward prepared for celery by plowing lightly or by diskingdeeply. It is doubtful if the planting of an early crop upon the celery land will be found profitable

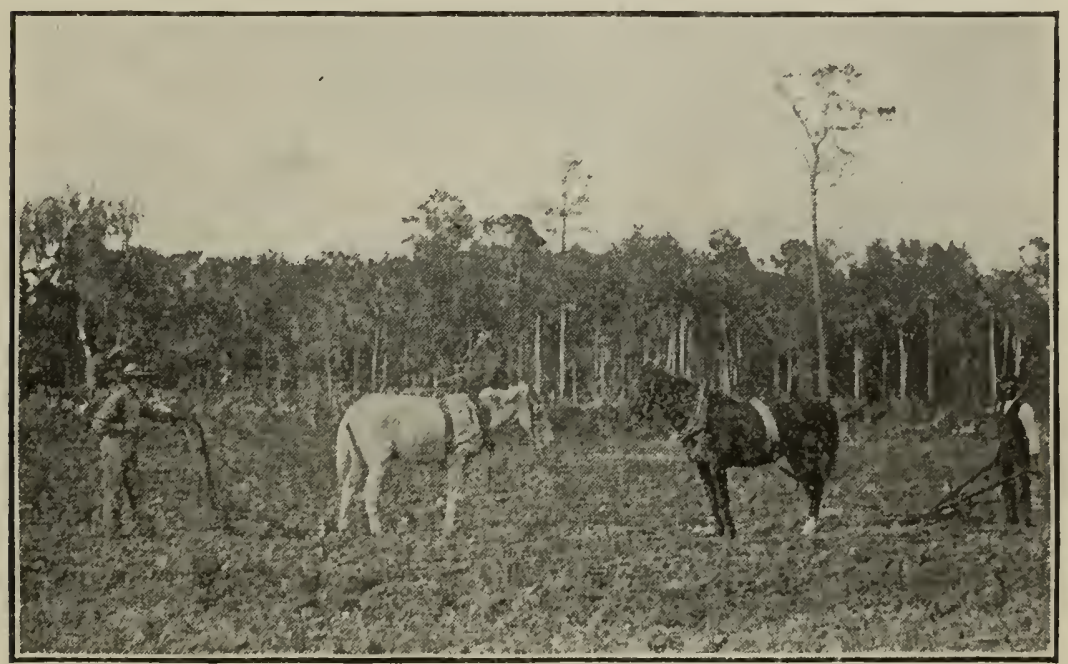

FIG. 5-BREAKING NEW LAND FOR CELERY ON A FLORIDA HAMMOCK-ORIGINALLY COIERED WITH PALMETTOS

(Photo by courtesy American Agriculturist)

in northern localities, as it is desirable to have the land available at any time for applying fertilizers and preparing the soil to receive the celery plants at the proper time for setting them.

Fitting Southern Land for Celery.-In the preparation of Southern lands for celery culture the process is essentially the same, except that the plants are set late in the summer or during the 
autumn, and the land should be prepared during the summer months. Where freezing does not occur, there would be a loss of fertility by allowing the land to lie idle; if the land is cleared some time before wanted for celery it should be planted to some

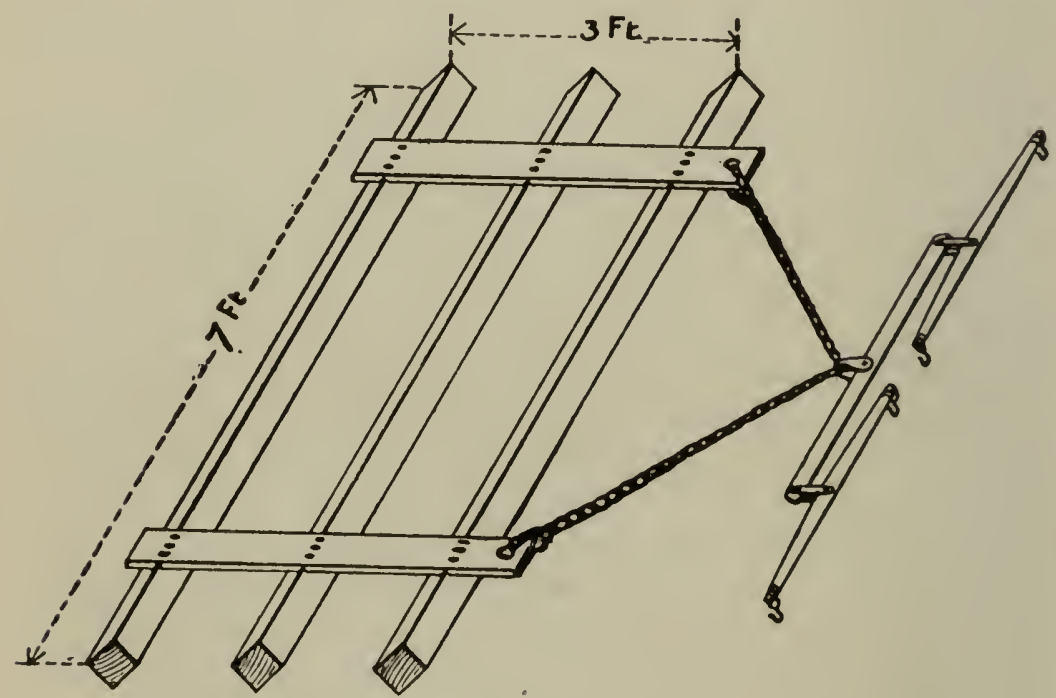

FIG. 6-HOME-MADE FLOAT OR DRAG FOR LEVELING SOIL

cover crop-such as cowpeas or velvet beans-and these removed or turned under before planting to celery. Land that has been in celery during the winter months is generally devoted to tomatoes, cucumbers, or beans during the early spring months, and these may be followed by the cover crop during the summer.

Preparation for Planting.-Several days before setting the plants, the land should receive the final harrowing, and the day before planting the surface should be smoothed by means of a float or 
drag, constructed by nailing together three pieces of square scantling, as shown in Fig. 6 . The Meeker harrow, as illustrated by Fig. 7, is a splendid tool for imparting a smoothness to the surface of the soil, as it performs practically the same work as a steel rake and is rapid in its operation. Just ahead of the transplanters the land is marked off in rows, either with a flat-soled, three-shoe

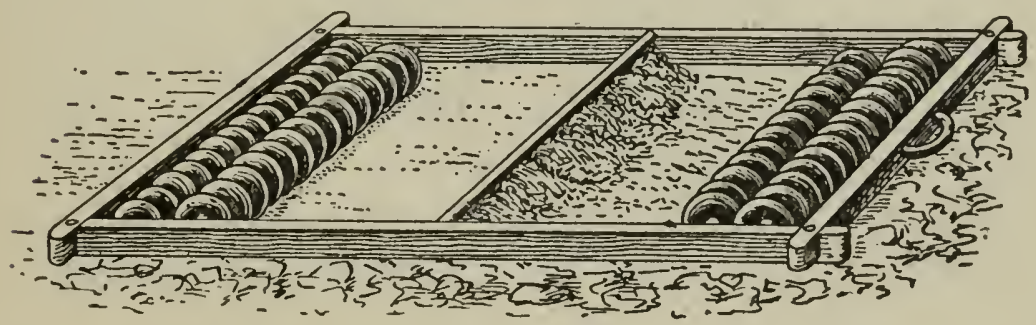

FIG. 7-MEEKER HARROW FOR SMOOTHING SURFACE FOR PLOWING

marker, or by means of one of the various types of special marking machine, which can be home manufactured. Some of these marking devices merely indicate the row and compact the soil slightly, leaving the transplanters to gauge the distance between the plants.

A satisfactory marking device consists of two wheels, or rollers, each having a face 6 to 8 inches wide and equipped at regular intervals with round-pointed pegs which form the holes for setting the plants. This form of machine can be constructed to be drawn by a horse or by hand. If a horse is employed to draw the marker, the horse should be provided with boots as illustrated in Fig. 8, to prevent sinking into the soft soil. 
The construction of the roller marker should be such that the rollers can be set any distance apart

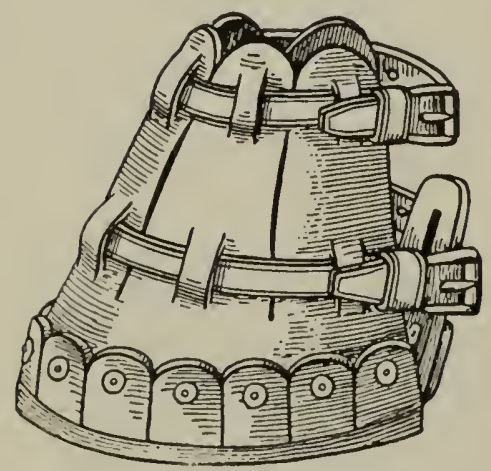

FIG. $8(a)$-LEATHER HORSE-BOOT

to provide for mark

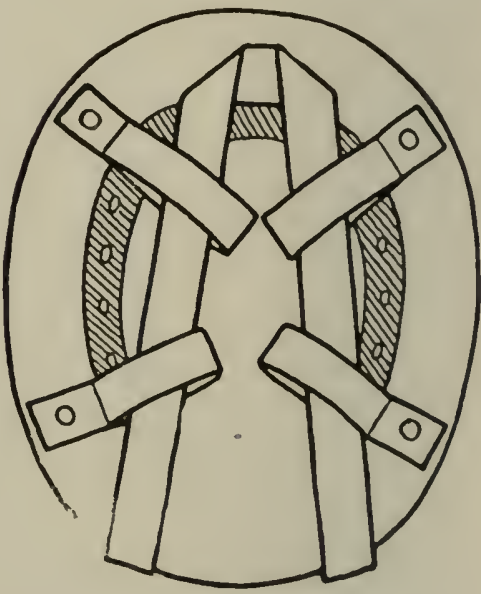

FIG. $8(b)-$ HOME-MADE HORSE-BOOT

it should also be equip rows of various widths, and it should also be equipped with a device to indicate

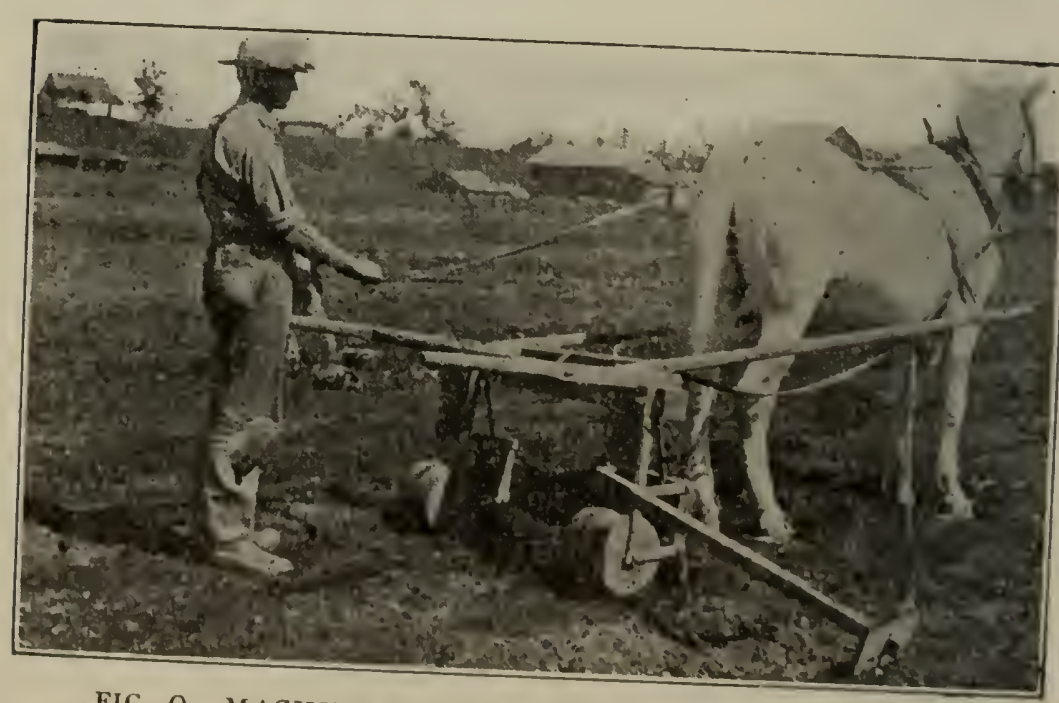

FIG. 9-MACHINE FOB M-IRKING DISTANCES TC PLANT 
where the next row is to be run. A general idea of this machine is shown in Fig. 9. The wheelbarrow marker is a modification of the above, in which the roller replaces the wheel of an ordinary wheelbarrow, and the marking is accomplished by simply pushing the machine across the field. The horsedrawn machine has the advantage that it can be weighted in order to thoroughly compact the soil where the plants are to be set, this being especially desirable at times when the soil is loose and dry. 


\section{CHAPTER IV}

\section{Fertilizers}

By no method known to chemical science is it possible to determine the crop-producing capacity of a soil or to ascertain what should be applied in order to increase the yield. Analysis will show the total amounts of each of the elements necessary to plant growth present in a soil, but the plant alone can cliscriminate between the available and the non-available. Those that are available as plant foods are generally spoken of as soluble in water and those not available as insoluble. The insoluble ingredients act as a reserve and are slowly made available for the use of plants by the action of carbonic acid. The determination of what is lacking in any soil must be made by the application of various kinds and quantities of fertilizers, and the results recorded by the growth of plants.

Natural Fertility of Soils.-The natural fertility of most soils is sufficient for the production of from 20 to 200 crops if it be rendered available. Fertilizers are used on soils of this character to insure the production of a crop and also to aid in the transformation of the latent soil fertility. The liberation of the plant food locked up in the soil can generally be greatly promoted by drainage, the addition of humus, special tillage, or the application of some disintegrating material such as lime. 
In the culture of field crops where the net returns to the acre are small, heavy applications of fertilizers would not prove profitable. Where intensive cultivation is practiced, it is found profitable, owing to the greater returns to the acre, to supply large quantities of fertilizing materials. The celery plant is a gross feeder, and there is perhaps no other crop that will give so large a return for the liberal use of fertilizers.

\section{Chemical Elements Required in Fertilizers.-} Many of the chemical elements of the soil required by plants are abundantly supplied by nature, but nitrogen, phosphorus, potassium, and calcium are often deficient or if present in sufficient quantities are not in an available form. The character and composition of soils are so variable it would be impossible to give a formula for a celery fertilizer that would meet all requirements. Such being the case, all that can be given in a work of this kind is to describe the mixtures used by successful growers, and show wherein lies the fertilizing values of the ingredients of these mixtures.

Sources of Nitrogen.-The celery plant, from its nature of growth, requires an abundance of nitrogen. The principal sources of nitrogen for use as fertilizers are barnyard or stable manure, nitrate of soda, sulphate of ammonia, dried blood, meat scrap or meat meal, tankage, dried fish, fish scrap, cottonseed meal, bone meal, and nitrogenous guanos. Nitrogen from different sources does not give equal results; for instance, that contained in nitrate of soda, fish scrap, and the nitrogenous 
guanos is in a very soluble state and is quickly available. The nitrogen in sulphate of ammonia, bone meal, and fresh stable manure acts more slowly and its influence extends over a longer period.

Sources of Phosphorus.-This element is not found in nature except in combination; calcium phosphate is the usual form. The principal sources of this phosphate are the phosphate rocks of South Carolina, Florida and Tennessee, bones, guano, and stable manure. If bones are ground very finely they become soluble to a limited degree. Phosphate rock, however, as mined is very slowly available. It is therefore treated with sulphuric acicl, which converts part of the phosphate into a more soluble form which for the most part is immediately available to plants. The untreated calcium phosphate when ground very finely is sold under the name of floats, in which form its application to the soil gives a slow but lasting effect. For celery pure raw bone is perhaps the best form of calcium phosphate, but its availability depends largely upon how finely it is ground.

Sources of Potassium.-This element is commonly found in the potash salts known as sulphate of potash, muriate of potash, and kainit. Large quantities of potash are also secured in the form of wood-ashes. Stable manure contains a considerable amount. Most of the heavicr soils contain plenty of potash, but in a form that is slowly available for plants to feed upon. Humic, and light soils generally, are deficient in potash owing to their leaching qualities. Potash is one of the cheapest 
of fertilizing materials and is always safe to apply liberally. Care should be exercised, however, to have it well worked into the soil or injury to the plants may result.

Sources of Calcium.-The principal sources of this element as employed for fertilizers are limestone, oyster shells, marl, and phosphate rock. Limestone and oyster shells are sometimes ground and applied as a fertilizer, but the usual method is to convert the calcium carbonate of the limestone or shells into calcium oxide or quicklime by burning. In the form of quicklime the calcium is more active in correcting the acidity of soils than in any other form. Lime has both a chemical and a physical effect upon soils. Heavy clay soils are loosened and made tillable by the application of lime, but light soils are rendered more adhesive and retentive of moisture by its addition. The chemical effect of lime upon any soil is to assist in the solution of potash and other plant foods, and prepare them for absorption by the roots. Lime also aids the bacteria to change the nitrogen in the soil from the nitrite or insoluble form to the nitrate or soluble form.

Common Salt as a Fertilizer.-Many growers insist upon using salt on their celery land, but its value as a fertilizer is cloubtful, though it is a fact that celery will assimilate a small amount of salt from the soil, thus gaining a decidedly saline flavor, quite pleasant to the taste. The salt, owing to its chemical composition, has a hygienic influence upon the soil and may assist in the prevention of con- 
ditions favorable to the development of plant discases. Salt has an affinity for water and its presence in a soil has a tendency to maintain the proper moisture content, which will be very beneficial during a dry scason. A few hundred pounds of salt applied to each acre will not add greatly to the expense for fertilizers, and will at least assist in the control of any acid that may form in the soil. The salt should be applied at least a month before planting or injury to the plants may result.

Barnyard or Stable Manure.-Barnyard manure may include that from all farm animals. Stable manure as a rule consists of the waste from work animals only, or at most that from work animals and cows. Manure from grain-fed animals is always to be preferred, but extreme care is necessary to avoid the introduction of weed seeds with the manure. Street sweepings and manure containing sawdust or shavings as bedding should never be used on land intended for planting to celery. The ultimate value of stable manure depends very much upon the handling; unless properly cared for and applied it will be almost worthless as a fertilizer. The fertilizing ingredients of a ton of stable manure are worth about $\$ 2.50$ when calculated at the rate charged for them in the chemical form, but as they are not readily available in the manure their value is only about one-half as much, or $\$ 1.25$ a ton.

Aside from its chemical value, stable manure has a physical effect upon most soils which is very beneficial to crop production. When applied to 
sandy or open soils, stable manure serves to bind them together and assists in the retention of moisture. On being applied to heavy clay soils the manure lightens the soil and improves cultural conditions. There are very few soils not greatly improved by liberal applications of stable manures, especially if the manure is first composted and applied to the land in a partially decomposed state. In this way its real value may be as high as $\$ 2.50$ or $\$ 3$ a ton.

The claim has been made by some celery growers that heavy applications of manure to peat or muck lands has a tendency to produce blight. Where these cases have come under observation the trouble has proved to be a firing of the foliage, probably caused by the decomposition of the fresh manure which has been applied in large quantities shortly before planting the crop. The manure should be plowed under in the autumn, or composted under shelter during the winter and spread upon the land early in the spring. If an early crop of peas or beans is grown on the celery land, the manure may be first turned under and again brought to the surface when the soil is re-plowed for planting the celery crop. If the manure is thoroughly composted before spreading it may be applied after the final plowing and harrowed into the soil.

For the production of a home supply of celery there is no fertilizer so efficient as well rotted barnyard manure. The objections to the extensive use of manure in commercial celery growing are the 
labor required to haul and apply it and the slowness of its action.

Manure from Fowls.-The manure from fowls is valuable as fertilizer, often worth $\$ 7.50$ a ton when its fertilizing ingredients are reckoned at market value. Since the elements contained in the manure from fowls are in an available form, this kind of fertilizer should be applied but a short time before planting, or as a top dressing, and worked into the soil between the rows.

Fish Refuse.-Dried fish and fish scrap are among the more valuable sources of available nitrogen and phosphoric acid. Fish guano is made either from unmarketable fish or the refuse from fishcleaning establishments and fish oil factories. When dried and pulverized this guano contains from 6 to ro per cent. nitrogen and from 5 to 8 per cent. available phosphoric acid, but practically no potash. By the addition of 100 pounds of high grade muriate of potash for every 400 pounds of fish guano there will be produced a high grade fertilizer and one that will act quickly. The crude refuse from fish factories or oil mills may be applied directly to the land in the same manner as barnyard manure, but should always be accompanied or followed by an application of potash in some form. For every $\mathrm{r}, 200$ pounds of fish scrap add 800 pounds of unleached wood-ashes to form a complete celery fertilizer; the fish scrap should be applied at the rate of from 3 to 5 tons, and 2 to 3 tons of wood-ashes to the acre. The scrap from the fish factories will require some time for decomposi- 
tion and the wood-ashes or other form of potash should not be applied until later.

Peruvian Guanos.-The Peruvian guanos are especially desirable as fertilizers for celery land, owing to their availability. The better grades of the guanos, however, have become almost exhausted and many of those now upon the market are comparatively low in fertilizing values.

Night Soil and Sewage as Fertilizers.-These waste products have considerable value as fertilizers while fresh, but their use in this form is too offensive to be permissible, especially on land devoted to a salad crop like celery. When decomposed, night soil has very little fertilizing value, unless it has been thoroughly composted with peat or muck. At present a vigorous campaign is being carried on in opposition to the use of objectionable fertilizers in growing garden crops, as there is a possibility of diseases being transmitted thereby. It is reasonably safe to assume that the composition and flavor of such plants as celery may be easily influenced by the character of the fertilizers All organic manures should be well decomposed before applying and thoroughly incorporated with the soil before planting time. The only safe course is to abstain from the employment of night soil, sewage, and similar offensive fertilizers on celcry land.

The Application of Fertilizers.-As a rule the higher grades of fertilizers are more economical to use than the cheaper kinds, owing chiefly to the saving in freight and subsequent handling. None of the materials used in the preparation of fertil- 
izers are pure, and as a rule those containing the higher percentages of the essential ingredients will give the best results with a minimum amount of labor and cost. In order to provide the requirerl weight without increasing the percentages of low grade fertilizers it is often necessary to add a filler consisting of ground rock, ground shells, or dry carth. The filler itself has very little fertilizing value, and its use entails considerable additional cost for freight and handling. It has been shown that celery requires an abundance of all forms of plant food, and for this reason a high grade. complete fertilizer should be employed. A "complete" fertilizer contains all three elements, potash, phosphoric acid, and nitrogen. To determine the value of a ready-mixed fertilizer from the suaranteed analysis printed upon the bags, multiply the percentages given by 20 to determine the number of pounds of each in a ton, and multiply the product by the current price of the clement a pound. For instance, if we have the following:

Nitrogen . . 4 per cent. $\times 20=80$ pounds in a ton at 15 cents $=\$ 12$ Phosphoric acid 6 percent. $\times 20=120$ pounds in a ton at 5 cents $=6$ l'otash . . 5 percent. $\times 20=100$ pounds in a ton at 5 cents $=5$

Total actual valuc .... . $\$ 23$

The price usually charged by dealers for this class of fertilizer is about $\$ 28$, and freight charges must be added in any case. As a rule the higher the grade of fertilizer the lower will be the difference of ratio 
between the actual value of fertilizing ingredients and the cost of the ready-mixed article.

Cost of Fertilizers for an Acre.-The amount of fertilizer applied an acre varies greatly in different localities. It is difficult to state the quantities applied in so many pounds, and such statement would mean little owing to the great variation in the composition of different brands of similar formulas. The grower is inclined to figure closely upon the cost of producing a crop and prospective growers will appreciate the quantity of fertilizers necessary if expressed in dollars rather than in pounds to the acre. The celery growers in Florida apply as much as $\$ 150$ or $\$ 160$ worth of fertilizing materials to each acre uncler cultivation every year the land is planted. This is applied in the form of 20 to 40 cart-loads of barnyard manure, preferably rotted cow manure, plowed under; two tons of high grade complete fertilizer, one ton broadcast and worked into the soil and one ton drilled under the rows; $I, 000$ pounds of nitrate of soda applied in three or four top dressings during the growing period. Occasionally wood-ashes are substituted for a portion of the high gratie fertilizer. During the time the land is not occupied with the celery it is often planterl to cowpeas and the crop turned under for green manure. The soil is given a dressing of lime every thrce years, except when wood-ashes are extensively used. The ashes take the place of the liming to a great extent.

In the northern and western celery fields it is unusual to find the growers applying so large 
quantities of fertilizers. Many do not apply more than $\$ 30$ worth an acre each year, but this is a serious mistake and a heavier application would prove profitable. Twenty tons of barnyard manure an acre every two or three years, and $I$ to 2 tons of high-grade fertilizers every year will produce good results. The land should be planted to some renovating crop once in four years, and if this crop is turned under to serve as green manure the application of 30 to 40 bushels of quicklime to the acre should follow in order to sweeten the soil. If barnyard manure is not available for use in growing the home supply of celery, it will be well to secure a good grade of commercial fertilizer that contains about 8 per cent. nitrogen, 6 per cent. phosphoric acid, and 8 per cent. potash, and apply a little more than two quarts to each rod ( $161 / 2$ feet) of row to be planted, working the fertilizer into a strip of soil I 2 to 18 inches in width. The fertilizer should be applied to the soil several days before setting out the plants.

Time for Applying Fertilizers.-The time for applying fertilizers depends entirely upon the character of the soil and the solubility of the fertilizer. On porous soils it would not be advisable to apply high-grade fertilizers very much in advance of planting, but on retentive soils an early application may be made with safety. It is always best to apply barnyard or stable manure some time in advance of planting, a whole year not being too long in many cases. As a rule bone meal, untreated phosphate rock, and all slowly available ingredients 
should be applied three to six months before planting time. A desirable fertilizer and crop rotation scheme for celery land in the northern states would be to begin by applying 20 to 30 tons of barnyard manure an acre in the spring, plant to corn during the summer, as soon as the corn is harvested sow the land with rye, without plowing, at the same time applying 2,000 pounds fresh lime or $\mathrm{I}, 000$ pounds ground bone to the acre. The rye is intended merely to serve as a cover crop during the winter and should be plowed under before it makes any appreciable growth in the spring. While fitting the land in the spring, apply $\mathrm{I}, 000$ pounds of high-grade fertilizer broadcast or by means of a fertilizer distributer or grain drill, and later an additional $\mathrm{I}, \mathrm{OOO}$ pounds can be worked into the celery rows before the plants are set. Also apply 300 to 600 pounds of nitrate of soda in two or three top dressings during the growing season, the first being applied four or five weeks after planting. The following three years the celery will occupy the land until quite late in the autumn and the plowing can not be done until early spring. As soon as the land is in shape to work, plow and then apply I,OOO pounds of finely ground bone, and later apply the high-grade fertilizers as before. Repeat. every fourth year with corn preceded by a heavy dressing of manure to maintain the humus in the soil. On muck lands the manuring will not be necessary oftener than every six or eight years, but on sandy loams and glade lands the process should be repeated every fourth year, and a limited amount 
of rotted manure may be applied every year if available.

In Florida and other localities where the celery crop is matured during the winter months, it will be necessary to apply the manure during the late winter or in summer, and an early spring crop of tomatoes or cucumbers may be grown on the land. The commercial fertilizers are then applied while preparing the land for celery in the autumn.

Home Mixing of Fertilizers.-In the selection of fertilizers it is desirable to know the form of each of the elements as well as the percentage contained. Nitrogen obtained in the form of nitrate of soda will act more quickly than that obtained from sulphate of ammonia; phosphoric acid from dissolved bone is more available than the phosphate contained in ground raw bone. Nitrate of soda should be used frequently, but in small quantities, as a top dressing after the celery plants are well established in field or garden. Sulphate of ammonia, cottonseed meal and bone sliould be applied before planting and thoroughly intermixed with the surface soil. By purchasing the ingredients and mixing together in the proper proportions it is possible to save from $\$ 2.50$ to $\$ 7.50$ a ton, and at the same time secure the elements in the desired form. The table on pages 32 and 33 gives the percentages of the elements usually present in the several fertilizing ingredients, together with their customary prices a pound for the element itself and the value a ton of the ingredicnts containing it.

Soils of different character require a variation in 
the composition of fertilizers and the formula best suited to any soil must be determined by careful tests. The assumption may be safely made, however, that muck or peat soils are as a rule rich in latent nitrogen and deficient in phosphoric acid and potash. On soils of this character it would be economical to apply a fertilizer of about the following composition: 200 pounds sulphate of ammonia, containing 25 per cent. ammonia; I,O0O pounds high-grade acid phosphate, containing $i 6$ per cent. available phosphoric acid: 500 pounds muriate of potash, containing 40 per cent. actual potash. This gives a fertilizer containing about 3 per cent. nitrogen, 9 per cent. available phospohric acid, and II.7 per cent. potash. A still simpler mixture would consist of : 350 pounds dissolved bone, containing 2 to 3 per cent. nitrogen and 15 per cent. available phosphoric acid; I50 pounds muriate of potash, containing 40 per cent. actual potash. This will give a fertilizer containing from $\mathrm{I} / 2$ to 2 per cent. nitrogen, I0.5 per cent. available phosphoric acid, and 12 per cent. potash.

On clay or sandy soils the nitrogen is nearly always deficient and the phosphoric acid and potash more abundant. On very porous soils the potash is generally present in limited quantities only. For clay and sandy soils that are not badly leached the following formula is suggested: 200 pounds sulphate of ammonia, containing 25 per cent. ammonia : 400 pounds dissolved bone, containing 2 to 3 per cent. ammonia and 16 per cent. available phosphoric acid: 300 pounds high grade blood and bone, con- 
taining Io per cent. ammonia; IoO pounds muriate of potash, containing 50 per cent. actual potash. This will contain about 9 per cent. nitrogen, 6.4 per cent. available phosphoric acid, and 5 per cent. potash.

Or this formula may be used: 100 pounds nitrate of soda, containing it per cent. ammonia, or I4 per cent. nitrogen; 500 pounds sulphate of ammonia, containing 25 per cent. ammonia; 400 pounds high-grade blood and borıe, containing ro to II per cent. ammonia; 800 pounds high-grade acid phosphate, containing 16 per cent. phosphoric acid; 200 pounds sulphate of potash, containing 50 per cent. potash. This will contain about 9 per cent. nitrogen, 6.4 per cent. phosphoric acid, and 5 per cent. potash.

For soils that are badly leached the potash content should be higher, and the following are suggested: 600 pounds sulphate of ammonia, containing 25 per cent. ammonia; 200 pounds high-grade blood and bone, containing Io or I $\mathrm{I}$ per cent. ammonia; 800 pounds dissolved bone, containing 2 to 3 per cent. ammonia, and 16 per cent. available phosphoric acid; 400 pounds muriate of potash, containing 50 per cent. potash. This contains about 9.5 per cent. nitrogen, 6 per cent. available phosphoric acid, and ro per cent. potash.

Or this formula may be used: 500 pounds sulphate of ammonia, containing 25 per cent. ammonia: 400 pounds high-grade blood and bone, containing Io per cent. ammonia; 700 pounds high-grade acid phosphate, containing 16 per cent. phosphoric acid: 
400 pounds muriate of potash, containing 50 per cent. potash. This gives 8.25 per cent. nitrogen, 5.6 per cent. available phosphoric acid, and io per cent. potash.

Each of the above formulae is based upon the supposition that liberal dressings of nitrate of soda will be applied during the growing season. Nitrate of soda should not be stored in bags or in a damp) place. The bags from which the nitrate of soda has been emptied should not be thrown in a heap, as spontaneous combustion may result. One point which should be borne in mind is that any mixture should not contain large quantities of both nitrate of soda and muriate of potash, as these ingredients are both inclined to draw moisture and render the whole mixture difficult to handle.

In mixing fertilizer ingredients great care should be taken. that the work is thoroughly performed. The usual method on the farm is to dump the ingredients together in the right proportions upon a floor and then mix by shoveling over several times. Screening or sifting will assist in securing a uniform mixture.

When mixing the highly-concentrated fertilizer ingredients it is often advisable to employ a filler in order to increase the bulk and secure a dry combination that may be easily handled. Materials suitable for this purpose are often difficult to obtain and should be provided and stored in a dry place until used. Road dust, peat, light sandy soil, sifted coal ashes, leached wood-ashes, ground shells, ground limestone, tobacco dust, gypsum or land 


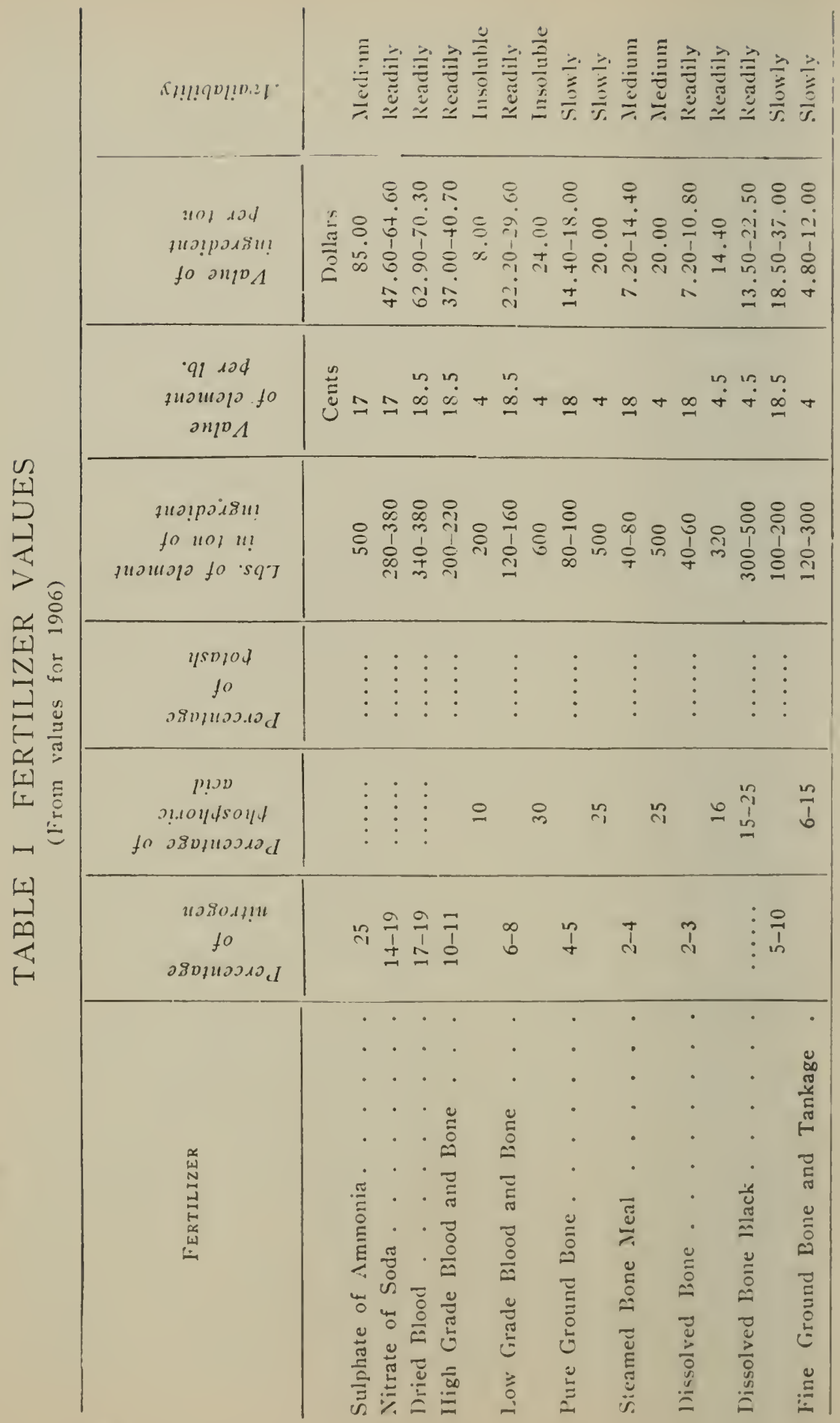


भ $\quad$ 요

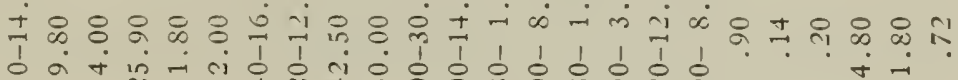
I

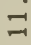
$\pm \therefore \quad$ in

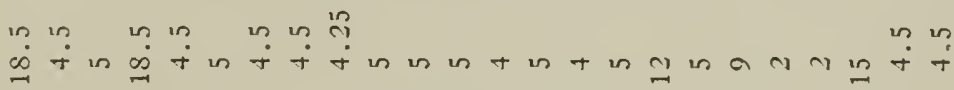

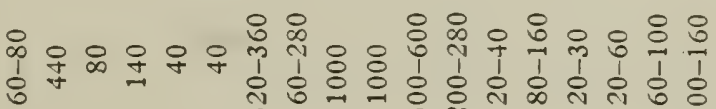

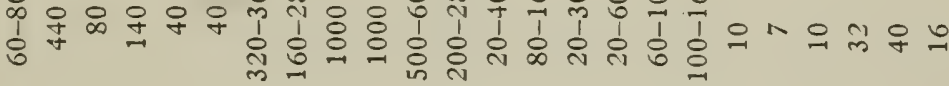

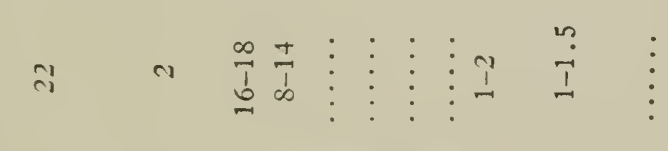

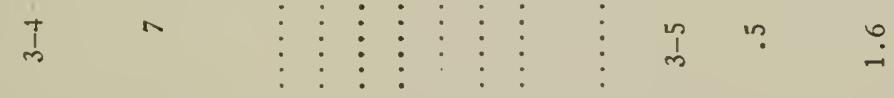

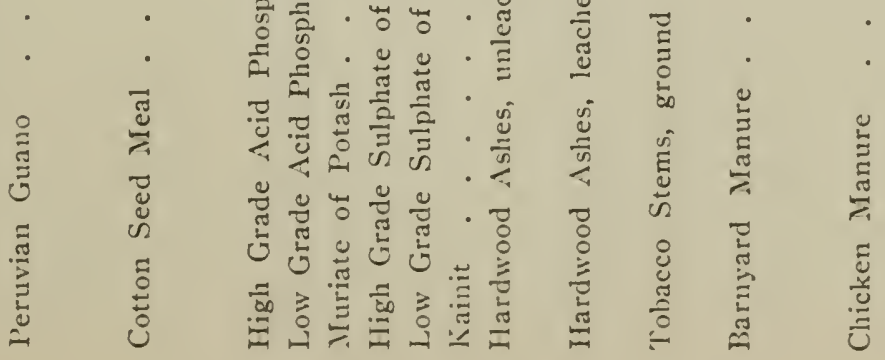


plaster, and low grade acid phosphate may be used as fillers. A number of the above contain considerable fertilizing value in themselves, but as a rule this should not be considered in computing the value of the mixture. 


\section{CHAPTER V}

\section{The Production of Plants}

In order to produce a satisfactory crop of celery it is essential to first secure good plants. Many of the reported failures in celery growing can be traced directly to careless methods of handling the plants. In the first place good seed is essential, but it can be procured from any reliable seedsman, and the price paid should be such that the dealer will be justified in furnishing the best that the seed market affords. Celery seed is practically worthless when more than one year old, and if for any reason it is desirable to keep seed from one year to another it should be enclosed in a close-fitting tin box, or sealed in a fruit jar, and stored where it will be free from changes of temperature and humidity. A large percentage of celery seed will germinate the second season, or even after a number of years, but the plants so produced will lack vigor and be more liable to the attacks of disease than those from fresh seed. Owing to the minute size of celery seed, an ounce or two will be sufficient for the small market gardener, and a packet will produce all the plants required for the home garden. European-grown celery seed is preferred by most gardeners, especially of the selfblanching sorts, although there are a number of 
seed growers in this country who are producing high-grade seed.

In many localities celery production is naturally divided into the early or small crop, and the later or main crop. For the early crop in the North it will be necessary to start the plants indoors, eit'ner in the house, greenhouse, hotbed, or cold-frame.

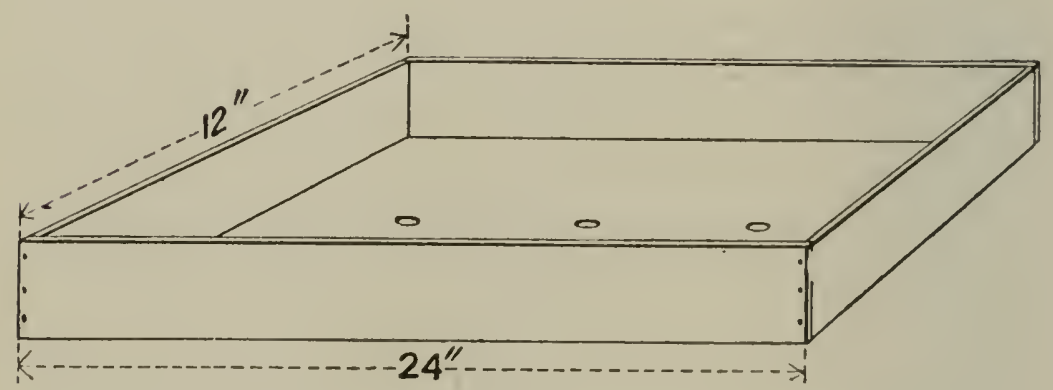

FIG. IO-TRAY FOR SEED SOWING OR TRANSPLANTING

For the later or main! crop the seed can be sown in cold-frames, especially prepared beds, or in the open ground.

Starting Plants in a Window Box.-For sowing a small quantity of seed in the house, provide a sluallow box or tray, as illustrated in Fig. 10, bore two or three holes in the bottom to insure drainage. fill with soil consisting of two parts of good garden loam, one part of well-rotted stable manure, and one part of leaf mold or sand. The different ingredients should be well mixed together and then sifted through a sieve having one-fourth-inch meshes. Fill the tray a little more than level full and then 
stroke off even with the top and firm the soil slightly by means of a small piece of smooth board. Mark off drills $1 / 4$ inch in depth and 2 inches apart and scatter the seeds very thinly in these. After the seeds are distributed, place a little leaf mold or other fane soil in the sieve and sift lightly over the seeds. The covering should be very light, not more than $1 / 8$ inch deep. After the covering is sifted on, the soil should again be slightly firmed and moistened. The tray is then ready to set near a window in a room where a living temperature is maintained and where care can be taken that the soil is moistcned as often as it shows indications of dryness.

The seeds will generally germinate in about 14 days, and as soon as the seedlings appear the tray must be kept where there is plenty of light. If the plants are started in an ordinary window it may be necessary to turn the box each day to prevent their becoming drawn toward the light. In three weeks after the plants appear, or when they have formed two or three leaves in addition to the seedleaves, they can be pricked out or transplanted to other boxes or into a cold-frame and given about 2 inches space in each direction for their development.

Starting Plants in Greenhouse or Hotbed.Where a considerable number of extra early plants are desired, it will be necessary to sow the seed in a greenhouse bench or in a hotbed. If sown in a greenhouse bench the location should be in a rather cool part of the house and where the plants will 
receive an abundance of sunlight. The young celery plants will thrive in a night temperature of from 55 to $65^{\circ} \mathrm{F}$. and 65 to $75^{\circ}$ during the day.

Construction and Care of Hotbeds.-There are a number of forms of hotbed, the essential being an enclosure covered with sash and supplied with some form of heat, usually fermenting stable manure, to keep the plants warm and in a growing condition. The hotbed should always face to the south, and the south side of either a dwelling, barn, tight board fence, hedge, or anything affording similar protection, will furnish a good location. In the North the hotbed should be started during the last of February or early in March, but the seed should not be sown until the bed has attained an even temperature. The manure-heated hotbed will become quite hot at first and should be made long enough to permit the temperature to become uniform before sowing the seed. There are two or three forms of hotbeds that are worthy of description, and the plans suggested may be modified to suit local conditions.

Temporary Hotbeds.-A temporary hotbed is easily constructed by the use of manure from the horse stable as a means of furnishing the heat. Select a well-drained location, shake out the manure into a broad, flat heap, and thoroughly compact it by tramping. The manure heap should be 8 to 9 feet wide, 18 to 30 inches deep when compacted, and of any desired length, according to the number of sash to be employed. The manure employed 
in making a hotbed should contain sufficient litter, preferably leaves or straw, to cause it to spring slightly under the feet when being compacted.

After the manure has been properly tramperl and leveled, the frames to support the sash are placed in position facing toward the south. These frames are generally made to carry four standard hotbed sash, and the front board should be 4 to 6

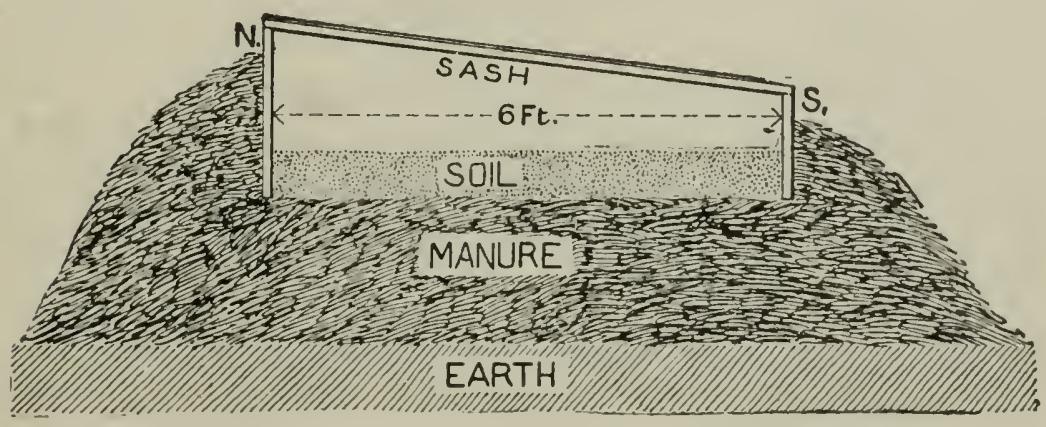

FIG. II-CROSS-SECTION OF TEMPORARY HOTBED

inches lower than the back, in order that water will drain from the glass. When the frame is in position the manure is banked up around the outside, and about 4 inches of good garden loam is spread evenly over the enclosed space. Sifted soil as indicated for use in window tray is then spread to a depth of 2 inches on top of the garden loam, the sash placed in position and the bed allowed to become warm. When completed the temporary hotbed will appear as shown in Fig. II.

Permanent Hotbeds.-Hotbeds having more or less permanence may be so constructed as to be heated with fermenting manure, a stove, a brick 
Alue, or by means of radiating pipes supplied with steam or hot water from a dwelling or other heating plant. For a permanent bed in which fermenting manure is to supply the heat a pit 24 to 36 inches in depth should be provided. Connecting to the bottom of the pit there should be a drain to prevent the accumulation of water during a rainy

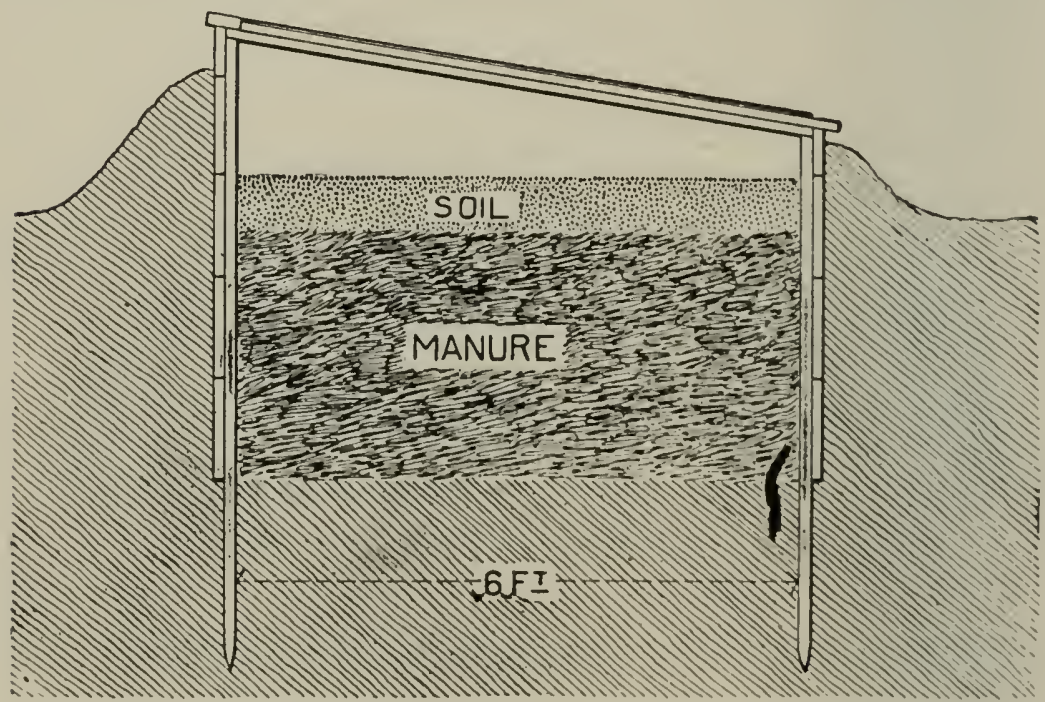

FIG. I2-CROSS-SECTION OF PERMANENT HOTBED

season. The sides and ends of the pit should be supported by a lining of boards, brick, concrete. or stone, but two-inch planks are most commonly used. For illustration of permanent hotbed construction see Fig. I2.

Coverings for Hotbeds.-Standard hotbed sash are $3 \times 6$ feet in size, and are usually constructed of white pine or cypress. As a rule, hotbed sash can be purchased cheaper than they can be made 
locally, and are on sale by dealers in garden supplies. In the colder parts of the country, in addition to glazed sash, either board shutters, straw mats, burlap, or old carpet will be required as a covering during cold nights. It is also desirable to have a supply of straw or loose manure on hand to throw over the bed in case of extremely cold weather.

Ventilating and Watering the Hotbed.-During bright days the hotbed will heat very quickly from the sunshine on the glass, and it will be necessary to ventilate during the early morning by slightly raising the sash on the opposite side from the wind. Toward evening the sash should be closed in order that the bed may become sufficiently warm before nightfall. Hotbeds should be watered on bright days and in the morning only. Watering in the evening or on cloudy days will have a tendency to chill the bed and increase the danger from freezing. After watering. the bed should be well ventilated to dry the foliage of the plants and the surface of the soil, to prevent the plants being lost from damping-off fungi.

Construction, Care, and Uses of Cold-frames.The use of the cold-frame is of more importance to the celery grower than the hotbed. In the North the cold-frame is used as a transplanting bed for the early crop plants that are started in the hotbed. The cold-frame is also desirable as a seed-bed for the later crop plants. 'Toward the southern limits of the northern celery growing belt the cold-frame takes the place of the hotbed for early seed-bed 
purposes. The construction of cold-frames is the same as for temporary hotbeds, except that no manure or other heating material is provided. Coldframes are covered by means of ordinary hotbed sash, but white cotton cloth or light canvas may be substituted for the sash. The same methods of handling recommended for a hotbed apply to a cold-frame and thorough ventilation should be maintained on bright days. Plants grown under glass must be gradually hardened before time for plant-

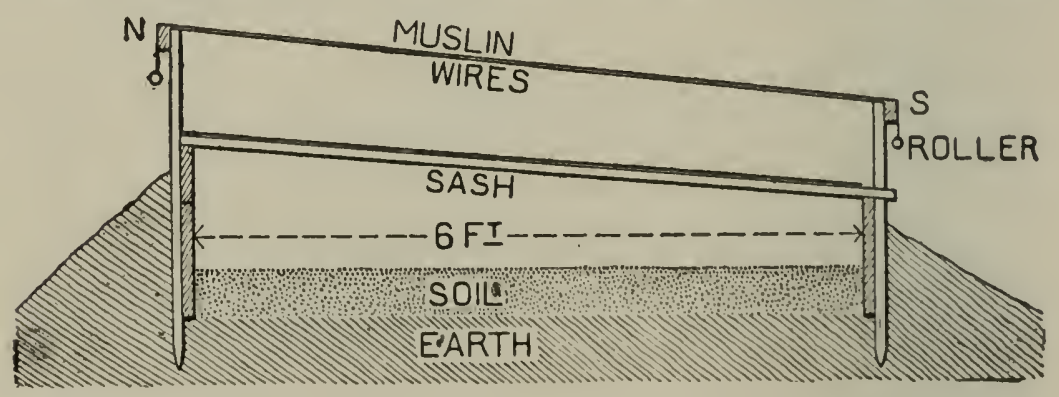

FIG. I3-CROSS-SECTION OF COLD-FRAME WITH MUSLIN SHADE

ing in the garden or field. Hardening is accomplished by increasing the amount of ventilation and exposure to sun and wind from day to day, until finally the covering may be left off entirely, but should be kept ready for use in case of severe cold or frosting. The partial withholding of water will assist in the hardening process, but great care should be taken that the plants do not become severely checked in their growth. The object should be to produce a thrifty plant, well acclimated, and ready to withstand the shock of transplanting.

Sterilization of Soil for Seed-bed.-Weeds are 
difficult to control in the seed-bed, and where the necessary facilities are available the seeds can be destroyed by sterilization. On a small scale, as in preparing the window tray, place the soil in a shallow pan and bake for two hours in an oven at about the proper temperature for baking bread. On a larger scale, soil sterilization can be accomplished by discharging live steam from a boiler directly into the soil. The usual method of steam sterilization is to first prepare and sift the soil, then shovel it into a box, having a coil of perforated pipe in the bottom. When the box has been filled and covered the steam is turned on for several hours. The usual test to determine when sterilization has been carried far enough is to place a medium-sized Irish potato in the soil near the central top part and apply the steam until the potato is thoroughly cooked. Practically the same results may be accomplished by burning a quantity of brush upon the ground intended for seed-bed purposes. Sterilization not only destroys weed seeds present in the soil, but insects and fungous diseases as well.

Starting Plants in the Open Ground.-When it is desired to secure plants in large numbers for planting the late or main crop, the seed is generally sown in outside beds. The methods of preparing and handling these beds varies according to the character of soil and climatic conditions, but as a rule the land for seedbeds is plowed in the autumn and fertilized with about I5 tons of well-rotted stable manure which is free from weed seeds and I ton of bone 
meal to the acre. As soon as the land can be worked in the spring the surface soil is thrown up into long beds, each 6 or 7 feet in width with a narrow walk between. The walks should be 4 to 6 inches lower than the surface of the beds and be connected with a central ditch in order that they may serve as clrains. Fresh hardwood ashes, at the rate of $I, O O O$ pounds to the acre, and nitrate of soda at the rate of 300 pounds to the acre, may be applied at the time the beds are marle up, but should be well worked into the soil to a depth of 4 inches. After the beds have been raked reasonably smooth, they should be permitted to settle for a day or tivo before seeding.

Just before sowing the seed, the beds should be raked to a clean even surface, and if a seed clrill is cmployed for sowing the seeds, it should be preceded by a light roller, or the soil may be smoothed by drawing a board over it. If the seeds are to be sown broadcast, the steel rake or Meeker harrow will leave the soil in about the proper condition for seeding, and the covering can be accomplished by rolling lightly, firming with a board, or by raking very lightly with a steel rake. Some growers prefer to scatter the seeds over the freshly raked soil and trust to the first watering or shower to cover them sufficiently. The grower must be governed in the matter of covering the seeds by the cliaracter and condition of the soil. but the covering should always be light. Sowing in drills is preferable to broadcasting as the spaces between the rows can be cultivated. 
Care of the Outdoor Seed-bed.-Care is necessary in watering the seed-bed and the rule should be to water only the spots that begin to show a tendency to dryness, althougl no part of the bed should become dry. The best method of applying water to the seed-bed is by means of a sprinkling can in the hands of a competent boy. In case the bed is a large one, the supply of water should be conducted to different parts of the bed by means of pipes, and a half-barrel placed under each outlet in order that the sprinkling can may be filled easily. The beds should be gone over very often during daylight hours and watered only when necessary. About three weeks' time is generally required for celery seed sown in the open ground to appear, and this together with the two weeks following is the most critical period in the production of a celery crop. As soon as the seedlings appear, the watering must be performed with the greatest of care and should not be excessive on account of the liability of "damping-off." The damping-off fungus is not so liable to attack celery plants grown in the open secd-bed as those in the greenhouse or lotbed, but conditions siditable to its development are brought about by rcessive watering and humidity.

Protection of Plant Beds.-In localities subject to strong winds, it is often necessary to protect the plant beds by means of shelters consisting of either a tight board fence on one or more sides of the beds, cotton cloth spread upon the beds before the plants are up and afterward raised and suspended over the beds, or by setting wide boards on edge 


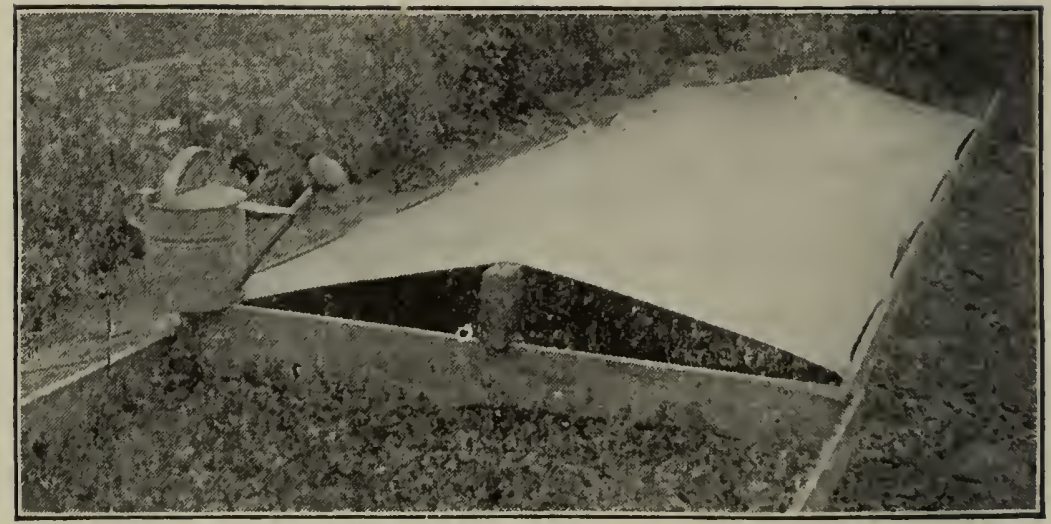

FIG. I4-CLOTH-PROTECTED CELERY PLANT BED FOR HOME GARDEN (By courtesy of Farming)

along the sides of the beds. When the seed-bed is located on muck land, some protection is frequently necessary to prevent the loose soil blowing or shifting, and either coverning the seedlings or blowing the soil from around their roots. In some parts of the country the sunshine is too strong for the young celery seedlings, and it is necessary to provide some form of shading to prevent their being

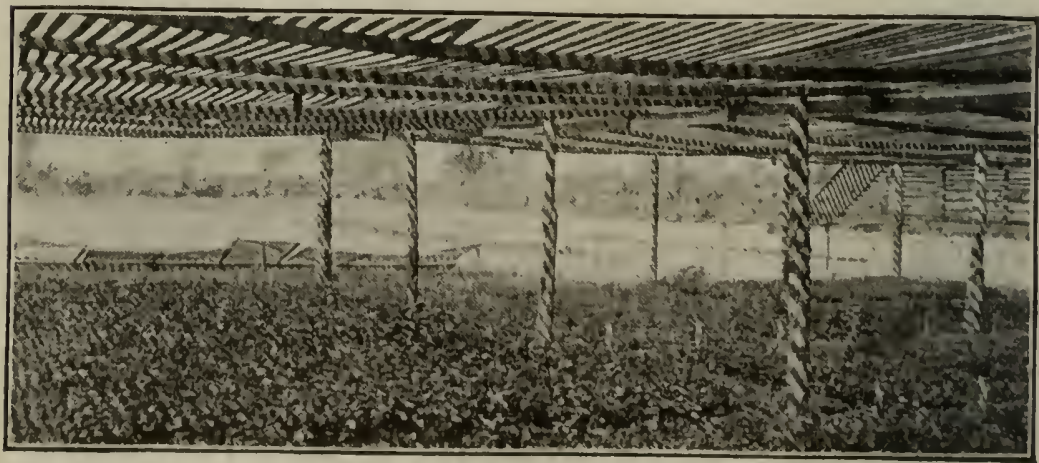

FIG. I5-CELERY PLANT 13ED UNDER SLAT SHADE 
injured. Unbleached cotton, tobacco shading cloth, or wooden lath may be employed for this purpose, but the lath so arranged as to give about one-half shadow and one-half sunshine is most desirable.

Transplanting.-The young plants of celery are greatly benefited by transplanting. So long as the seedlings remain undisturbed in the plant bed they develop a central straight root with few laterals. In transplanting, this straight root becomes broken and as a result a large mass of rootlets are formed which work near the surface and feed the plant. The transplanting process also provides uniform space and development, rendering the plants better able to withstand the setting in the open field or

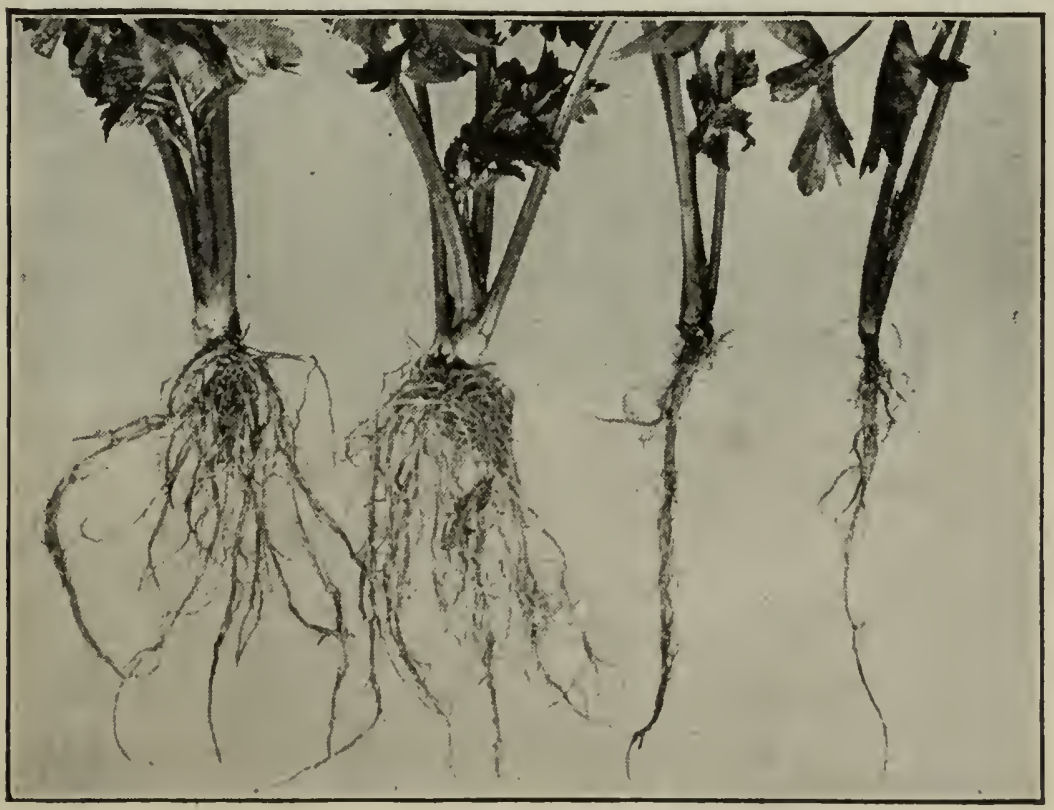

FIG. I6-EFFECT OF TRANSPLANTING UPON THE ROOT SYSTEA OF CELERY PLANTS 
garden. The seedlings should be transplanted as soon as they are large enough to handle, or when they have about three true leaves. The soil in which the seedlings are transplanted should be made quite rich by the addition of well-rotted stable

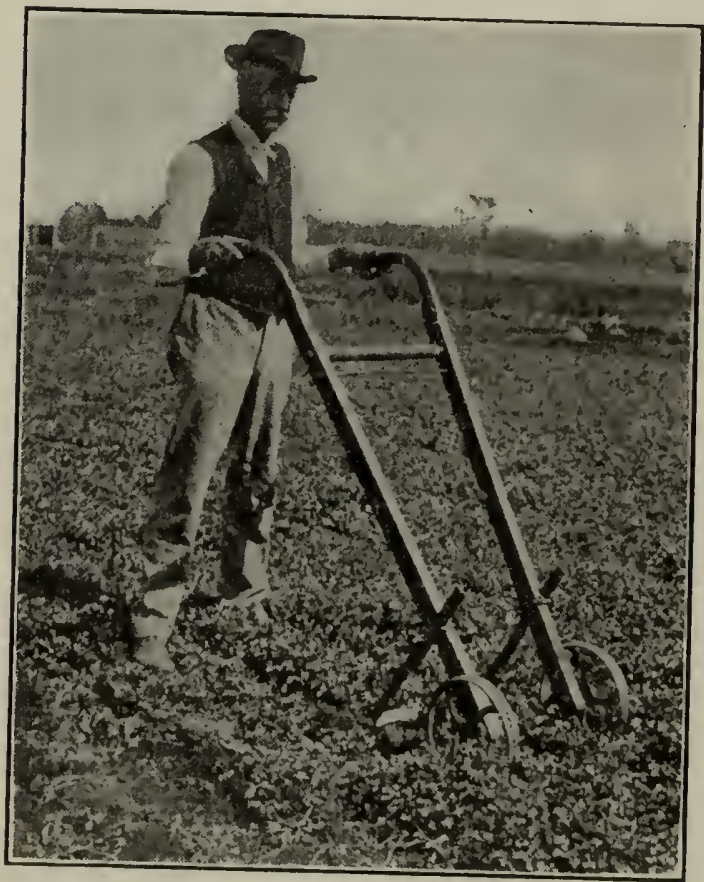

FIG. IT-DEVICE FOR CUTHING RUOTS OF CELERY PLANTS IN SLEID-BED

manure and its condition will be greatly improved by screening.

The effect of transplanting is illustrated in Fig. 16, which shows celery p lat $11 \mathrm{t} \mathrm{s}$ from the same seeding, those on the left having been transplanted when about three weeks old. and those $\mathrm{O} n$ the right having been left in the seed-bed until abont six weeks later, at which time the photo was taken. The transplanting process adds abont $\$$ I a 1,000 to the cost of growing the plants, and is not practical on a large scale. This method of handling will pay well for the early or small crop, but the late crop has more time for its development, and the transplanting process, although desirable, may be dispensed with. 
Substitutes for Transplanting.-As a substitute for transplanting, a number of the northern growers employ a method of cutting under the plants and thus severing the straight root. This root pruning is generally performed ten days or two weeks before the plants are required for setting in the field, and causes numerous fibrous roots to be formed around the remaining portion of the straight root. The work of cutting the roots is executed by means of

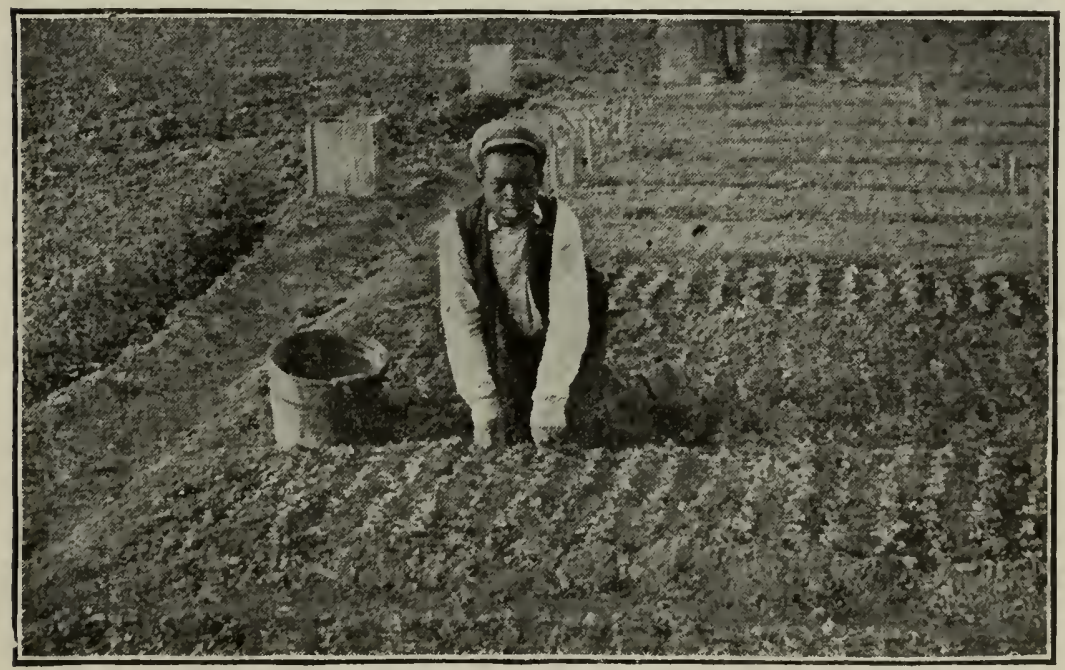

FIG. I8-TRANSPLANTING CELERY PLANTS IN FLORIDA (Photo by P'rof. W. G. Johnson)

some form of blacle that can be run at a depth of about 2 inches below the surface of the soil. One of these cutting devices, as shown in Fig. 17, consists of a sharpened blade mounted on a frame and wheels similar to those of a warehouse truck. The blade can be adjusted to any desired depth and is removable for sharpening. Cutting the 
main root of the plant also aids very materially in lifting the plants at planting time. After cutting, the plants should be well watered to prevent their wilting.

Proper Time to Plant Seed.-From the time the celery seed is sown until the crop is cut for packing, it should be the aim to maintain a steady and healthy growth. The seed-bed should contain sufficient available plant food to last throughout the time it is so occupied, and the plants should not receive a shock or rest at any time during their growth. When celery plants become overgrown or crowded in the seed-bed, or are allowed to remain too long in the transplanting bed before setting in the field or garden, they will undergo a check or rest that will be liable to cause them to run to seed later. Seed sown too early in the louse, greenhouse, or hotbed will produce plants that are liable both to run to seed and to become pithy. In fact any severe check or prolonged period of rest is likely to answer the same purpose in the life history of the plant as wintering over, and it will then produce a seed stalk.

For the early crop in the North, sow the seeds indoors during the first week of March-the seedlings should appear by March 2o-transplant to coldframes or to trays during the first or second week in April, and set in the garden the third week in May. This should produce celery ready for use by the middle of August. For the main or later crop, sow the seeds in cold-frame or protected beds during the first week of April, transplant during the 
early part of May, and set in the open yround from June 15 to 25 . This method should produce marketable celery during the first half of October.

By calculating upon Ioo days in the field, 35 days in the transplanting bed, and 35 days in the seedbed, including time for germination, we have a total of I70 days, and it is an easy matter to determine when the seed should be sown, provided the time for the maturity of the crop is known. In Florida, and similar climates, the seed is sown late in summer and the crop matured during the winter months. The consumption of celery reaches its height during the period beginning with Thanksgiving and ending with February $\mathrm{I}$, and if the crop can be placed on the market during this period the highest prices will be realized. 


\section{Planting in Field and Garden}

In the North, the early crop should be set in the open ground as soon as danger of severe frost is past, or from May ro to June 5. 'The later or main crop plants, should be set from June io to July 5 . In the southern celery-growing belt, plant setting begins in September and continues until January or February, although the main planting is clone during September and October. It is often possible to select a cloudy or rainy time for setting the plants, but if the weather is dry, with no inclications of showers, the plants should be set late in the day in order that they may have the night to recuperate.

Lifting the Plants.-The plant bed should be well watered several hours before the plants are lifted, and as much soil as possible kept on the roots during handling. If transplanted plants are being used, they should be removed from the plant bed by running a knife blade between them in both directions and then lifting with a cube of earth adhering to the roots. If the plants have not been transplanted, they should be loosened by means of a trowel or spade and separated. Among the thriftiest plants in the bed will be found all the rogues, or sports, as they are commonly called, and it has often been observed that where two or three plantings are taken from the same bed, using the best plants each 
time, that the first lot will invariably include those that are not true to variety type.

Broad, flat pans, made of galvanized iron, 3 inches deep and 16 inches in diameter, are suitable for holding the plants while they are being transported from the plant bed and set in the field. If the weather is dry, a layer of wet moss placed in the bottom of each of the pans will aid greatly in keeping the plants in good condition. The work of taking up the plants is generally performed by boys and girls or other cheap labor, but it is essential that the work should be well done, as the speed attained by the planters and the growth of the plants afterward depend largely upon the condition of the plants when set. The pans containing the plants should be either carried or carefully hauled to the fields where the planting is being done, and protected from drying until required for setting. If the plants have made a vigorous growth in the plant bed, it will be advisable to cut back the tops, by means of a lawn mower, scythe, or sickle, in order to reduce the drain upon the roots until the plant becomes established in the open ground.

Packing Celery Plants for Shipment.-Where it is desirable to ship celery plants either by express or freight, they should be packed in a crate similar to that shown in Fig. I9. The bottom portion of the crate should be tight while the top part is made as open as possible for ventilation. Before packing the plants a layer of wet moss is placed in the bottom of the crate and the roots set upon or slightly imbedded in the moss. The plants should 


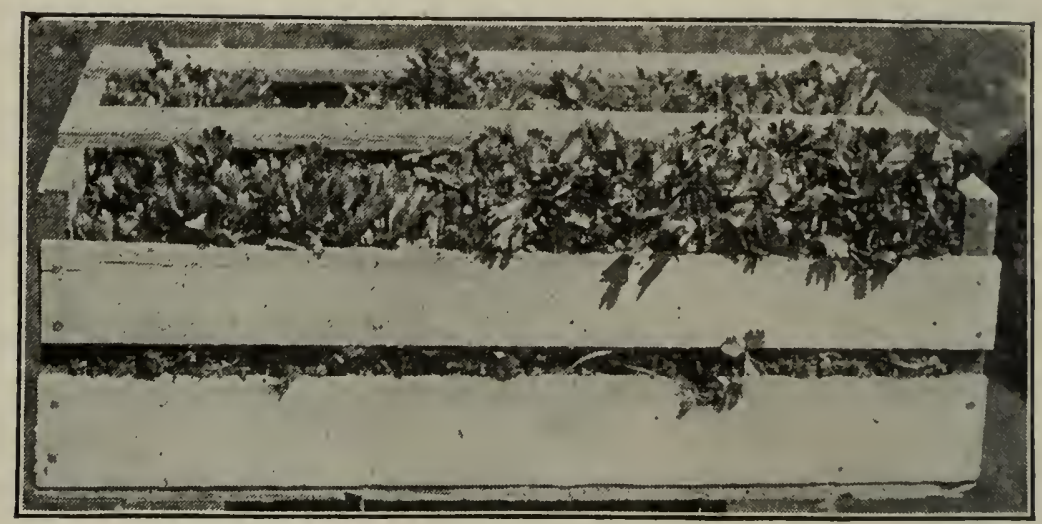

FIG. I9-CRATE OF CELERY PLANTS PACKED FOR SHIPMENT

be kept straight and all placed with their roots in contact with the wet moss. When shipping plants during very warm weather it will be necessary to place two or three strips of wood across the crate to separate the plants and provide additional ventilation. The carriers which hold six of the fourquart cups or baskets such as are employed for shipping fancy peaches, are desirable for transporting celery plants during warm weather, as the air has abundant circulation between the baskets and prevents the plants becoming heated in transit. Thousands of celery plants are lost from heating in transit, and this loss can be avoided by packing in small lots or providing plenty of ventilation spaces.

Setting in the Open Ground.-A short time before planting, the finishing touches should be given the land, either by means of a light harrow, roller, or, best of all, by floating with the drag constructed of square scantlings as shown in Fig. 6. The marker 
should be kept at hand during the entire time of planting and the rows marked as required for setting, in order that the marks may be fresh at the time the plant is set. If possible the rows should run north and south, as this gives sunshine part of the day on each side of the row. The plan of having boys to drop the plants ahead of the planters is not recommended, as the roots become dried more or less before they are set in the soil. The proper method is to have the plants well placed in the pans and a boy on hand to assist the planters and replace the pans as they are emptied. The men who do the planting generally work upon their knees, as shown in Fig. 20, and should be provided with knee pads made of leather and padded with felt. When the plants are set and the soil well pressed down around them, they should be just a little below the general level of the soil, but not low enough to become covered by heavy

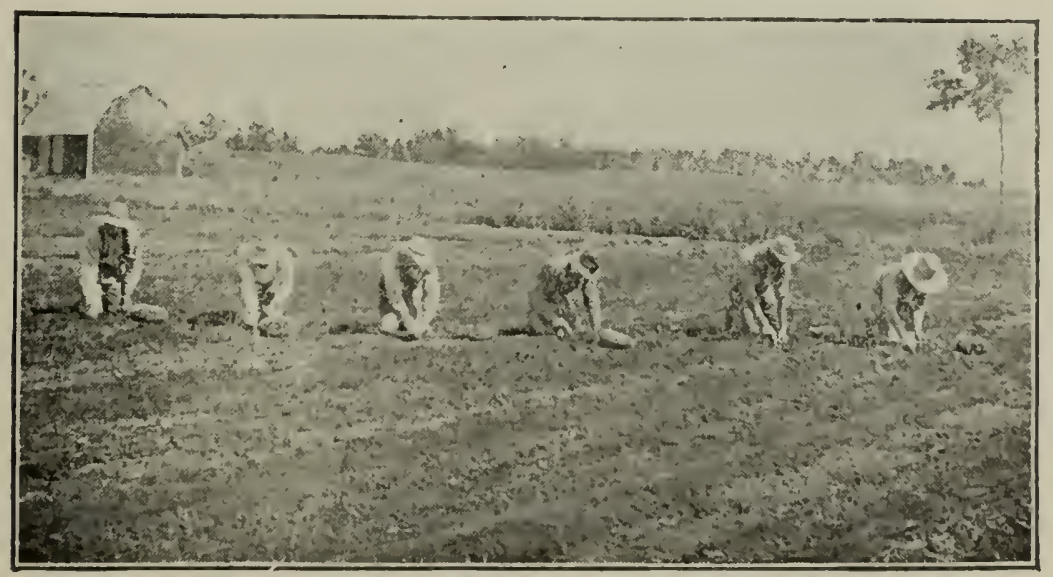

FIG. 20-SETTING CELERY PLANTS IN FIFLLD 
rains. Where the plain, flat shoe marker is used, it may be necessary to employ a dibble for making the holes in which to set the plants, but with the wheel marker as shown in Fig. 9 the work
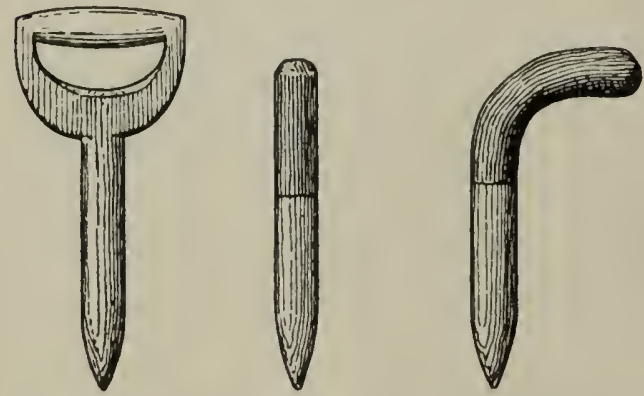

FIG. 2I-DIBBLES FOR USE IN SETTING CELERY PLANTS

ing the crop. Transplanting machines are not practical for setting celery as the plants cannot be handled rapidly enough. The cost of setting an acre of celery varies with the condition of both soil and plants, planting distances, and efficiency of labor, but will not be less than $\$$ I 5 or more than $\$ 25$.

Distances to Plant.-The planting distances must necessarily be governed by the method of blanching to be employed, and by the fertility of the soil. The principal methods of setting are single row, double row, and solid beds. The single and double row plantings can be blanched either with boards or by banking with earth, the alleys being made wider for blanching with earth. By the solid bed method the blanching is performed by shoveling earth between the plants, or if a heavy growth be 


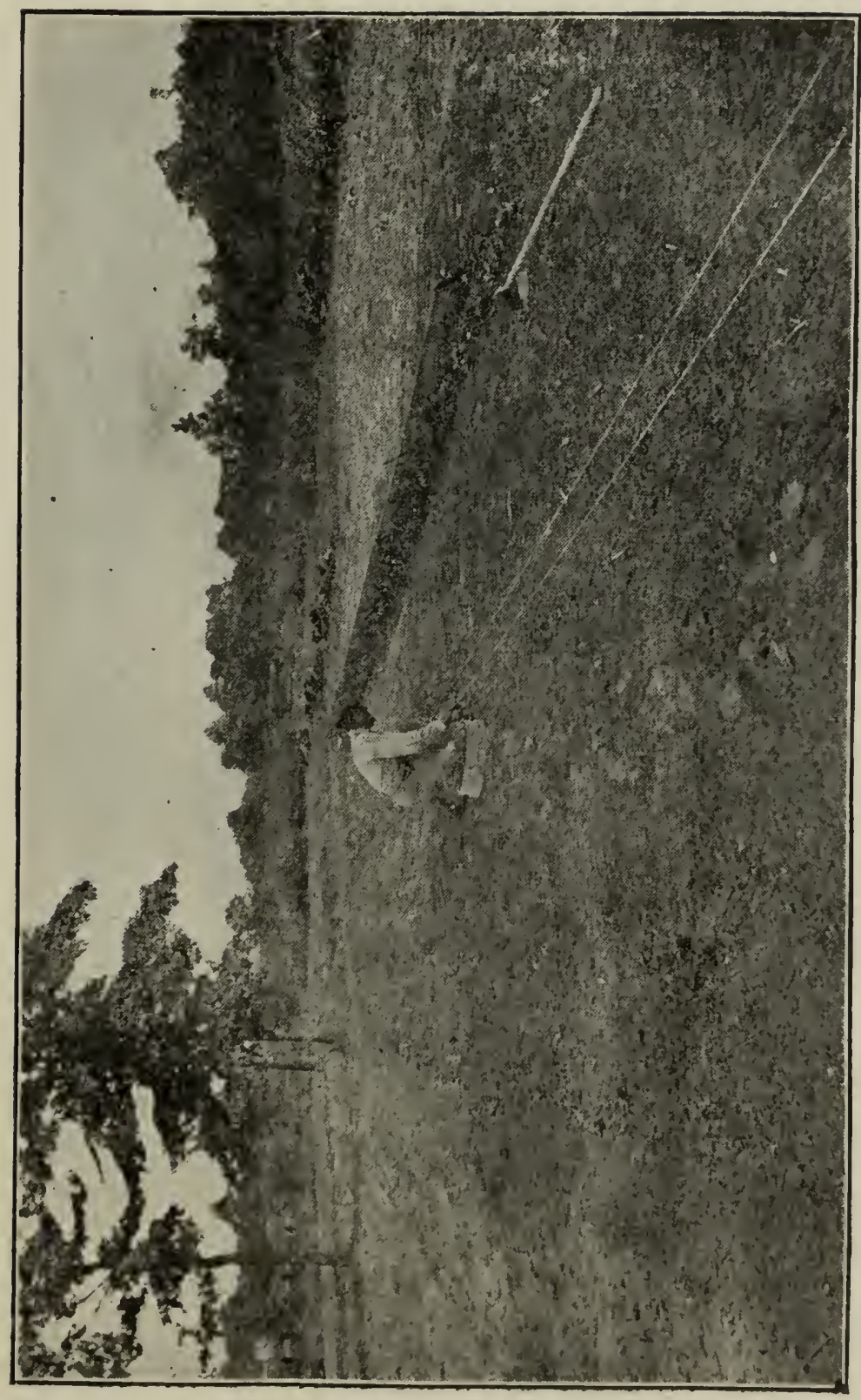

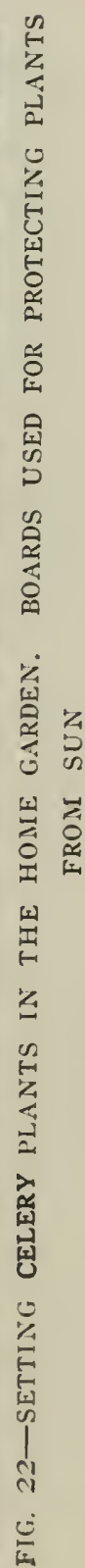


secured the plants will form sufficient foliage to exclude the light and blanch themselves.

Planting in single rows 3 feet apart, with the plants 4 inches apart in the rows, for blanching with boards will undoubtedly give the best possible yield, but requires 29,000 square feet of boards to blanch an acre at one time. Twelve-inch boards will blanch a double row, with the plants 6 inches apart each way, and by planting the double rows 4 feet apart on centers, 2I,000 square feet of lumber is sufficient to blanch an acre at one time, and the

TABLE II. PLANTING DISTANCES

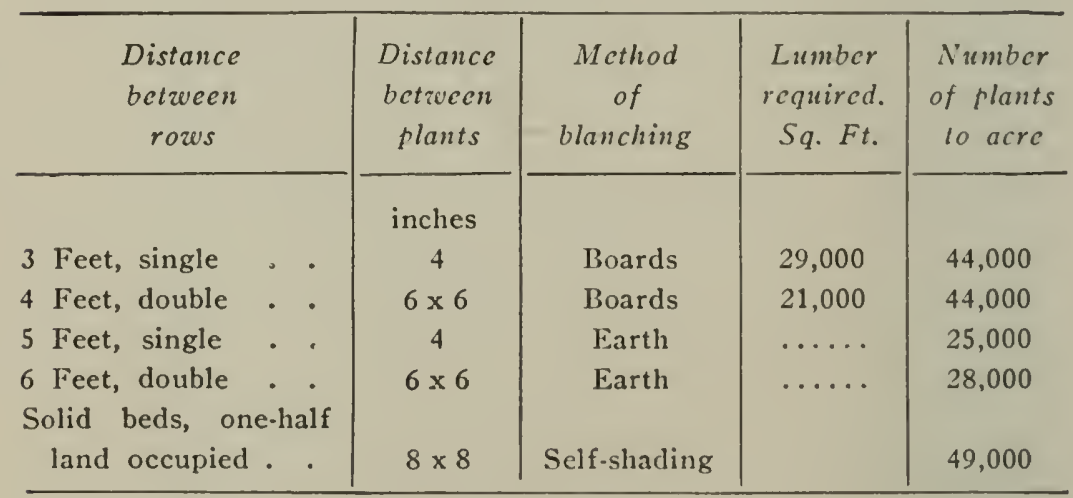

number of plants is the same in either case. Blanching with earth requires that the spaces or alleys between the rows shall be at least 4 or 5 feet, and where the plants are set in double rows this space should be at least 6 feet on centers.

Where the land for growing celery is extremely fertile and the area limited in size, the plan of planting in solid beds may be resorted to, but is not 
recommended on a large scale. By planting 8 inches apart each way, and devoting one-half the available space to beds, an acre would require 49,000 plants for setting. See Table II, planting distances. This method of growing celery is frequently alluded to as "The New Celery Culture," but plants grown in this way require more hand labor for their cultivation, are more subject to disease, and as a rule will not produce as much marketable celery to the acre as by any one of the other planting methods.

Overcoming Unfavorable Conditions at Planting Time.-Where celery is grown under conditions that are not entirely suited to its requirements, it may be necessary to provide special facilities for the care and protection of the plants until they become established in the open ground. When planting in soil that is deficient in moisture, or where it is impossible to get the soil into proper mechanical condition, the plants will be greatly benefited by dipping their roots in a thin slime of clay and water as they are removed from the plant bed. This process is commonly termed "puddling" and covers each rootlet with a coating of moist clay which protects it from the air and insures a perfect contact with the soil when the plant is set. When setting celery plants in dry earth, the soil should not be entirely filled in around them until a small amount of water has been applied, then the dry soil should be drawn over that which has been moistened in order to prevent baking.

Mulching.-If a heavy clay soil, or a very light sandy soil, only, is available for the growing of the 
home supply of celery, it will be desirable to apply a mulch of some kind along the rows. As soon as the plants are in position, and before any water is applied, cover the ground for a distance of 8 or 10 inches on either side with any finely-divided material that will shade the top of the soil, hold the moisture, and prevent a crust being formed after watering. Half-rotted manure is preferable for this purpose, as in addition to acting as a mulch it has considerable fertilizing value. Among materials that may be used as a mulch are pine needles, leaves, cornstalks run through the cutter, and clippings from the lawn, none of which, however, are as good as manure. Have the material to be used as a mulch near at hand, and as the plants are set cover the soil around them to a depth of 2 inches, bringing the mulch close to the base of the plant, but being careful to allow none to get into the heart. 


\section{CHAPTER VII}

\section{Cultivation}

Frequency of Cultivation.-Frequent, shallow cultivation should be practiced from the time the plants are set in field or garden until the blanching process is well under way. At first the cultivation may be quite near the plants, but after active growth begins the roots of celery are to be found close to the surface and the cultivation should not be so deep or near the plants. The rule should be to stir the surface once each week in dry weather, and as soon after showers or watering as the soil is dry enough to work, in order that the air may enter the soil freely.

In a short time after the celery is planted in the field it will be necessary to give at least one careful hand working to remove the weeds and loosen the soil around the plants. After the plants become large enough to shade the soil there will be no further difficulty with weeds near the row, and frequent cultivation will keep the middles clean. The effects of drouth may in most cases be met by frequent shallow cultivation, supplemented by the use of water if available.

Tools Adapted to Celery Cultivation.-For the growing of the home supply of celery special tools will not be required and the work can be performed by means of implements ordinarily used for culti- 
vating the garden. Where any considerable quatttity of celery is grown it will be economy to provide

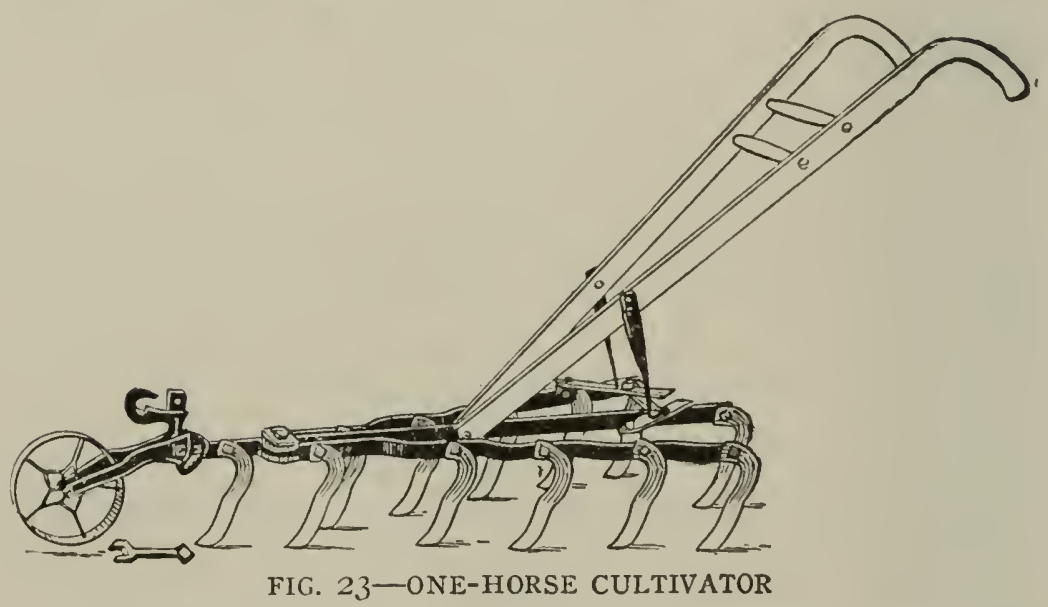

a few special tools fur its cultivation. The harrowtoothed cultivator, having 12 to 16 slender teeth, is one of the best tools for celery cultivation. A rake-
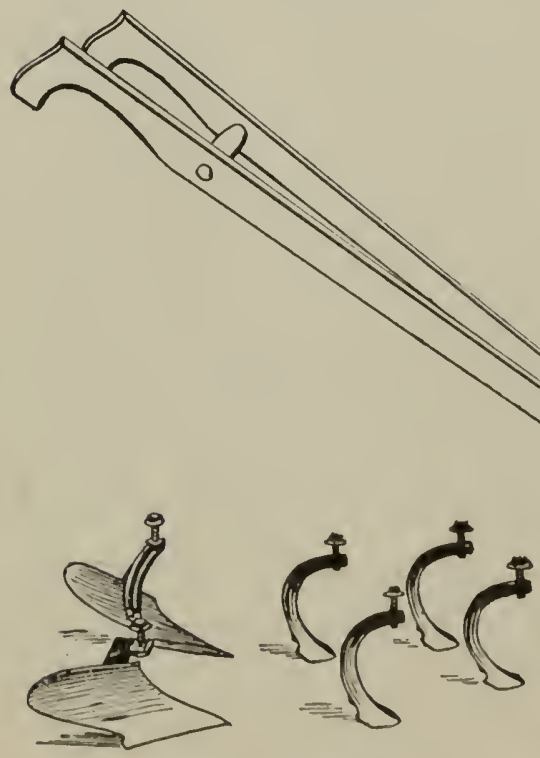

FIG. 24-WHEEL HOE FOR CELERY CULTIVATION 
like leveling attachment to the cultivator is useful, as it may be run quite close to the row without going deeply into the soil. The greater part of the hand work can be accomplished by means of some form of wheel hoe which may be run very near the small plants without injuring them. This implement is also desirable for cultivating a small area of celery in the home garden.

There are also a number of small hand tools that are desirable for working among the plants, espe-
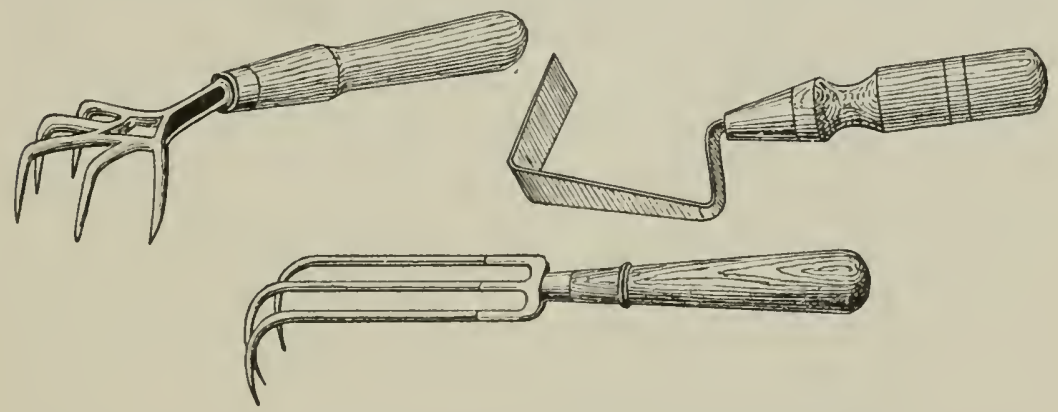

FIG. 25-HAND-WEEDING TOOLS FOR WORKING AROUND CELERY PLANTS

cially in the culture of celery on a small scale. (Fig. 25.) A very serviceable tool may be constructed by driving three or four wire nails through the end of a lath and using as a rake for loosening the soil between the plants; this tool is especially adapted for working the soil in the plant beds.

Toward the latter part of the growing season the roots of the celery will extend entirely across the rows and the cultivator should be replaced by some form of sweep that will merely drag over the surface. A tool for this purpose can be improvised by 
removing the teeth from a one-horse cultivator and bolting two pieces of $2 \times 4$-inch scantling on the under side of the frame in the form of a letter $\mathrm{V}$ with the open part towarl the front; the narrow portion should not quite join, but there should be a space of about 6 inches at the back through which the soil may pass freely. If the weather is extremely dry this sweep should be run between the rows at least twice a week to keep the surface loose and maintain a dust mulch. 


\section{CHAPTER VIII}

\section{Irrigation}

IN its natural habitat the celery plant is found in low, moist places, where there is an abundance of moisture at the roots and freedom from flooding. Celery will not thrive in sour, stagnant soil but requires that the water with which it is supplied be pure and that there should be free movement of the moisture in the soil. An excess of moisture in any soil will exclude the air, and without air in the soil the plants will not thrive. Excessive watering is detrimental and the chances of producing a good crop are on the side of thorough cultivation in connection with the natural rainfall, rather than constant watering and neglect of cultivation. This fact is demonstrated by the results of a rainy season when proper cultivation is impossible and an inferior crop is the result. Too many of our celery growers attempt to force the growth of their plants by frequent watering, and at the same time neglecting cultivation. When necessary to irrigate, give the land a thorough soaking and as soon afterward as possible stir the surface soil to form a mulch and continue to cultivate frequently until desirable to apply more water.

Sources of Water for Irrigation.-The principal sources of water for irrigation purposes in the celery growing districts are lakes, rivers, small streams, 
shallow and flowing wells. In localities where flowing wells are possible, this is the cheapest source of water for watering celery. We occasionally find a location where the water can be brought from some higher elevation and delivered in the celery fields by gravitation, but, as a rule, some form of pumping machinery to lift and deliver the water will be required. Where the lift is not great-that is, not over 20 feet in all-the pumping can very easily be done by means of some form of rotary or centrifugal pump which may be driven either by a steam or gasoline engine.

Quantity of Water Required.-The quantity of water required for the production of a crop of celery is in most cases not great, and rarely exceeds 5 inches over the entire surface during the period of growth in the field. The application of five waterings of $I$ inch each to an acre will require the handling of 136,000 gallons of water, or a little over 27,000 gallons at a watering. This is not a large amount of water for handling by a large pump and the cost of applying will vary under different conditions. As a rule the actual cost of watering an acre of celery, if the work is done on a comparatively large scale, should not exceed $\$ \mathrm{I}$ an acre for each watering, or $\$ 5$ for the entire season. Celery requires the most water at the time when it is making its greatest growth, which occurs late in the summer. As the crop approaches maturity, the water should be applied sparingly, as the soil evaporation is not so great at that time of the year, and when the soil becomes too moist it is difficult 
to get it dry enough to work. Excessive moisture in the soil at the end of the season will invariably produce celery of inferior flavor and poor shipping qualities.

Irrigation on Muck Soils.-On low lying peat or muck soils, it may not be necessary to apply any water in addition to the natural rainfall, but irrigation is almost indispensable on clay or sandy upland soils. Muck or peat soils are generally located in a basin or depression of the surrounding soil formation, and by pumping on water continuously the muck will absorb it until saturated and the water will rise almost to the surface. This should be avoided as the soil will become water-logged and the celery plants will be permanently injured. If it is found that sufficient moisture cannot be maintained in the surface soil by frequent shallow cultivation, it may then be necessary to resort to irrigation, but some form of surface irrigation is preferable to flooding the muck basin and raising the water table in the soil. The underlying muck, which has not been exposed to the action of the air for centuries, is filled with the acids of decaying vegetable matter, and these acids are injurious to the roots of plants with which they come in contact.

Methods of Irrigating.-There are three principal systems of irrigation used by the celery growers of this country: (I) surface ditches, (2) overhead sprinklers, and (3) subirrigation. Each of these systems has its adlaptations and limitations which determine the possibility of its employment under given conditions. 
Wooden Flumes and Open Ditches.-Where the open ditch system of distributing the water is employed, the water can be conveyed from the pump to the ditches by means of a long wooden trough constructed by nailing three planks together and leaving the top open. Where a large field is to be watered, the trough or flume may be run entirely along one side and' secondary flumes taken off at intervals to distribute the water to the ditches. The secondary or distributing flumes should cross the ditches and be raised about I foot from the ground, openings being provided in the bottom of the flume for the discharge of the water into the ditches. The openings or traps in the bottom of the flume should be cut with sloping edges and a piece of plank having the same shape fitted to them in order to stop the flow of water into any particular ditch. Where the distributing flumes join the main flume they should be provided with gates to control the water, or the end of the distributing flume may be placed beneath the main flume and the water discharged through a trap in the bottom of the main flume. The flumes will necessarily be supported upon trestles or posts set in the ground and the end next the pump must be raised several feet, unless the ground slopes naturally, in order that the water may flow freely through the flumes and in to the ditches.

Iron pipes may be employed instead of the wood flumes, numerous tees being inserted in the lines of pipe for the discharge of the water. These openings should be plugged and the plugs removed 
when it is desired to attach a piece of hose at the opening for filling the ditches within reach; the hose may then be detached, the plug replaced, and the hose moved to the next opening. With a hose 50 feet long it will only be necessary to have the openings every roo feet along the line of pipe. Valves will be found more desirable than plugs for closing the openings, but their use adds considerably to the expense of installation. A threaded nipple should be inserted in one end of the hose for attaching it to the pipe, and one and one-fourthinch hose will be found to be the most convenient size for general use.

The iron pipes are more desirable than the wooden flumes, as they can be laid upon the ground or on blocks and do not require leveling or grading, the only requisite being that the source of supply of the water be somewhat higher than the delivery openings, or that the water be driven through the pipes under pressure. In the autumn, after the irrigation work is finished, the pipes should be carefully drained to prevent freezing, or be disconnected and placed under shelter until the following season. Galvanized pipes are preferable, or if black pipe be employed it should be painted on the ontside with mineral paint or asphaltum varnish from time to time to prevent rusting.

Overhead Sprinkler Systems.-One of the most satisfactory methods of applying water to the surface of the soil is the deluge sprinkler system. By this method, lines of iron pipes are laid on the surface of the soil 16 or 18 feet apart, with upright 
pipes about 3 feet high every 16 or 18 fect along their length. At the top of each upright is placed a distributer, known as a deluge sprinkler, which will spread the water very evenly over the entire surface between the uprights. This system has its disadvantages; it is costly to install, the lines of pipe and uprights are in the way of cultivation, and the

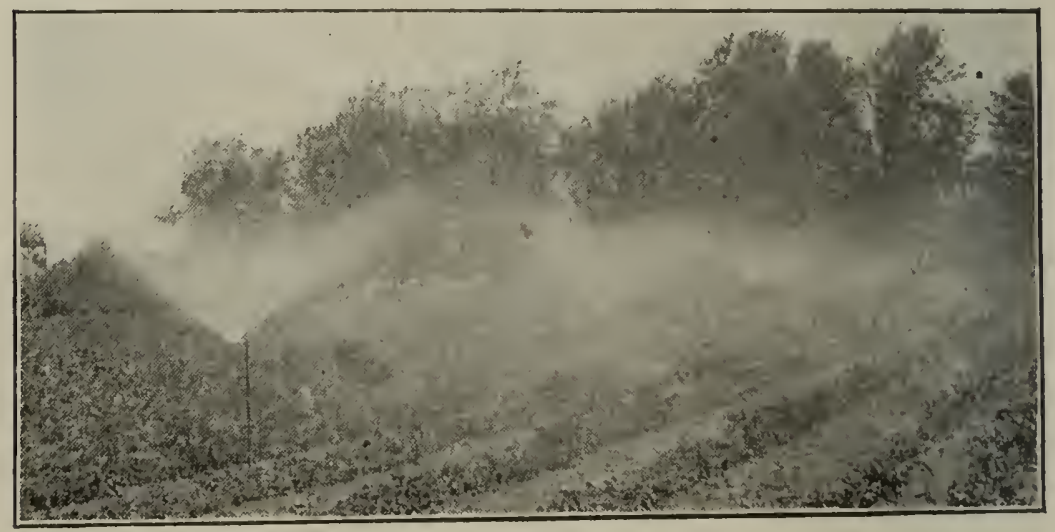

FIG. 26-DELUGE SPRINKLER SYSTEM OF IRRIGATING

pipes must be taken up at the end of each season and relaid at the beginning of the next.

The expense of pumping is greater than for the open ditch system, as the water must be driven through the pipes under a pressure of at least 50 pounds to the square inch in order that the sprinklers will distribute it uniformly. An eight to tenhorse power pump, with a three-inch suction and two and one-half-inch discharge pipe, will be required to operate 15 of these sprinklers at one time, but these will thoroughly soak an area of about 20 square rods every 15 minutes, or I acre every two 


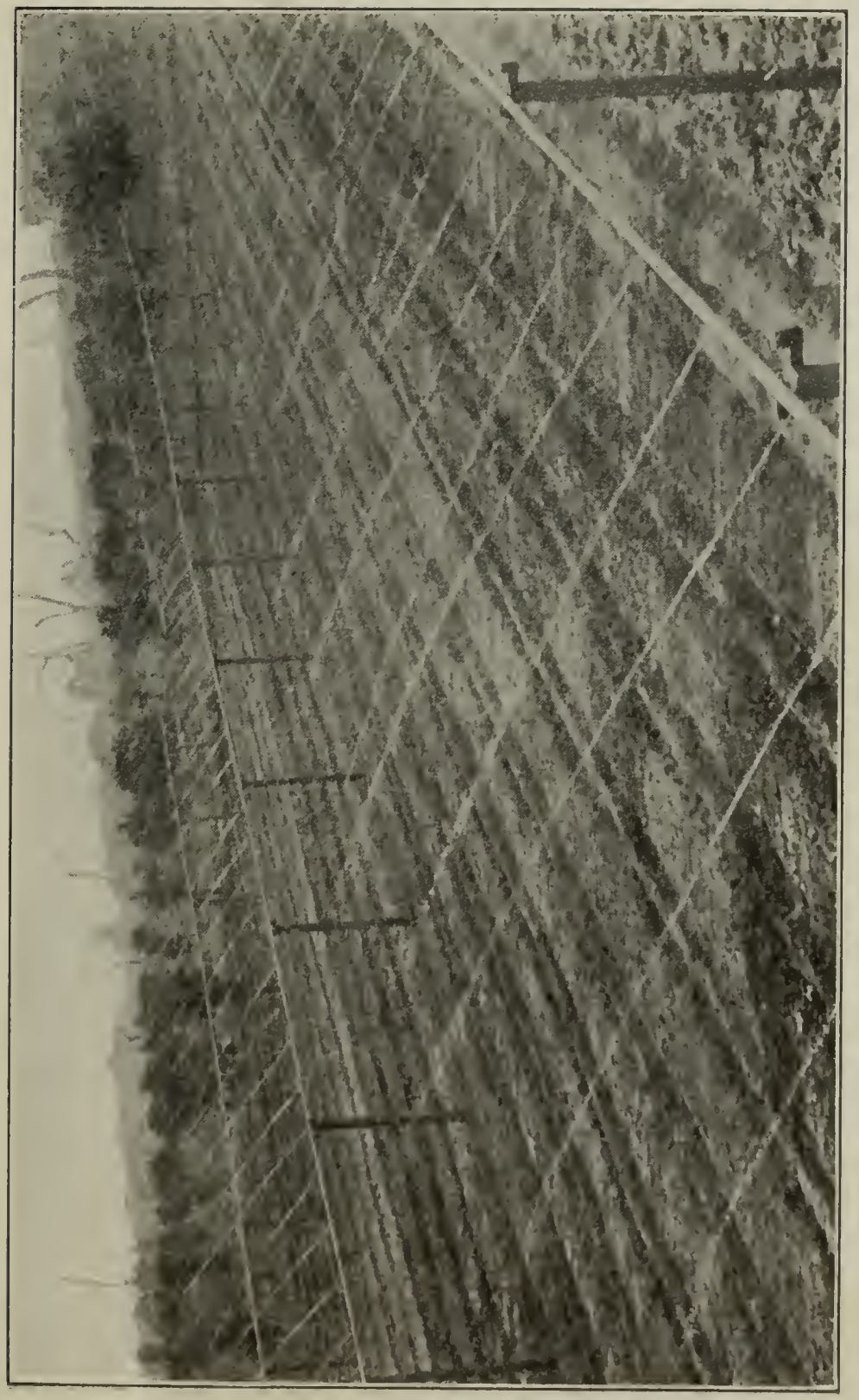

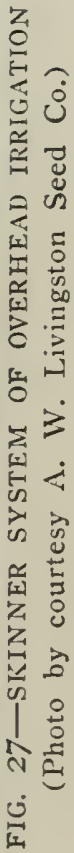


hours. With the cost of fuel and oils for a ten-hour day at $\$ 5$, and the wages of two men at $\$ 3$, the cost for running expenses of watering five acres would be at the rate of $\$$ I.6o an acre for each watering, or $\$ 8$ an acre for the entire season. To equip one acre with the deluge sprinkler system will require the following materials :

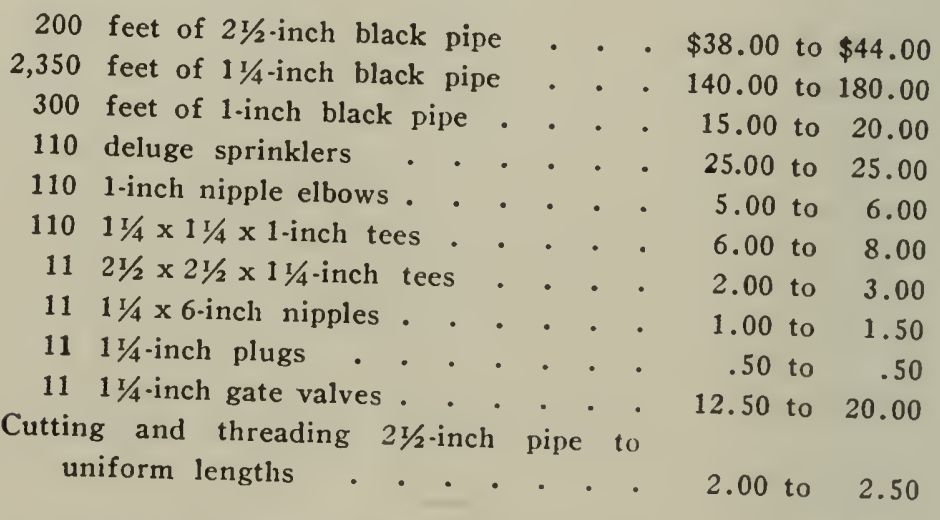

Total exclusive of main leading to field and

labor of laying pipes . . . . $\$ 247.00$ to $\$ 310.50$

This estimate does not include any share of cost for pumping outfit, main pipe leading to field, or source of water supply, as it is assumed these will be a necessary part of any watering system. In using the sprinkler system it is preferable to apply the water at a time when the sunshine is not at its height in order to avoid scalding. (See Fig. 26 for illustration of deluge sprinkler in operation.)

Another method of irrigating celery or similar crops by overhead sprinkling is that known as the Skinner system, consisting of a long line of pipe supported 4 to io feet from the ground upon posts 
and so mounted that it will turn freely upon its bearings. At intervals of every 4 , feet along one side of the pipe holes are drilled and small brass nozzles inserted. At one end the pipe is connected to the water main by means of a flexible ground joint which will permit of its being revolved. The nozzles are turned to one side and the water applied, and as the plants become sufficiently watered the pipe is gradually turned until the other side is

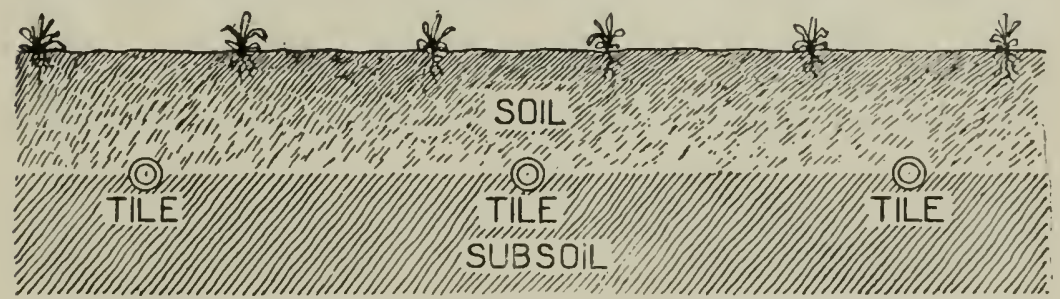

FIG. 28-CROSS-SECTION SHOWING ARRANGEMENT OF TILES FOR SUBIRRIGATION

(Redrawn from Farmers' Bul. No. 255, U. S. Dept. of $\Lambda \mathrm{gr}$.)

reached. In this way a strip of ground from 50 to I 50 feet in width may be watered, but the width of the strip will depend largely upon the direction and velocity of the wind, and the lines of pipe should be placed at intervals of not more than 50 feet.

Subirrigation as Applied to Celery Growing.-By the subirrigation method the water is applied to the roots of the plants through drain tiles or perforated pipes laid on a level a few inches below the surface of the soil. This system is especially adapted to use in back-yard gardens where water under pressure is available, and where the area under cultivation is small. Subirrigation will prove most satisfactory where the surface soil is underlaid with clay 
or some hardpan that will prevent the escape of the water. Openings to the tiles should be provided at least every too feet for the admission of the water, and the watering may be accomplished by inserting the end of a hose and allowing the water to run into the tile for a short time. By this method the water finds its way into the soil through the joints of the tiles, while the surface soil may be kept quite dry and under frequent cultivation. A cross-section of soil showing the proper arrangement of tiles is shown in Fig. 28.

The subirrigation system of watering is being applied on rather a large scale by the celery growers around Sanford, Florida. Here the celery fields are

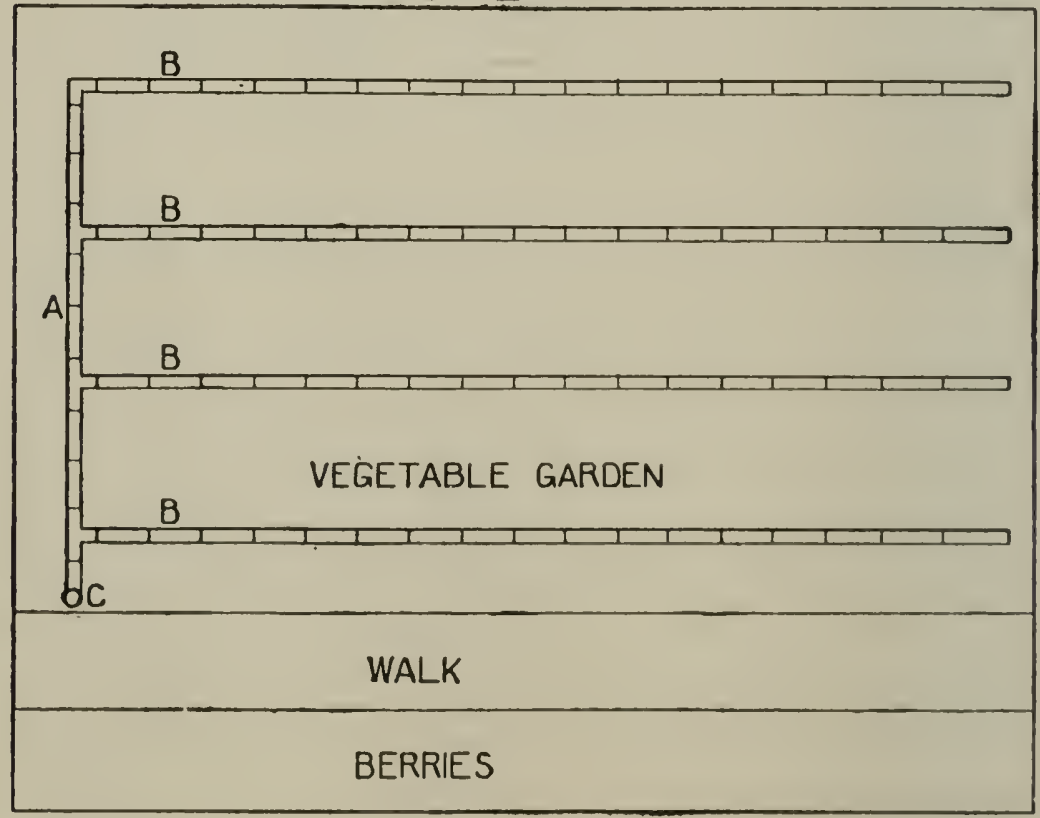

FIG. 29-PLAN OF SUBIRRIGATION SYSTEM ADAPTED TO BACK-YARD GARDEN 
located along the sloping border of a lake; the water is procured from flowing wells located at the upper side of the slope. Leading from the higher ground toward the lake are wooden flumes set into the ground to a depth of about 12 inches. Nearly every 20 feet along the flume there are openings into lines of three-inch drain tiles laid practically on a level

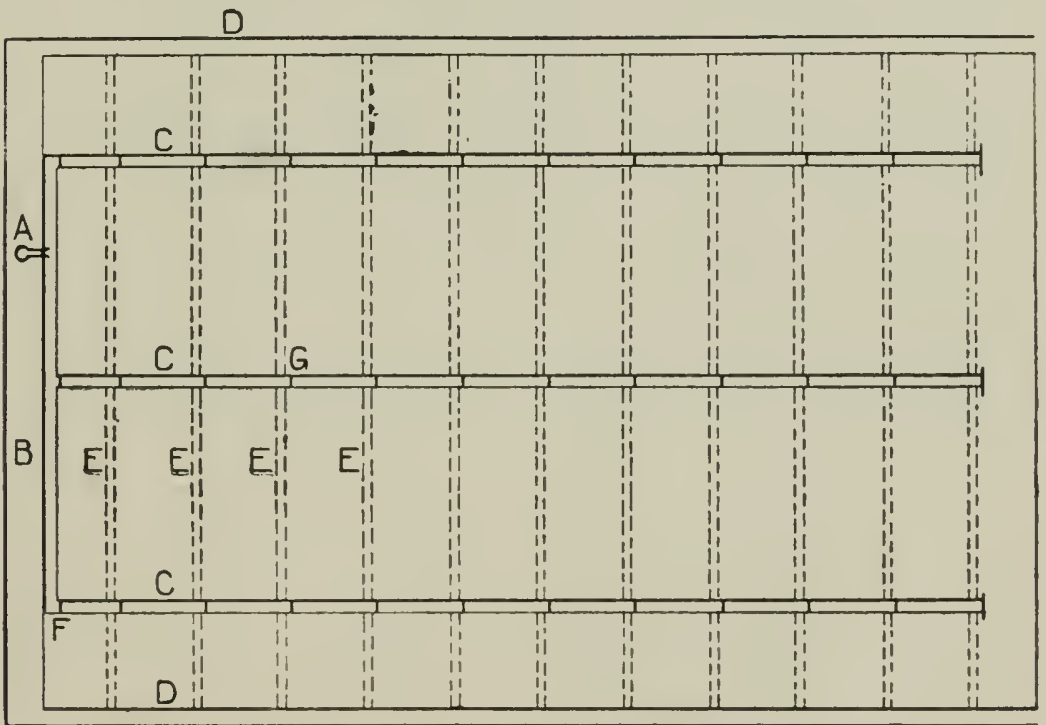

FIG. 30-PLAN OF SUBIRRIGATION SYSTEM AS EMPLOYED IN FLORIDA $A$, well; $B$, head flume; $C$, distributing flumes; D, open ditch; E, subirrigation tiles; F, sluice gates; $\mathrm{G}$, check gates

across the slope and at right angles to the flume. The opening into the tile is controlled by means of a slide which is raised for the admission of water. A few inches below the opening into the tile is located a check board which does not extend to the top of the flume, but serves to back the water into the tile and permit the surplus to flow over and 
pass on to the next tile. The water entering the tiles finds its way to the soil through the openings between them and gradually works down the slope toward the next line of tiles. During rainy seasons the wells are closed down, the check gates and overflows all removed, and the irrigation system is made to serve as a means of draining the land. A plan of this system is shown in Fig. 30.

Temperature of Water for Celery Irrigation.As celery thrives best under cool conditions it is desirable to use water at a rather low temperature for irrigation. Warm, stagnant water, that has lain for days exposed to the heat of the sun, should not be used for irrigating celery. Water that is pumped direct from wells and which has a natural temperature of from 50 to 60 degrees is preferable. 


\section{CHAPTER IX}

\section{Diseases of Celery}

IN the production of a small quantity of celery for home use, plant diseases are not liable to cause serious difficulty, but on a large scale where many thousands of plants are grown together the chance of infection is greater. In the commercial production of celery it is necessary to observe every possible precaution to avoid loss from disease. Climatic conditions play an important part in the control of celery diseases. Owing to prevailing atmospheric conditions, which favor the spread and development of diseases, certain localities are not suited to the production of celery, although the soil and marketing facilities may be ideal. In regions where celery can ordinarily be grown without loss from diseases there will occasionally be a season during which a large portion of the crop will be affected. A warm, humid atmosphere with sultry nights is liable to develop diseases, but cool nights with clear atmosphere and bright sunshine during the day furnishes ideal conditions for holding diseases in check. The self-blanching varieties are more subject to the attacks of diseases than the stronger-growing green kinds.

Damping.-Immediately after the seedlings appear they are subject to attack from the disease known as "damping," which causes the stem and 
root to decay near the surface of the soil. Damping may be attributed to any of the following fungi: Sclerotinia libertiana, Rhizoctonia, and Fusarium. The greatest liability of injury from this source is during the first two weeks after the seedlings appear. Plenty of light, care in watering, and thorough ventilation are the only satisfactory methods of preventing loss from damping. If the plant bed is in the open ground it may be necessary to shelter it from continuous rains, and a light dusting with dry Bordeaux mixture may prove beneficial. As a pretaution against damping, seedlings that are in trays may be subwatered by setting each tray for a few minutes in a shallow trough, allowing the water to enter the bottom of the tray through the drainage holes and moistening the soil without wetting the surface.

Blight ${ }^{1}$.-The disease of celery known as "blight" is caused by Cercospora apii, which attacks the leaves of the plants, appearing as grayish spots which turn brown or to a burned appearance within a few days. The commercial celery crop is greatly injured by the blight and the disease is liable to appear at any time after the plants are set in the open field. The blight generally appears first upon the outside leaves and rapidly spreads until the whole plant is infected. Warm days and nights with a high degree of moisture in the atmosphere are conditions suitable to the development of blight. Cool nights and a dry atmosphere will generally

IU. S. Dept. of Agr., Farmers' Bul. No. 148. 
check the attack, and the plants will sometimes outgrow the disease, but the product will not be firstclass. When the blight has become well established it is then too late for effective remedial measures,

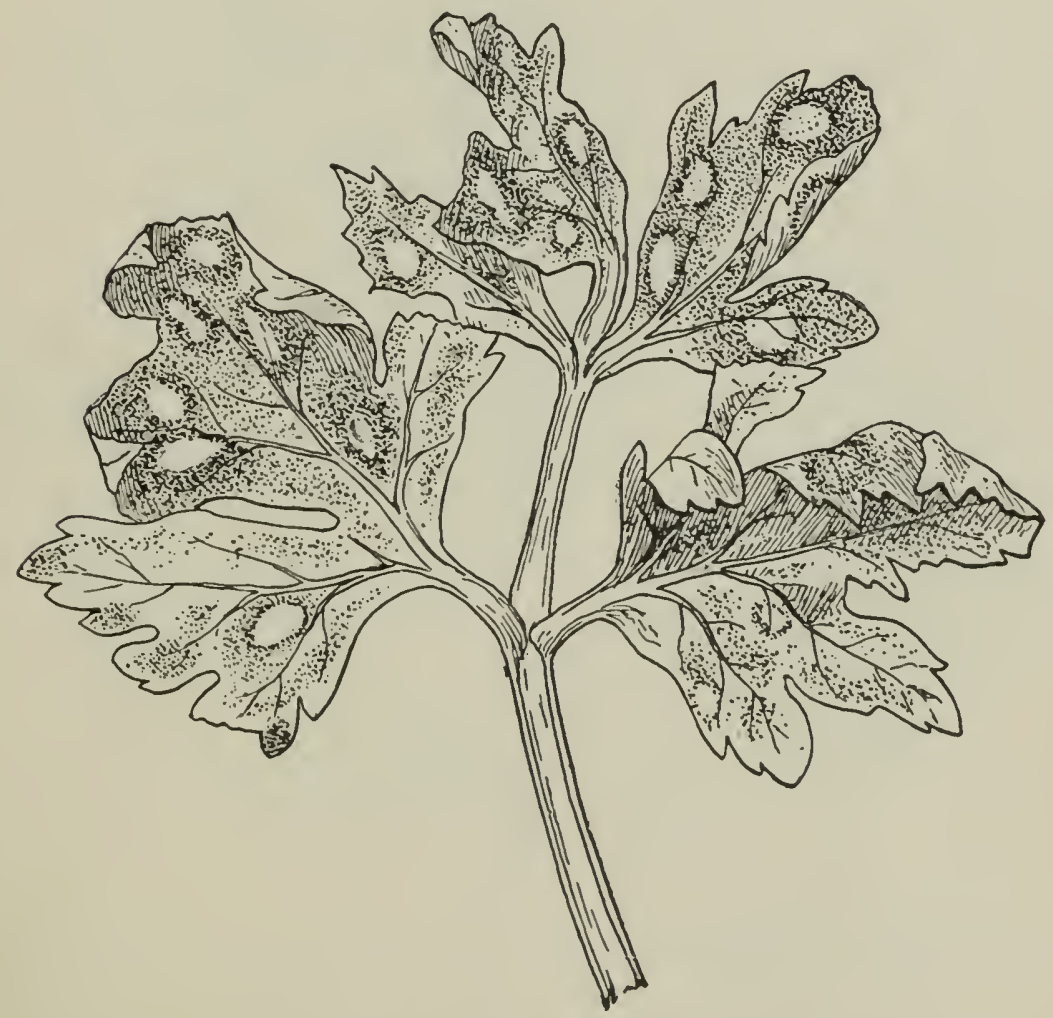

FIG. 3I-LEAF AFFECTED WITH CELERY BLIGHT (Cercospora apii) (Redrawn from Halsted, N. J. Expr. Sta. Special Bui. 1902)

and while its progress may be checked it is doubtful if it can be eradicated. If the plants are kept growing vigorously from the very start, and proper cultivation maintained throughout the growing season, there will be little danger from blight. 
80

Another form of leaf blight, and which is commonly confused with the ordinary blight, is caused by the fungus known as Septoria petroselini ${ }^{1}$ var.

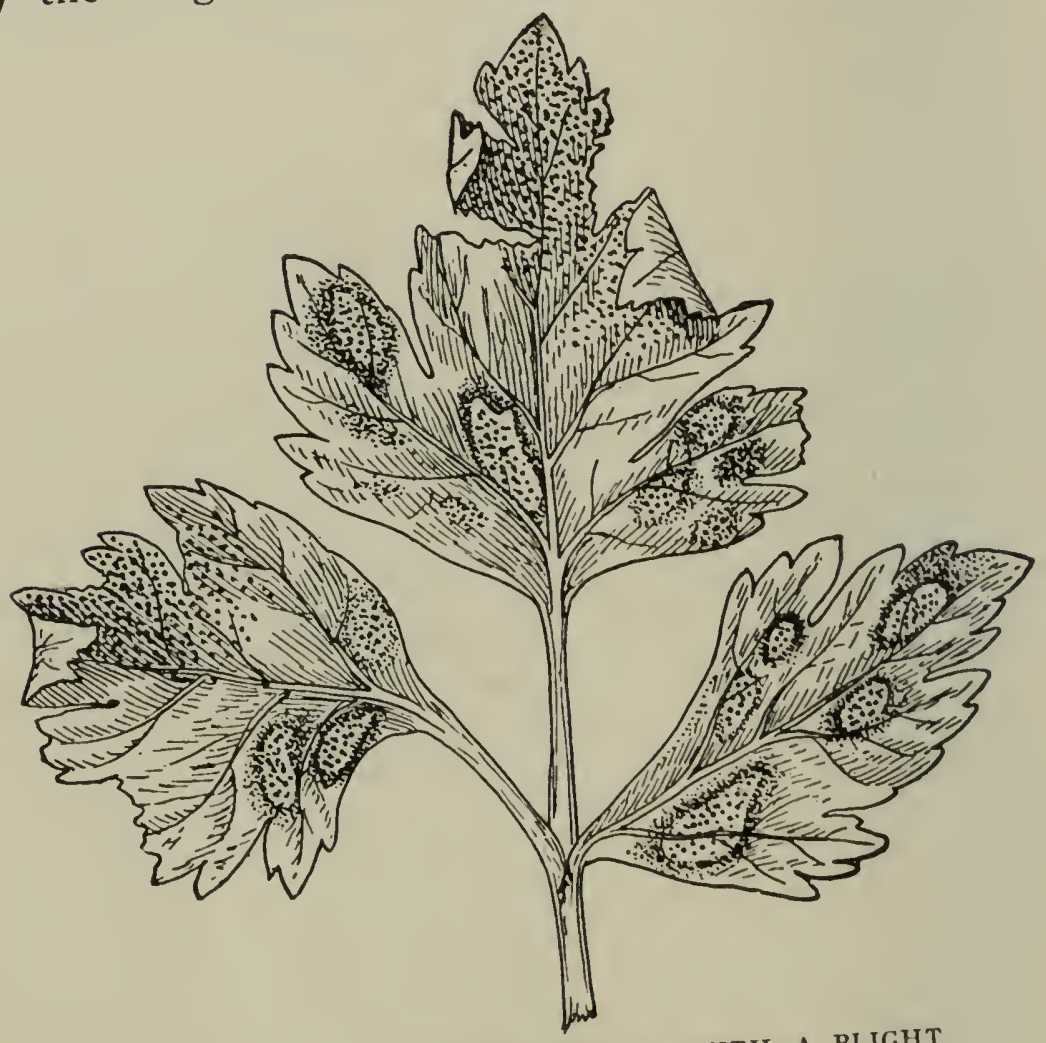

FIG. 32-CELERY LEAF AFFECTED WITH A BLIGHT

(Septoria petrosclini var. apii)

(Redrawn from Ilalsted)

apii. In general appearance this disease is very similar to the ordinary blight, and the treatment is the same in either case.

Leaf Spot.-This disease, while similar to the blight in its action, is somewhat different in general 1 N. Y. Expr. Sta. Bul. No. 51. 
appearance. Leaf spot is caused by the fungus which bears the name Phyllosticta apii ${ }^{1}$ and differs from the blight in that it makes its appearance in

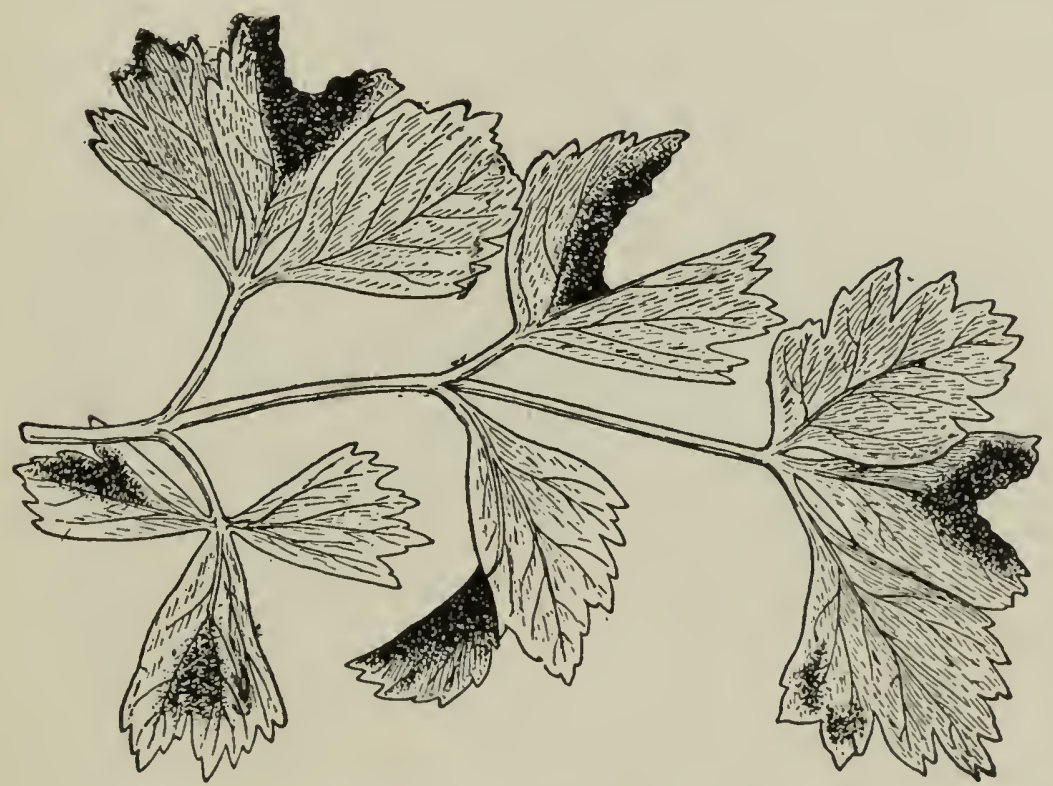

FIG. 33-CELERY LEAF AFFECTED WITH LEAF-SPOT

(Phyllosticta apii)

(Redrawn from Halsted)

the form of dark brown spots and gradually spreads until the whole leaf is covered.

Celery Rust ${ }^{1}$.- The true rust of celery is caused by the fungus known as Puccinia bullata, and appears in the form of numerous small, reddish-brown spots on the leaves. Celery rust has not yet made its appearance in this country, but it is only a matter of time until it will become widely distributed.

Blanch-rot or Heart-rot.-Professor Halsted of

1 New Jersey Expr. Sta. Special Bul. 
the New Jersey station describes a bacterial disease which attacks the hearts of celery, causing them to decay very quickly, especially in the presence of warmth and considerable moisture. This is evidently the disease which frequently causes the loss of celery in stcrage. When attacked by this disease,
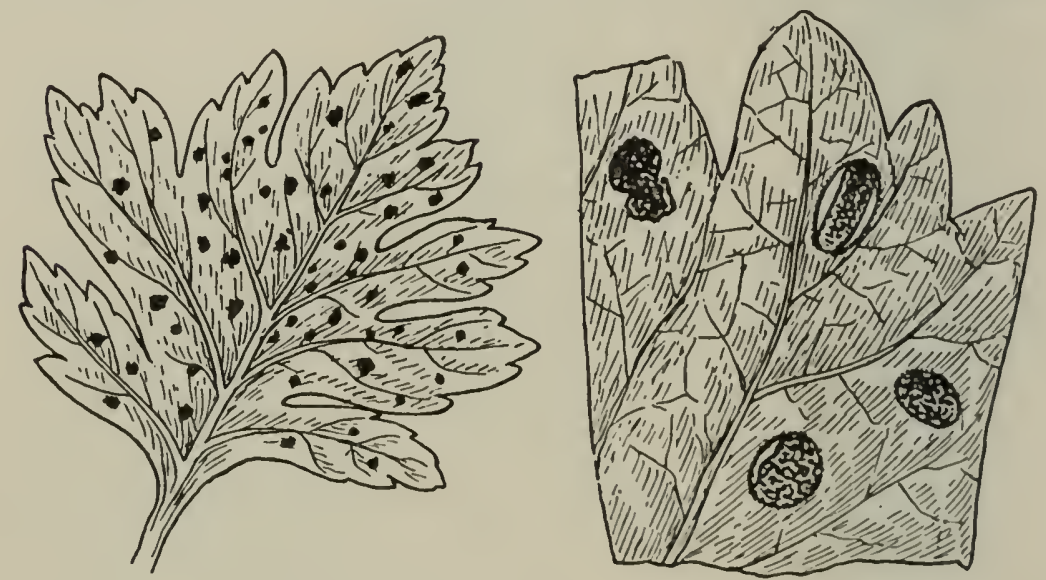

Fig. 34-Celery LeAF AFFECted ivith RUSt (Puccinia bullata) ENLARGED PORTION AT RIGHT

(Redrawn from Halsted)

the stalks, and especially those in the heart of the plant, turn a dark brown or black color, soften and decay very quickly. This disease is often observed where celery is blanched by means of boards during extremely warm weather. The blanch-rot or heartrot can be controlled in the storage house by ventilation, cooling, and care that the tops of the celery do not become wet.

Root-knot.-This disease appears in the form of numerous nodules upon the roots of celery, and is caused by the fungus Heterodera radicicola. Root- 
knot seems to appear on plants growing on soils which have been heavily manured shortly before planting to celery. Very little is known about this disease, but, as a remedy, it may be desirable to devote the land to some other crop for two or three years.

Prevention and Control of Celery Diseases.While there are no specific remedies for the diseases of celery when they become established, considerable may be accomplished by way of preventing and controlling them. If celery is being grown on a large scale it will be advisable to begin the preventive measures while the plants are in the plant bed, and continue the treatment until the blanching process begins. Thorough spraying every ten days or two weeks with mixtures containing copper, especially ammoniacal carbonate of copper and Bordeaux mixture, will generally be sufficient to prevent the diseases getting started. As a result of experiments conducted at the Maryland agricultural experiment station by Dr. C. O. Townsend ${ }^{1}$ it was demonstrated that shading was of some assistance in combating the blight of celery, but that complete immunity was obtained by spraying frequently with the ammoniacal carbonate of copper sulution. This solution is prepared by dissolving I ounce of copper carbonate in just enough ammonia water to completely dissolve the copper and then dilute to 9 gallons with cold water. The strength of commercial ammonia water varies so greatly that no definite amount can be given, but it is generally

1 Mạryland Expr. Sta. Bul. No. 74. 
about one pint for an ounce of copper carbonate. Care should be exercised that all of the ammonia is acted upon by the copper or burning of the leaves may result. Before adding the copper carbonate the ammonia water should be diluted with 2 or 3 pints of cold water. A stock solution may be prepared and an amount containing I ounce of copper carbonate diluted to 9 gallons for use.

Bordeaux mixture for use on celery is prepared by slaking 6 pounds of fresh quicklime in sufficient water to prevent its burning, then adding water to make 25 gallons of the milk of lime. At the same time dissolve 6 pounds of copper sulphate, also known as bluestone, and blue vitriol, by placing it in a porous burlap bag and suspending it in 25 gallons of water. When required for use, these solutions are well stirred and poured simultaneously into a cask or barrel of sufficient size to hold the entire amount. (See Fig. 35.) The solutions should be passed through a strainer as they are being mixed in order to remove any particles that would interfere with the working of the pump or spray nozzles. Stock solutions of the lime and copper may be prepared ready for dilution and use at any time by dissolving the lime and copper in separate tanks at the rate of $\mathrm{I}$ pound to a gallon of water. In making the mixture from the stock solutions stir well and then take 6 gallons of each and add $3^{8}$ gallons of water, making 50 gallons in all. Bordeaux mixture should be used as soon as made, and while the copper solution will keep indefinitely the lime will give better results if freshly slaked, Bordeaux mixture will 
stain and discolor the plants and for this reason the ammoniacal solution of copper is more desirable for use on celery.

Spraying of this nature is frequently performed by means of a knapsack sprayer, but on a large scale

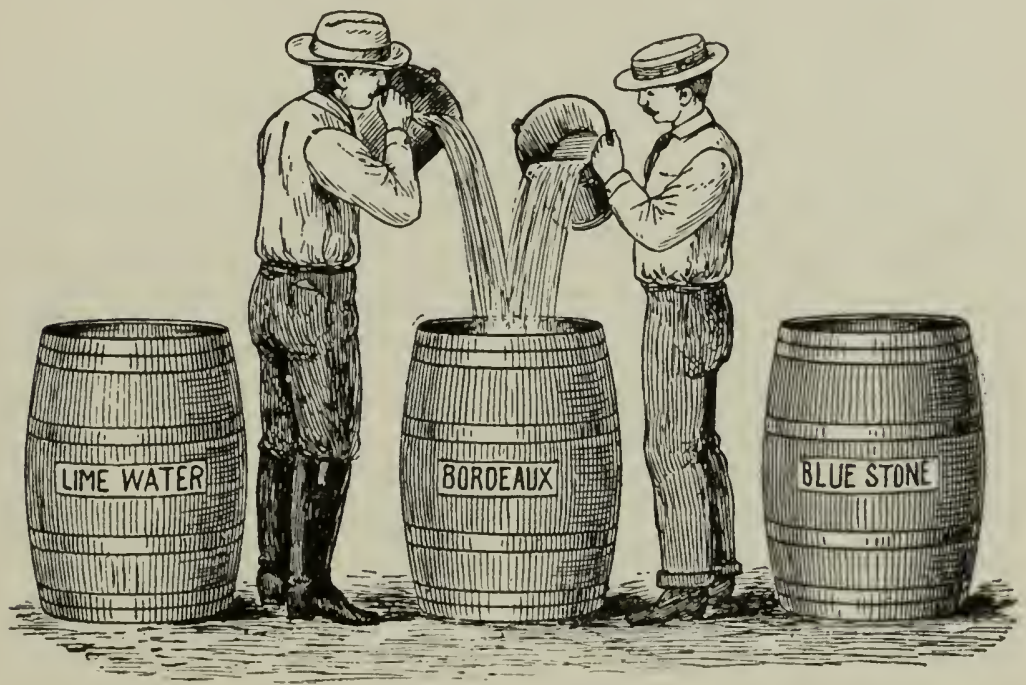

FIG. 35-THE PROPER WAY TO MAKE BORDEAUX (From W. G. Johnson)

some form of spraying machine will be desirable. There are several horse-drawn spraying machines upon the market, a number of which are fitted for spraying three to five rows at one time. (See Fig. 36.) In spraying celery it should be the aim to reach every part of the plant with a fine spray, and unless the work is done very thoroughly it will fail of accomplishing the desired result. The plants should be sprayed at least once before leaving the plant bed, and from four to six times while in the field. 
Many of the large growers of celery have discontinued spraying owing to the cost of materials, equipment, and labor, preferring an occasional loss of a large part of the crop from blight. A high state of fertility and thorough cultivation are of impor-

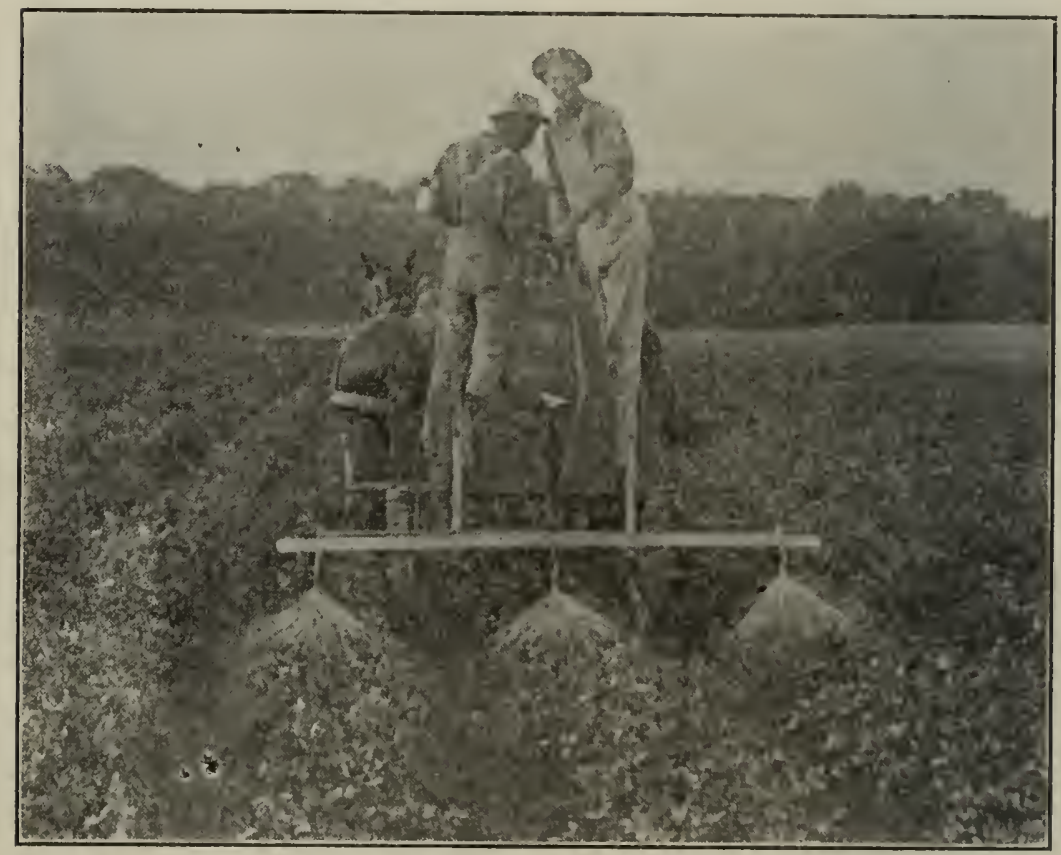

FIG. 36-HOME-MADE SPRAYING MACHINE

tance in the prevention of cliseases, but thorough spraying may frequently save the crop. The soil upon which the celery is grown should be kept in a sanitary condition by removing all diseased plants and refuse from the field after harvesting each crop. The usual method is to plow under all refuse matter and abandoned plants, entire crops that are badly infected by disease being frequently treated 
in this manner. This is an easy way to dispose of the refuse, but at the same time a dangerous proceeding if the land is to be devoted to celery the following season.

Pithiness of Celery.-The term "pithy" is employed to designate any form of soft or hollow stem in the mature celery plant. In a bed of celery plants there are frequently a few of a bright green color which outgrow the others and usually have hollow stems. These rank-growing plants are called "sports" or "rogues," and they can generally be detected when the plants are removed from the plant bed. Seed from a poorly-selected strain of celery will frequently produce a large percentage of plants that do not differ in appearance from the others, but which develop pithy or hollow stems during the growing season.

A special strain or type, such for example as the Golden Self-blanching variety, is obtained by crossing and a certain number of the plants are constantly reverting to the original parent types. In order to keep the strain pure it is necessary that the seed growers should continually cull out all plants that do not conform to the desired type. The French growers of celery seed have attained a high degree of perfection in maintaining pure strains, and until it has been shown that American-grown seed will produce as good results as the French it will be desirable to plant only the imported article. At the present time about 85 per cent. of the Golden Self-blanching celery seed used in America is produced in France and adjacent territory. Seed grown 
in Prussia, Denmark, and England has given very unsatisfactory results, frequently one-half of the plants being either hollow, pithy, or untrue to type. A strain of French-grown celery seed known as Gilt Edge or Originators Golden Self-blanching has frequently shown a trueness to name and type of IOO per cent. As a rule the price of first class French grown seed is considerably higher than that of American seed, but, for the present, it is well worth the difference in cost. American-grown seed of White Plume and also of a number of the large growing green varieties appears to be giving as good satisfaction as any other.

During recent years a number of experiments have been conducted at the Maryland station to determine the cause and remedies for pithiness in celery. ${ }^{1}$ In all of these trials the plants grown from French seed gave the lowest number of pithy, hollow, and green stalks, no imperfection whatever being found in several cases. In these experiments, shading and several special cultural features were introduced, but it was clearly shown that the fault was primarily with the methods, or lack of methods, in growing the seed. Seed grown from pithy plants produced as high as Ioo per cent. of similar character, while that from solid plants gave a large percentage of perfect type. Many thousands of seeds are produced by a single plant, and one pithy seed plant in many would be sufficient to lower the grade of the entire lot of seed.

1 Maryland Agr. Expr. Sta. Buls. Nos. 83 and 93. 
True pithiness in celery is similar to a disease in that it may frecutuently be prevented by proper cultural conditions. Recent observations have shown that either too rank growth in the seed-bed or a severe check will increase the percentage of soft stems. If the celery is allowed to remain too long upon the ground after having been blanched, the outer stems have a tendency to become pithy, although the heart of the plant may not be affected. The pithy development of the outer stems is usually accompanied by a rapid enlargement of the fleshy root as a natural result of the maturing of the plant and the storing of nourishment to be used the following season in the production of seed.

General Suggestions.-It will be observed that the liability of injury from celery diseases is clue largely to inherited tendencies, and that all conditions must be reasonably favorable before the disease will develop. Keeping the crop in a vigorous growing condition is always advisable, and the use of fungicides as a preventive measure is recommended wherever practical. It must be borne in mind that spraying will be of little service unless begun before the appearance of any discase, and that the solutions must be applied frequently and to every part of the plant. 


\section{CHAPTER X}

\section{Insects and Other Animals Injurious to Celery}

THE fact that the taste for celery has to be acquired may account, in a measure, for its having so few insect and other enemies. The unbleached stems of celery have a strong aromatic flavor which acts as a repellent to protect the plant. Celery being a comparatively new garden crop, may partially account for the small number of its enemies, but the list of species that feed upon it is constantly increasing. Growers should be on their guard to detect any insects injuring celery, and if doing any considerable damage, a report, together with live specimens, should be sent to the state experiment station or to the Bureau of Entomology of the Department of Agriculture at Washington, for information regarding the best methods of combating the pest. Most insects that prey upon this class of plants, spend the winter under refuse in the garden or celery field, in the surrounding weeds, and along fences. Every possible means should be employed to destroy the hibernating insects and prevent their appearance in increased numbers the following season. It is not practical to apply poisonous solutions to the growing celery, except while the plants are young, and hand picking is generally recommended for destroying celery-feeding insects. 
Grasshoppers.-During the early growth of the celery, the plants are frequently attacked by grass. hoppers. These insects are especially injurious when the celery is planted near meadows, as they are liable to attack the celery plants after the hay has been harvested. Where no fowls or live stock can possibly be injured, the grasshoppers may be poisoned by means of wheat bran, to which there

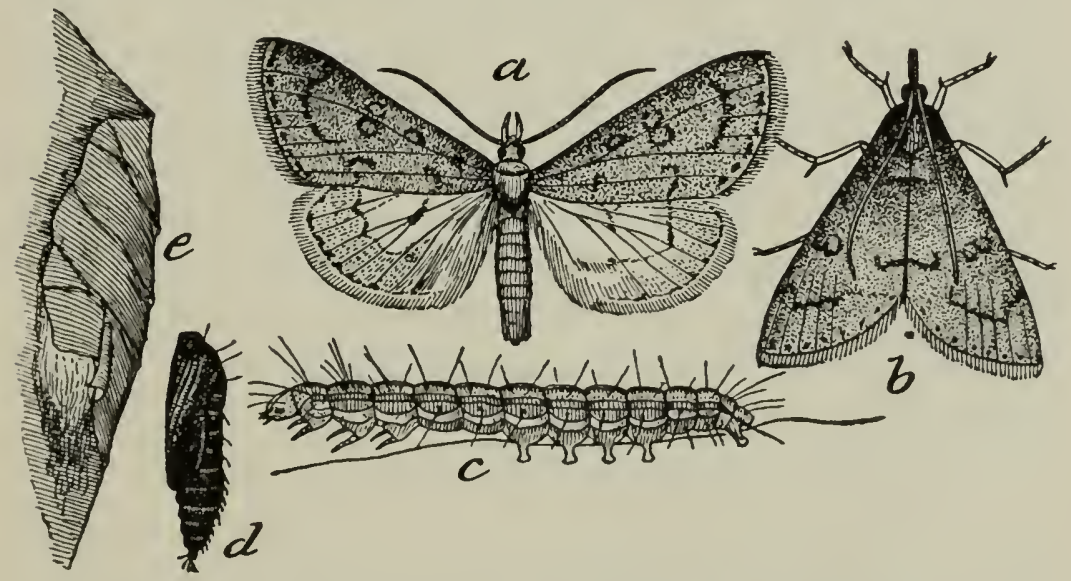

FIG. 37-CELERY LEAF-TYER (Phlyctaenia ferrugalis)

$a, b$, adult moth; $c$, larva; $d$, pupa; $e$, leaf drawn together by larva (Redrawn from Farmers' Bulletin No. 148)

has been added molasses and water with sufficient Paris green to give the mixture a slightly green color.

The Celery Leaf-tyer (Phlyctaenia ferrugalis).This insect frequently becomes troublesome as it not only destroys the leaves by eating them, but also by spinning a web and tying them together. The leaf-tyer is well distributed and may at any time appear in sufficient numbers to be a pest in the 
celery fields. Hand picking has been found satisfactory for keeping this insect under control, but should they become very numerous it may be necessary to trap the moths by means of open lamps at night. Spraying with arsenites might be practiced in cases where the larvae have become very plentiful, but the solution should be so applied as to cover the under side of the leaves where the insects feed.

The Celery Caterpillar (Papilia asterias).-This is the most conspicuous of the celery insects, and perhaps the most harmful. It feeds upon the leaves and a single larva will strip the foliage from a plant in one or two clays. Owing to its size and yellow color, with black transverse bands, it is easily seen against the background of green leaves. The celery caterpillar does not appear in large numbers and hand picking will control it.

The Zebra Caterpillar (Mamestra picta) ${ }^{1}$.- This insect is much smaller than the regular celery caterpillar but fully as striking in appearance. It is often quite abundant, but is easily recognized and can be controlled by hand picking.

The Tarnished Plant-bug (Ly'gus pratensis) ${ }^{1}$.This insect is quite small while young, being about one-twentieth of an inch in length, of a yellowish green color, which changes to a faded yellow or a dull brown when fully grown. As a preventive, keep the celery well cultivated and free from weeds. In the autumn remove all trash from the soil under which the insects can pass the winter. A good remedy in addition to frequent clean cultivation is kero-

' U. S. Dept. of Agr., Bureau of Entomology, Bul. No. 43. 
sene emulsion, but it will be necessary to also treat the surrounding weeds as well as the celery.

The Carrot Rust Fly (Psila rosae) ${ }^{1}$.-This insect, which ordinarily works upon carrots, has recently been reported as injurious to celery in New York State and Canada. The larvae seemed to begin eating into the thick part of the root when the plant is about half grown, injuring the growth and rendering the plant unfit for market.

The Celery Looper (Plusia simplex) ${ }^{1}$.-The larvae of this insect feeds upon the leaves of the celery, and in appearance it is similar to the cabbage looper. The color is a pale yellowish green, and it is about $\mathrm{I} / 2$ inches in length when fully extended. Poultry are efficient at catching the celery looper in the larva stage. Dusting the plants with plaster or air-slaked lime and Paris green mixed at the rate of $1 / 2$ pound of Paris green to 20 pounds of plaster will generally prove effectual.

Mice and Rats.-Field mice have been known to injure celery, especially while it is being blanched with boards. Rats will damage celery in the storage house or pit by working among it and sometimes eating the stalks and roots. As a rule rodents will not eat celery until other foods become very scarce and they damage the stored crop more from breaking the stalks, making nests in the covering materials, and by burrowing holes which let in cold air and cause the celery to freeze during the winter. Catching in traps and hunting with dogs

\footnotetext{
1 From Chittenden in U. S. Dept. of Agr. Bul. No. 33, Bureau of Entomology.
} 
are about the only safe remedies for mice and rats in the celery storehouse or pit. Poisoning should not be resorted to under any circumstances, as the entire stored product is liable to be ruined by absorbing the odors from the rodents' dead bodies.

Poultry.-As a rule chickens will not molest celery except late in the autumn when other green foods become scarce. During the growing season chickens are a benefit as they keep the celery plants free from insects. Ducks and geese should be excluded from the celery field. They very quickly acquire a taste for celery and will soon destroy the plants. 


\section{CHAPTER XI}

\section{Blanching}

IN its original wild state the stems of celery are tough, full of woody strands, of rank flavor, and green in color, being similar to the outside stems or trimmings of our cultivated varieties. The object of blanching is to remove the green coloring matter and to secure leaf-stalks that are free from woody strands, crisp, tender, and having an agreeable flavor. The cultivated varieties of celery are divided into two classes: those that are in a measure selfblanching, and those from which the light must be entirely excluded in order to blanch them. The selfblanching type is well represented in White Plume and Golden Self-blanching varieties, and the nonblanching type by such varieties as Giant Pascal, Giant Solid, and Boston Market.

Blanching may be accomplished by any method whereby the light may be excluded, and by allowing growth to proceed in the dark. Blanching destroys the green coloring matter in the stems that are already grown, and at the same time prevents the formation of coloring matter in the stems that are produced during the blanching process. A large portion of the edible part of the self-blanching varieties is produced during the blanching period and as a result is entirely free from the rank flavor caused 
by the presence of the green coloring matter. The method of blanching to be employed must be determined largely by circumstances and the time when the crop is to be used. If for early use or marketing, the blanching must be completed where the plants are grown; but if the celery be for winter use the blanching may take place after the crop has been removed from the field and placed in storage. When planting for early use it is desirable to choose one of the self-blanching kinds, such as may be easily blanched.

Blanching by Means of Boards.-For completing the blanching of the self-blanching varieties the method in most general use consists of setting I2inch boards on edge along both sides of the rows. In localities where the cost of lumber is too great for practical use, the blanching can be accomplished by banking with earth. The boards employed for blanching purposes should be I inch thick, about 12 inches wide, and of any desired length that can be easily handled. The cheaper grades of lumber will answer the purpose, but new lumber is liable to impart an unpleasant flavor to the celery. In placing the boards in position, slip one edge well under the outside leaves of the plants, then bring this edge upward to a vertical position along the row, having another board at the same time placed on the other side so that when the loards are in position there will be as little space between them as the thickness of the plants will permit. These boards may, when used on a small scale only, be fastened in position by means of stakes driven in the ground, by nailing 


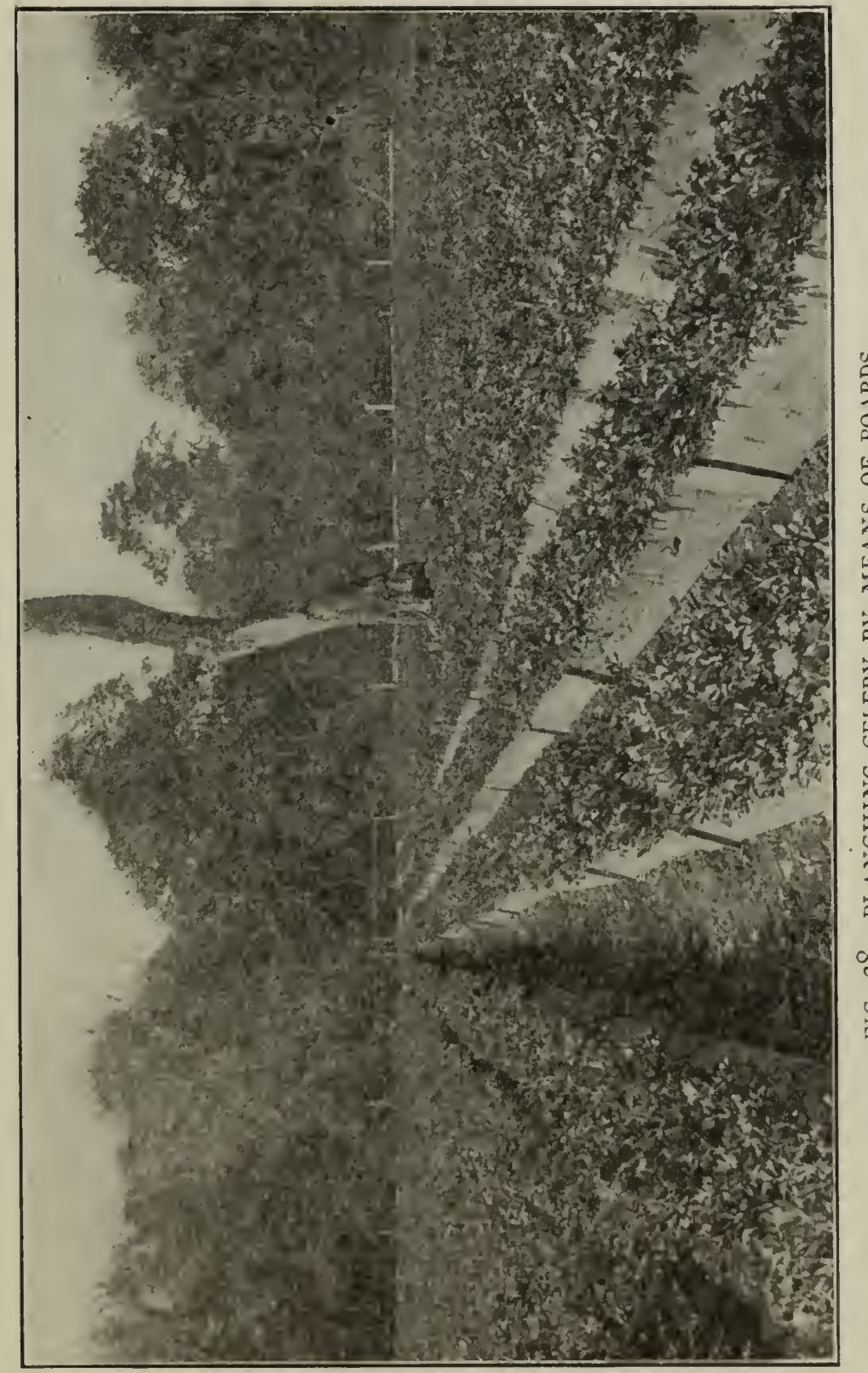

 
short pieces of lath across the top every 6 or 8 feet, or by notched sticks placed over the tops of the boards. A better method of holding the boards to. gether is by the use of double hooks or spanners nearly 8 inches in length and made of heavy galvanized wire. These spanners are slipped over the top edges of the boards at intervals of a few feet, and the plants are rigid enough to keep the boards in an urright position. After the boards are all in place it is a good plan to run the double celery hiller

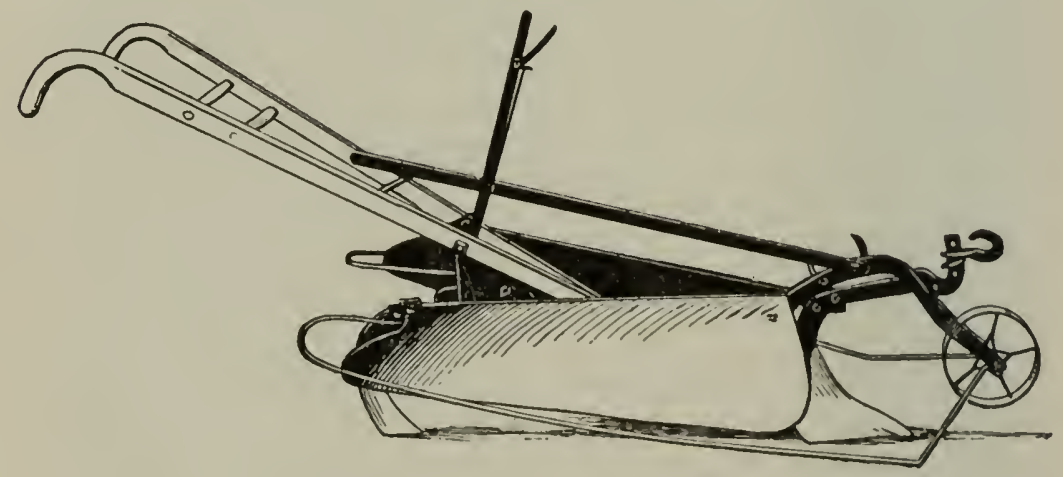

FIG. 39-PLANET JR. DOUBLE CELERY HILLER

between the rows and throw a little soil to the lower edges of the boards in order to close any openings. For illustration of the celery liller see Fig. 39.

Time Required for Blanching.-Ten to twenty days will be required to complete the blanching of the early varieties, but the boards must be kept in position until the crop is removed from the ground, after which they may be used again two or three times during a season. If the celery is allowed to remain in the boards too long after it has reached a marketable stage it loses in weight and flavor and is 
liable to become pithy or be attacked by diseases. This is especially true during the earlier part of the season while the weather is warm. At the close of the season the boards should be promptly hauled to some well-drained location and piled flat, in large piles that are raised from the ground, with strips inserted at every fourth or fifth course for ventilation. The top courses should be laid roof fashion to shed off all rain, and if cared for in this manner they will last from Io to I5 years. In Florida, what is known as "pecky" cypress, or cypress which has the appearance of having been worm-eaten, is used for blanching purposes. This class of lumber is practically unfit for other purposes, but is as good for blanching celery as sound lumber, and as it comes from the heart of old trees it is very durable when exposed to the weather. The prices of "pecky" cypress are very low as compared with those of other lumber such as can be used for blanching celery.

Banking with Earth.-Banking with earth is the only practical means of blanching celery on a large scale in localities where lumber is too expensive, and as a rule this method will give the best results in home garden culture. (See frontispiece.) In the North, banking with earth is especially desirable for the handling of that portion of the crop which cannot be marketed before the first severe frosts. In case of a freeze the boards offer but slight protection, while the celery that has the earth well drawn up to its tops will not be injured by a temperature $3^{\circ}$ or $4^{\circ}$ below freezing, if only for a short 
period. Celery that is banked with earth will invariably possess a better flavor than that blanched in any other manner. Where the plants are set in single rows the soil can often be partially thrown up by means of a plow, or a celery hiller. (Fig. 4O.)

There are several makes of celery hiller, but they all work upon the principle of a diagonally set sur-

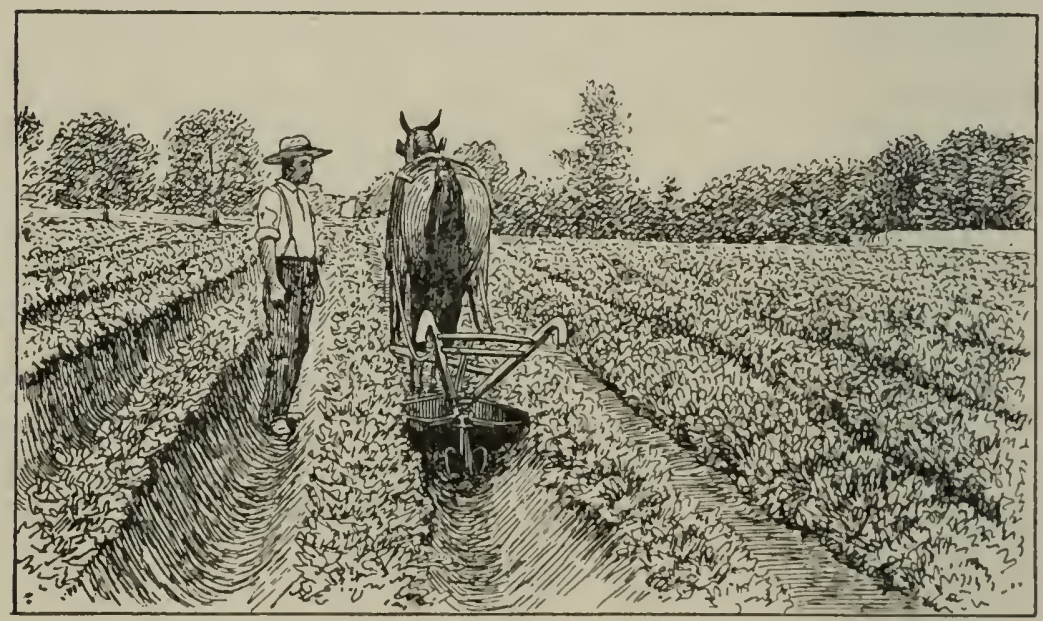

FIG. 40-BLANCHING CELERY IVITH EARTH. PLANET JR. CELERY

HILLER IN OPERATION

face to throw up the soil. Before the plow or banking machine is used a small amount of soil must be placed around the base of the plants to hold them in an upright and compact position. This process is generally termed "handling," and is greatly facilitated by having the soil in the middles loosened with a harrow tooth cultivator in order that loose earth will be readily available.

The plants may also be held together for banking by tying them with paper twine. Instead of tying 
each plant by knotting around it a short piece of string, fasten the string around the first plant in a row, then pass to the second plant and around it without cutting or breaking the string; while the string is being carried around the plant with the right hand, the outside leaves are brought up together with the left hand and held in place by the string, and so on from plant to plant until the whole row is held up without breaking the string and by tying it at the ends of the row only. The work of tying is greatly facilitated by strapping to the right forearm a tin can in which the ball of cord is placed, the inside end of the string being delivered through a hole in the bottom of the can from which it passes between the thumb and finger and around the plants. The paper twine is manufactured by twisting a strip of paper and it will go to pieces as soon as it becomes thoroughly moistened, and for this reason offers no resistance to the growth of the celery, but merely holds the stalks together until the earth is thrown around them and compacted.

Another method for holding the celery in position for banking with earth, is by setting up boards along the row, as for blanching with boards, then after the earth has been thrown up against the boards they are lifted out and removed. Where celery planted in solid beds is banked with earth, the entire amount of soil required must be shoveled in by hand, but the work is greatly facilitated by tying the plants or by setting boards temporarily between the rows and then removing them after the earth has been thrown in. 
Blanching with Tile.-A very satisfactory method of blanching celery on a small scale is by means of ordinary unglazed farm drain tiles of 3 or 4 inches

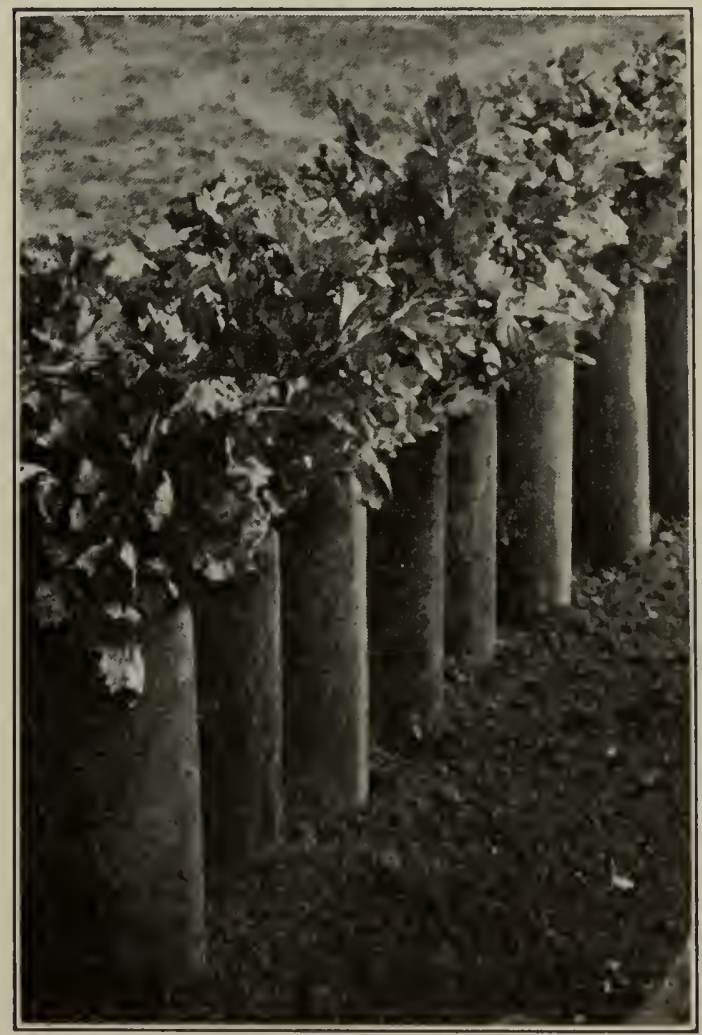

FIG. 4I-BLANCHING CELERY BY MEANS OF DRAIN TILES inside diameter, placed over the plants after they have become almost fully grown. To facilitate the work of placing the tiles over the plants, some of the outside leaves should be pulled away and the main part of the plant loosely tied together by means of paper twine. The tiles will cause $\mathrm{the}$ 1 e a ves all to draw up ward over the tops of the tiles, forming a screen to shut out the light from the interior. This system of blanching celery is very desirable on account of its cleanliness, as the product will require very little washing before marketing. When tiles are used for blanching celery during warm weather, a small opening should be left at the bottom in order to provide a cir- 
culation of air through the tile, otherwise decay may follow as a result of insufficient ventilation.

Various Methods of Blanching Celery.-Another method of blanching is by means of straw or leaves, but this is objectionable as the material used generally imparts an undesirable flavor to the celery. The use for blanching purposes of any material that is in process of decomposition will cause the loss of the crop from diseases. Wrapping paper is sometimes employed for blanching celery on a small scale by placing two or three layers around the plants and fastening by tying with string or with rubber bands. This method of blanching is not highly recommended, as it does not produce a good grade of celery.

Blanching for Winter Use.-Celery that is to be stored for winter use will require very little blanching in the field, and that which is blanched least will keep best in storage. While growing in the field the plants should have sufficient soil placed about them to insure an upright, compact growth. If the celery is wanted for use during the early part of the winter, it will be necessary to carry the blanching process further than if it is to be kept until later. 


\section{CHAPTER XII}

\section{Storing Celery}

While in storage celery should be kept cool, without freezing, rather moist but well ventilated, and where it will be accessible for removal as required for use. Celery should never be stored in cellars or pits where there are decaying vegetables or roots, as it is very susceptible to any odor and the flavor will be impaired. No tar paper, green lumber, or decaying vegetable matter should be used in the construction or around the storage cellar, pit, or trench. Where it is necessary to supply artificial heat in order to prevent the celery freezing in the storehouse, care should be taken that none of the smoke or gases from the heater escape within the enclosure. The use of oil lamps and stoves or the building of an open fire in the storehouse will impart an umpleasant flavor to the celery. If artificial heat is absolutely necessary it should be supplied from a tight stove attached to a substantial flue or chimney, or in places where a steam or hot water heating plant is being used for heating greenhouses or the dwelling a few pipes can be placed in the celery storehouse and controlled by valves.

Storing Where Grown.-The plan of storage usually adopted where celery is produced on a small scale for home use, is to bank with earth and cover where grown. Late in the season the earth is 
banked well up around the plants, and as the weather becomes colder, the soil is brought up to the tops of the plants so that only a few of the tips of the leaves will be exposed. After a few days the ridge is crowned by a covering of straw, leaves, or corn fodder, held in place by boards or earth. When the ground begins freezing the entire ridge should be covered to a depth of 3 or 4 inches with coarse stable manure or any material that will prevent freezing. Celery will withstand considerable frost, but its keeping qualities will be impaired if the tops become frozcn. The celery can be removed from the ridges as required for use, but will be quite inaccessible during a portion of the winter.

Storing in Temporary Pit or in Vacant Hotbed.The celery intended for winter use may be partially blanched in the field or garden, and the plants removed with a part of their roots attached to the storage pit or cellar. A permanent hotbed forms a convenient celery storage by cleaning out the pit and placing 4 or 5 inches of fine loose soil in the bottom. The roots of the celery may be bedded in this loose soil quite close together, so that the plants will be almost touching when in place, or about 4 inches in each direction. After the celery is all in place, a covering of boards should be put on and the bed well ventilated until the weather becomes quite cool, when a covering of corn fodder, leaves, pine needles, or coarse manure should be added. If a hotbed is not available for the storage of the home supply of celery, a pit may be made by excavating a trench 18 inches deep, 4 to 6 feet wide, and 
of any desired length, setting the celery in the same manner as deccribed for the hotbed. To determine the size of the pit, divide the number of plants to be stored by sixteen, and the result will be the required space in square feet. After the celery is in place it should be watered and allowed to remain exposed until the tops are no longer wet. A twelve-inch board should then be placed on edge along one side of the

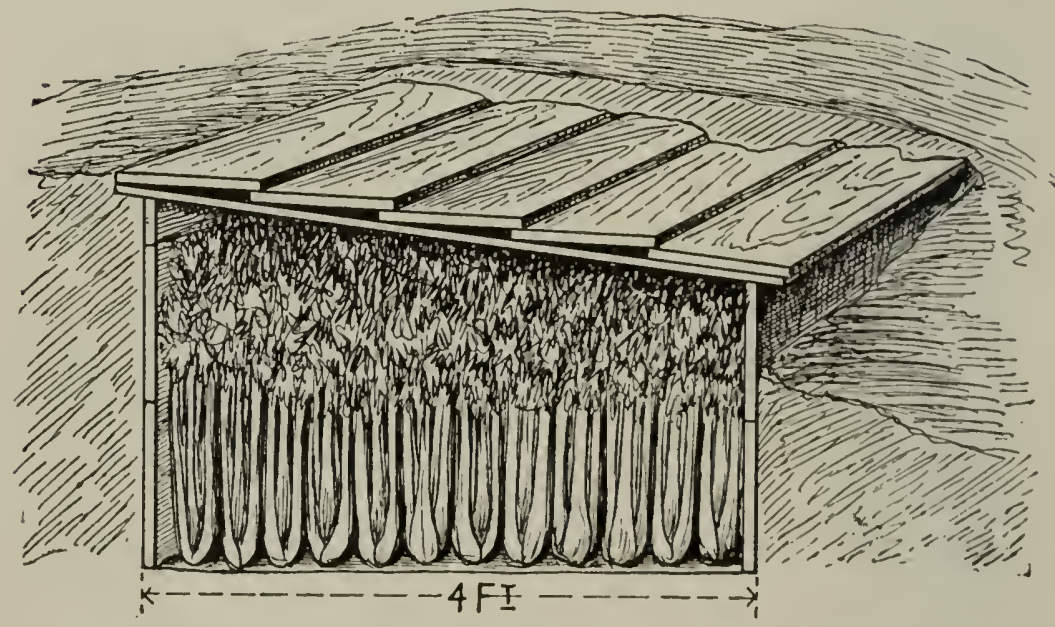

FIG. 42-TEMPORARY STORAGE-PIT FOR CELERY

pit and short pieces of scantling placed across the pit at intervals, with one end resting upon the board and the other on the ground. A roof of rough boards should then be put on, running lengthwise of the pit and overlapping to shed water. A layer of leaves or straw should be thrown over the board roof and a covering of earth added. The pit should be provided with two or more openings for ventilation and these should be tightly closed during cold weather. 
Storage in cellars will be found satisfactory provided the temperature can be kept low enough and proper ventilation maintained. Place 3 or 4 inches of loose soil upon the cellar floor and set the plants upright, quite close together, with their roots firmly bedded in the soil. The soil around the roots of the cclery should be well watered, care being taken that the tops do not become wet. During the winter the celery should be watered only as required to prevent wilting and the water applied to the soil only. From the time the celery is placed in storage the temperature should be kept low by free ventilation during the night and closing the openings during the day.

Trenching for Late Autumn Marketing.-Where it is desirable to hold a portion of the field crop of celery for late autumn marketing, this may be accomplished by lifting the bunches, with a portion of their roots attached, and placing them quite close together in shallow trenches. The trench may be prepared by hand or by a two-horse plow, turning out a double furrow, and either clean out or break any lumps that may remain in the furrows. As a rule the trenches are located in the field between the celery rows, a trench being provided for each ten or twelve rows. By another method two lines of twelve-inch boards are set on edge, 18 inches apart, and held in place by stakes. In either case the celery is brought from both sides and packed in the trench, or enclosure made by the boards, and the earth thrown well up around it. The boards may be removed and used in another place, but it is rather more desirable to have them remain until the 
celery is required for marketing. A covering material of some kind should be provided and this kept alongside of the trenches ready for immediate use in case of severe frost or slight freezing. As a rule storing celery by trenching is practiced where it is

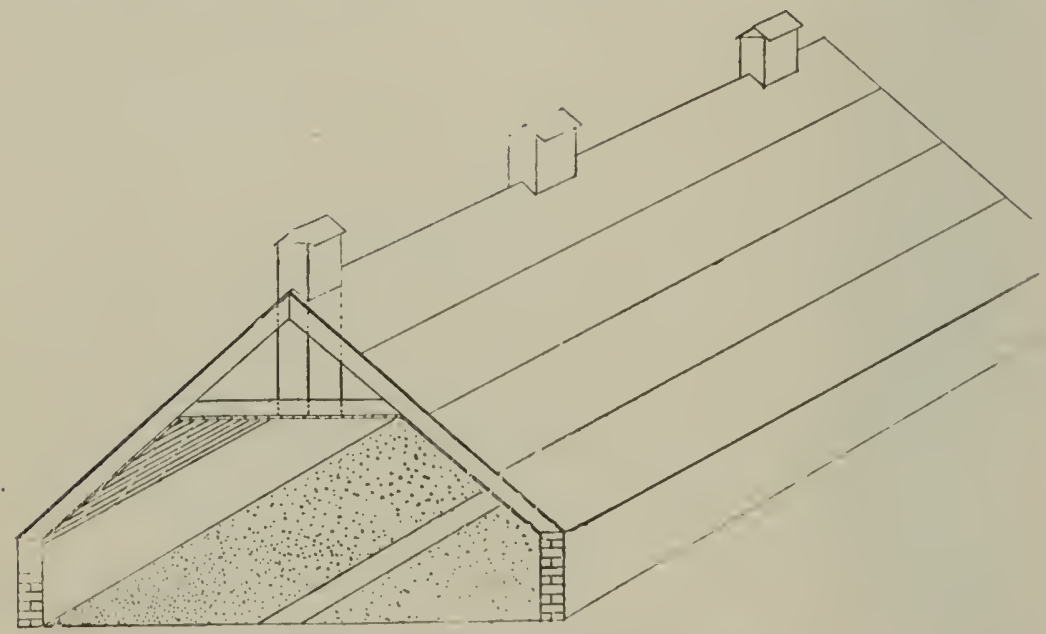

FIG. 43-C.EIERY STORAGE-HOUSE

desirable to heid î for a short period only, although with proper covering it may be kept in this manner for several weeks.

Storing for Late Marketing.-Almost without exception the larger northern growers have found it unprofitable to store celery for late keeping, and those who still adhere to the practice do so in order that they may control and supply a special trade. Even under special circumstances there is only a moderate profit in storing for late marketing. The best form of storage house is a broad and long structure (Fig. 43) with low side walls and a roof coming almost to the ground at the caves. The walli 
should be constructed of concrete or brick and the roof made very tight to keep out frost. The roof portion should also be ceiled to form a double construction with air space between. Large doors should be provided at both ends, and if so arranged that a team of horses can be driven through the work of unloading the celery will be greatly facilitated. The earth floor of the storage house should have a covering consisting of 4 or 5 inches of loose soil in which to pack the roots of the celery. It is desirable to have the storehouse divided lengthwise into beds 6 or 8 feet in width by means of six-inch boards on edge, raised 3 or 4 inches from the soil and fastened to stakes. These lines of raised boards assist in holding the celery in an upright position and increase the circulation of air through it.

Methods of Handling Celery for Storing.-Where any considerable quantity of celery is to be stored, everything should be in readiness beforehand so that the crop may be brought in quickly. In the field the plants should be loosened as required so that it may be easily pulled up by hand; for any quantity less than 4 or 5 acres of celery this work can be done with spades, but on a larger scale a machine for digging should be used. The digger most commonly employed consists of a steel blade 5 or 6 inches in width, $1 / 2$ inch thick, and sharpened on one edge. The cutting blade should be turned up at the ends, the width between the upturned ends being about 18 or 20 inches. The blade is mounted by means of an axle and two wheels, and must be so arranged that its depth in the soil may be regu- 
lated. Two horses are required to draw the cutting machine in order to straddle the row. The depth to set the cutting blade must be determined by the sound it makes in passing through the roots of the celery, the idea being to sever the roots just at the base of the thick, fleshy root. The method of using the digging machine is shown in Fig. 44.

The celery should be loosened only as removed to the storehouse, as a short exposure to the sun

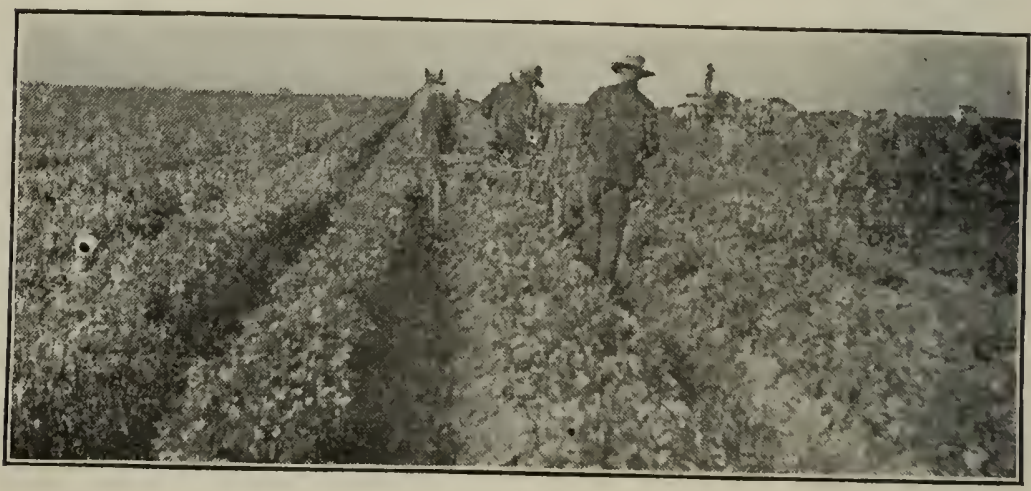

FIG. 44-M ACHINE FOR LOOSENING CELERY FROM THE SOIL

after the roots have been disturbed is ver: injurious and detracts from its keeping qualities. If the celery is not too tender, the handling from the field to storehouse may be accomplished without the use of boxes; otherwise a number of boxes should be provided, each $12 \times 12 \times 26$ or 28 inches in size, constructed of one-inch lumber for the ends and half-inch for the sides and bottom. A wagon with low, broad tire wheels will be found convenient for the transfer. If boxes are not used, the celery should be simply piled upon the wagon platform. 
If boxes are employed, one set may be filled while the wagon is at the storehouse unloading and loss of time will be avoided. In placing the celery in the boxes care must be taken that it is neatly packed with all roots in the bottom of the box. Upon reaching the storehouse the celery is removed from the wagon and placed in piles near where it is to be stored, or if in boxes these can be set near at hand. Beginning at the end of one of the divisions, a small furrow is opened in the soil by means of a spade, and the celery is set lupright in this furrow, and the soil well firmed about the roots. The soil in the storehouse should be rather moist at the time the celery is brought in and it may be necessary to water a little from time to time by inserting the end of a hose between the plants and applying the water to the roots. After the storehouse is filled, constant ventilation should be maintained by means of openings near the ridge, and the temperature should be kept as nearly $36^{\circ} \mathrm{F}$. as possible, care being taken, however, that the celery does not become frozen.

Cold Storage.-Celery may be kept in cold storage for several weeks, but storing in this manner is not profitable on a large scale owing to the space required to accommodate a comparatively small amount of the rough product. Celery that has been iced will not keep so well after its removal from the storage. 


\section{Marketing}

THE general practice at present is to market the crop direct from the field where grown. In the North, the last of the crop may be held for a short time by trenching, but this portion is generally in the cars and on its way to market before freezing weather sets in. Very little of the northern product is available after December I5, and is followed by the California crop which supplies the market until that grown in Florida is ready for use. In this way the marketing period for celery begins about the first week in August. and continues until some time in April.

Methods of Preparing Celery for Market.-Two methods of shipping celery are in general use, the one termed "shipping in the rough," by which the outside leaves only are removed and the bunches shipped withont washing, and the other by which the bunches are trimmed, washed, and tied in bundles of one dozen each before shipment. Celery packed in the rough will withstand long distance shipment better than that which has been trimmed and washed, the ontside leaves helping to keep the inner ones fresh and frec from injury. The rough celery must be trimmed, washed, and bunched either by the commission merchant or the retail dealer, but in either case the celery reaches the customer in a comparatively fresh condition. For 
handling early celery where the distances are not too great it is generally more satisfactory to trim and wash the bunches, as the washing in cold water will freshen the stems and tend to kecp them crisp and tender.

When marketing direct from the field without

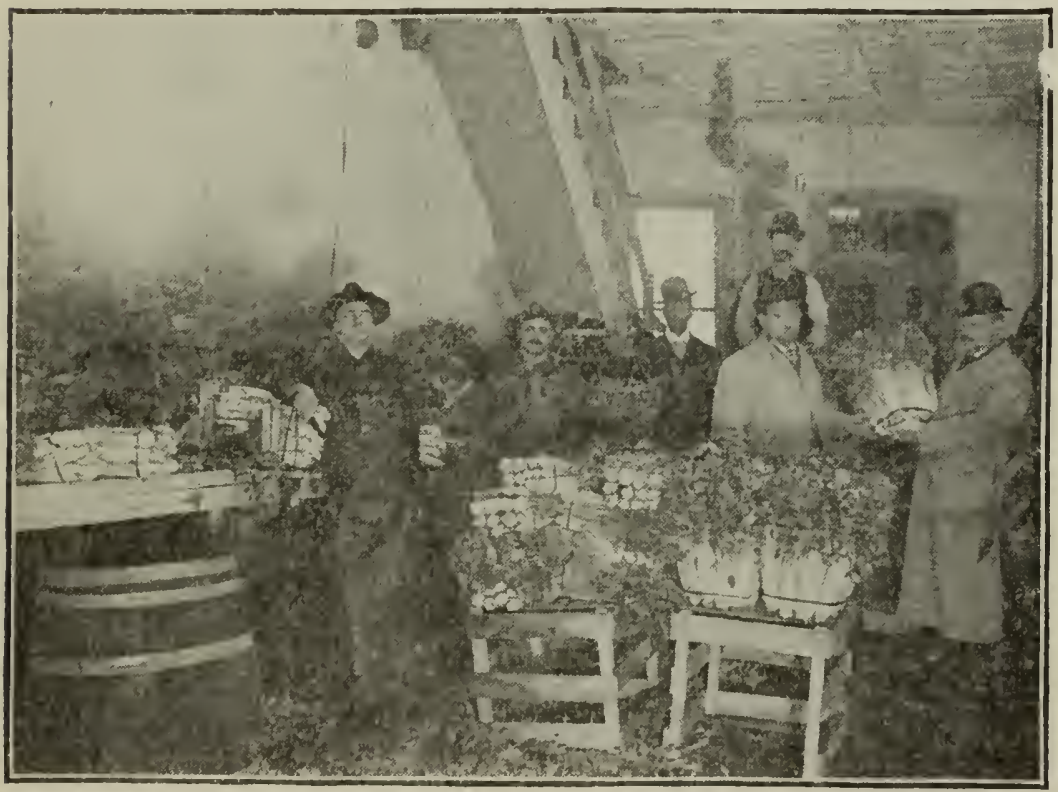

FIG. 45-WASHING AND BUNCHING CELERY IN COMMISSION MERCHANT'S ROOM. CELERY SHIPIED IN THE ROUGH

washing the celery, if banked with earth, is lifted by means of spades or a digger, but if blanched with boards the plants are generally cut a little below the surface of the soil by means of short butcher knives. When rearly for cutting the boards are loosened by removing the wire sparners or the wood cleats and the boards turned down along the 
rows where they serve as walks for the cutters to work upon. The boards should be loosened only as fast as the celery is cut, or at most, but two or three rows ahead of the cutters. In cutting, the plant should be firmly grasped in one hand and the root severed by means of the knife held in the other.

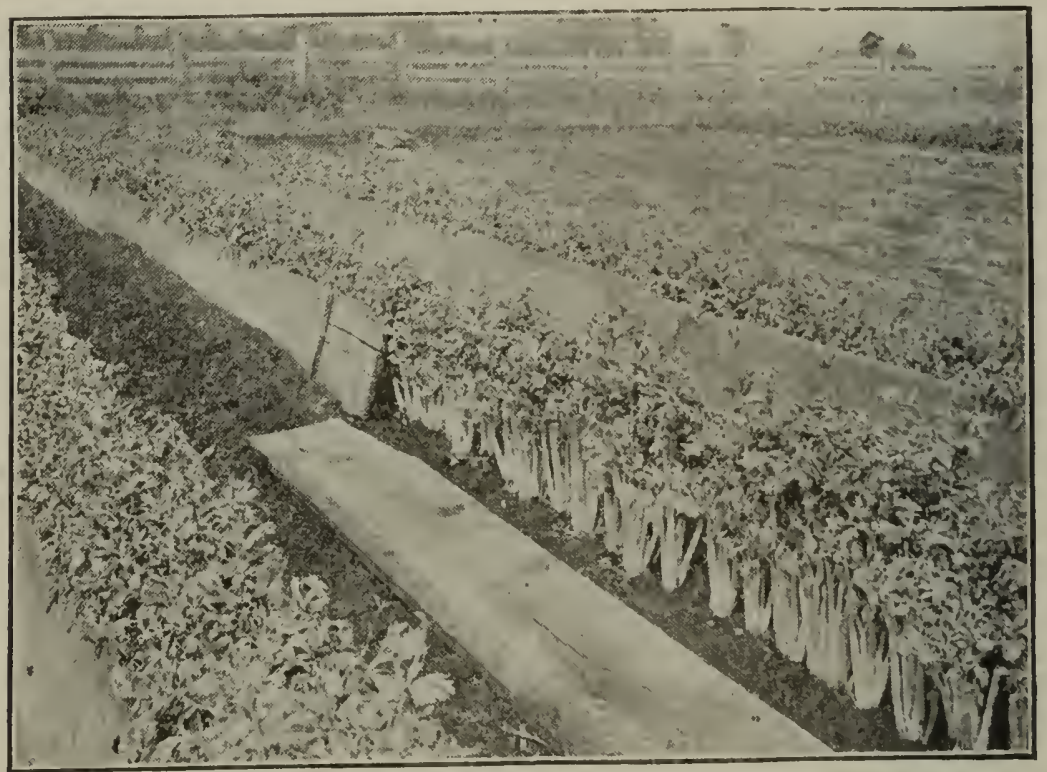

FIG. 46-ROW OF BLANCHED CELERY READY FOR CUTTING

In this way, it is easy to detect any stalks that are hollow or pithy, and these are generally allowed to remain upon the ground. The cutters place the celery in convenient piles ready for the packers, who should follow close behind them. The method of packing is illustrated by Fig. 47 .

Sizes and Styles of Shipping Crates.-The shipping crate in general use, except in Florida, is $24 \times 24$ inclics in size and 20 inches deep, holding from four 
to nine dozen, according to the size of the plants. The bottom of the crate is nearly tight, while the sides and top are quite open, as illustrated in Fig. 48. The top and a part of one side of the crate is left open until it is filled with celery. The packers are followed by the men who nail the crates, and the celery should then be promptly loaded upon

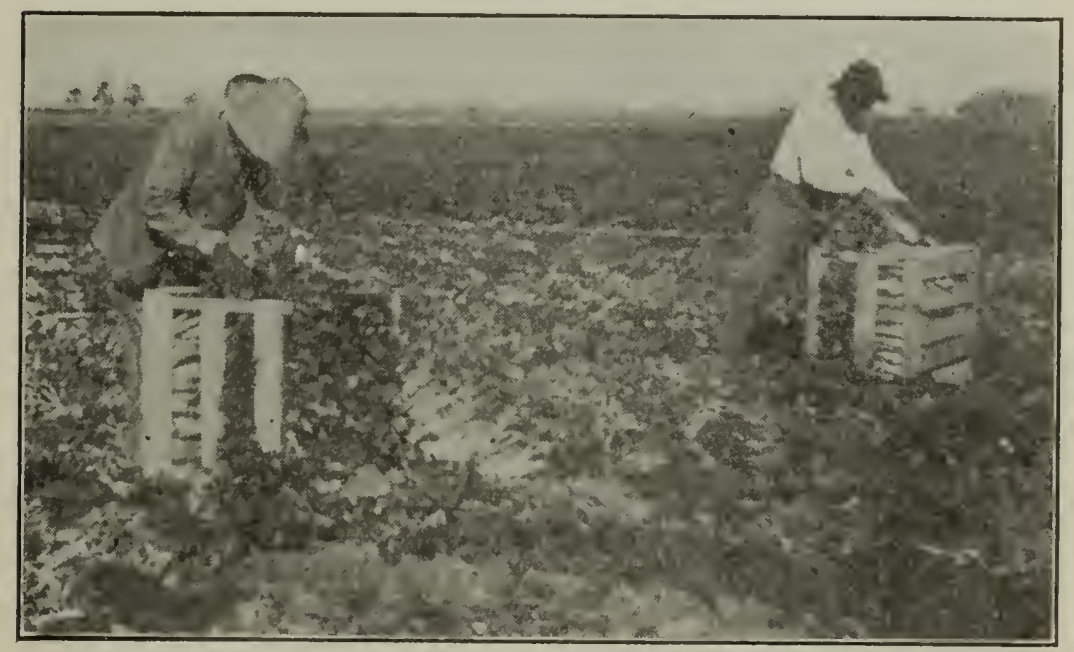

FIG. 47-PACKING CELERY IN CRATES IN CALIFORNIA FIELD

wagons and hauled direct to the car. As a rule the crates are marked before packing in order that no time may be lost in handling. When the shipping season is at its height, the large growers aim to have the celery in the car within two hours after being cut, and often loading several cars in a single day. On reaching the car the crates are carefully placed with small air spaces for ventilation, and packed in this manner the ordinary refrigerator car will hold from 160 to 165 crates. 
The shipping crate used by the Florida growers is 20 inches high, 24 inches long, and II to I 4 inches wide, holding from $2 \frac{1}{2}$ to 4 dozen. The Florida crate is, as a rule, better made than the general crate and requires more care in placing in the car, in order to provide air spaces for ventilation. The crates should be set with the celery in an upright position, and in order that they may not shift in

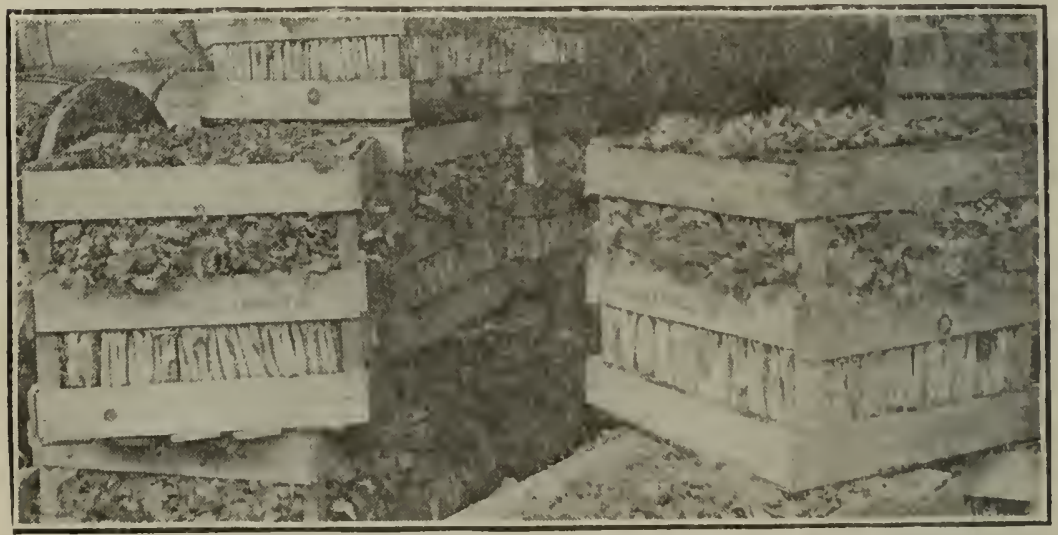

FIG. 48-CRATES OF CELERY SHIPPED IN THE ROUGH

transit it is desirable to place two thin strips of wood across the tops of each row of crates in the car. Upon reaching its destination the celery is trimmed, washed, and bunched in the usual manner.

Washing and Bunching Before Shipment.-IVhen the celery is to be washed and tied in bunches before shipment or hauling to the local market, the greater portion of the root should be left in the ground in cutting. The trimming is usually done in the field, all the inferior outside stems being removed, the root trimmed to a conical shape, 
and a small part of the point evenly cut off. Fig. 50 illustrates proper and improper methods of trimming the roots of celery intended for market. As the celery is trimmed it is placed in boxes or crates and should be promptly hauled to the packing-

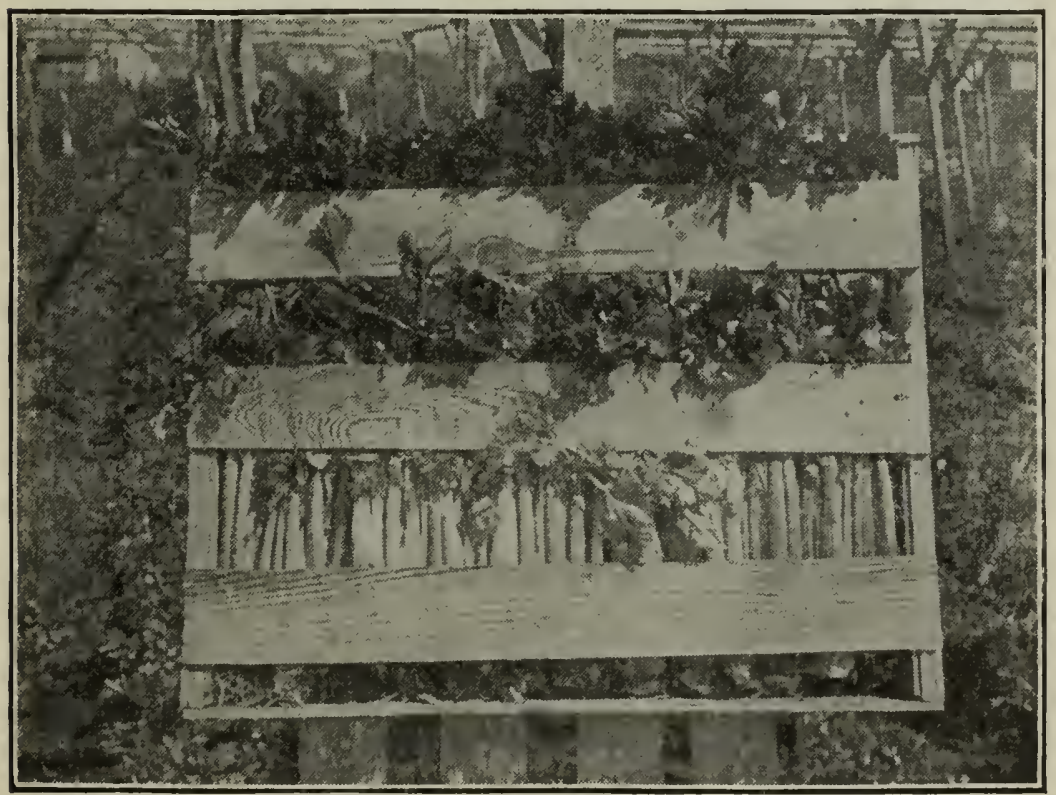

FIG. 49-CRATE OF FLORIDA CELERY SHIPPED IN THE ROUGH

house; if the distance is great the celery should be covered while upon the wagon to protect it from the sun and wind. Celery that has been temporarily stored in trenches is handled in practically the same manner as from the rows.

The celery packing-house in most common use consists of a two or three-room building, with a half-story or loft above for the storage of crate materials Loading and unloading platforms should 


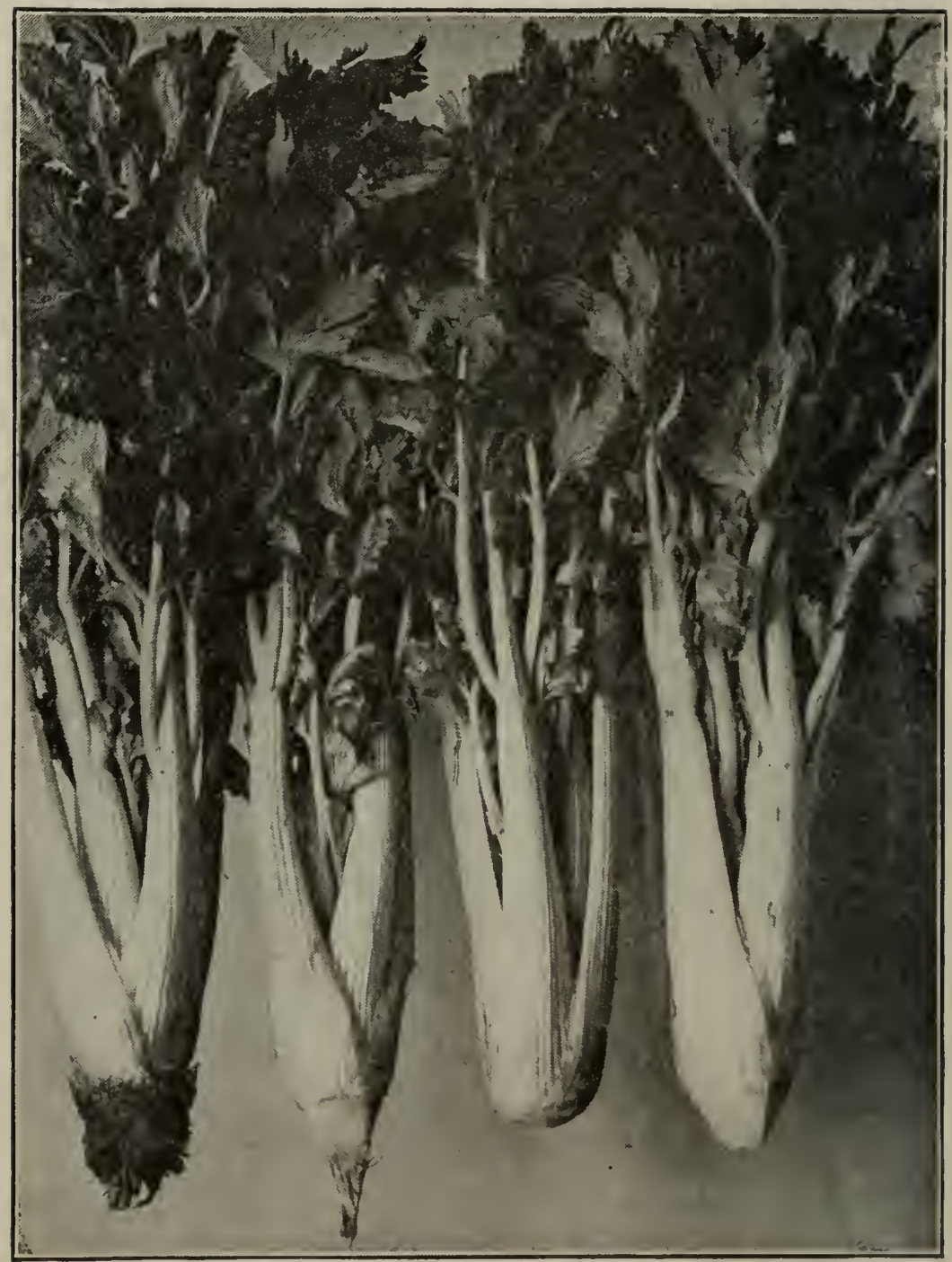

FIG. 5O-CELERY TRIMMED FOR MARKET. THREE ON LEFT IMPROPERLY TRIM MED; ONE ON RIGIIT PROPERLY TRIMMED 
be provided at one side of the building and these should be high enough from the ground for convenience in handling the crates of celery. As the celery is unloaded from the wagons it is taken into the wash room. Some growers employ a washing trough and scrub the celery clean by means of

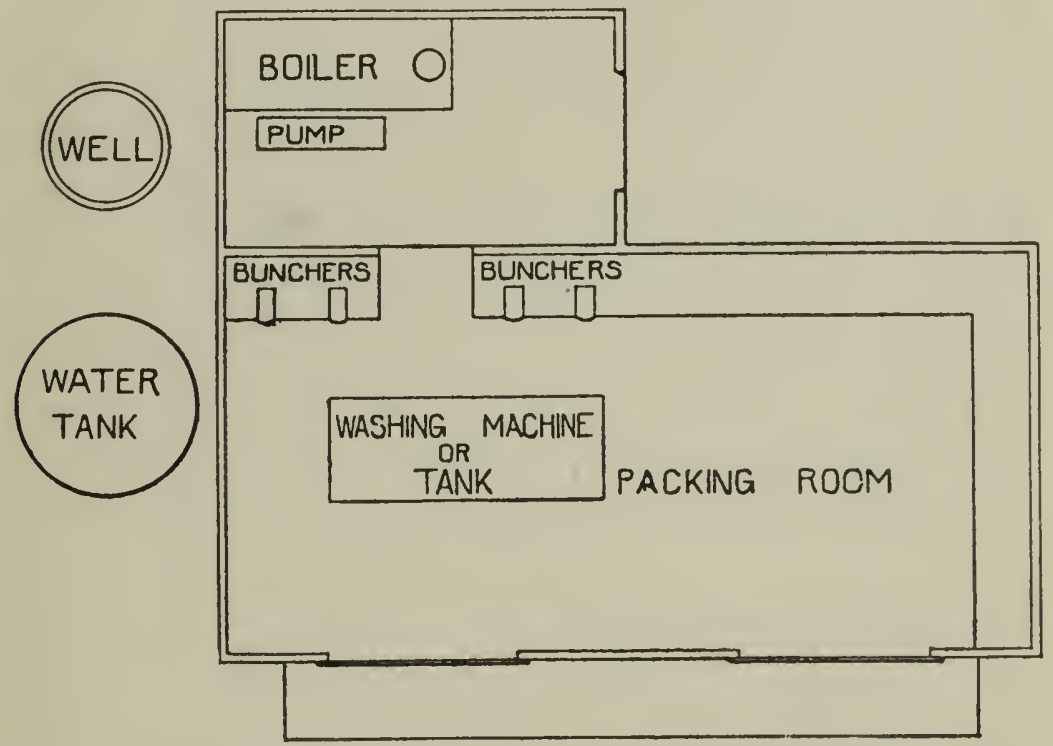

FIG. 5I-FLOOR PLAN OF CELERY PACKING-HOUSE

brushes, but a device with which the celery is placed upon a rack and subjected to a strong spray of water, without brushing, is more desirable.

Construction of Washing Machine.-Where a large trough or tank is in use for hand washing it may readily be converted into a machine washer. It will be necessary to construct a rack from woor slats upon which the celery may rest during the washing process. This rack should only be about 
one-half the width of the inside of the tank, and suspended within the tank at a point about one foot below the top. The rack should be so arranged on rollers or sliding device that it will move readily from side to side of the tank. Directly over the center of the tank suspend an iron pipe having numerous small holes on the under side through which the water is driven in a spray upon the celery. This pipe should have a control valve connecting it direct to the pipe leading to the pump or other water supply. The rack is drawn to one side and the celery is spread upon it; the water is then turned on and the rack shoved backward and forward beneath the spray until the celery is clean on one side; the rack is again drawn to one side and the celery turned, after which it is passed under the spray and the celery removed on the opposite side of the trough. If desirable two racks may be put in and the work carried on from both sides, one rack being under the spray while the other is empticd and refilled. Any grower can construct a machine of this character provided a supply of water under pressure is available. If necessary the water can be collected beneath the washer, passed over a screen or filter, and used repeatedly.

Bunching and Packing.-As the celery is washed it is removed to the packing room where it is graded and packed in bunches containing from $\mathbf{I} 2$ to 16 plants each, according to the size. The work of bunching is greatly facilitated by the cmployment of a device similar to that shown in Fig. 53 by means of which the celery is firmly held while 


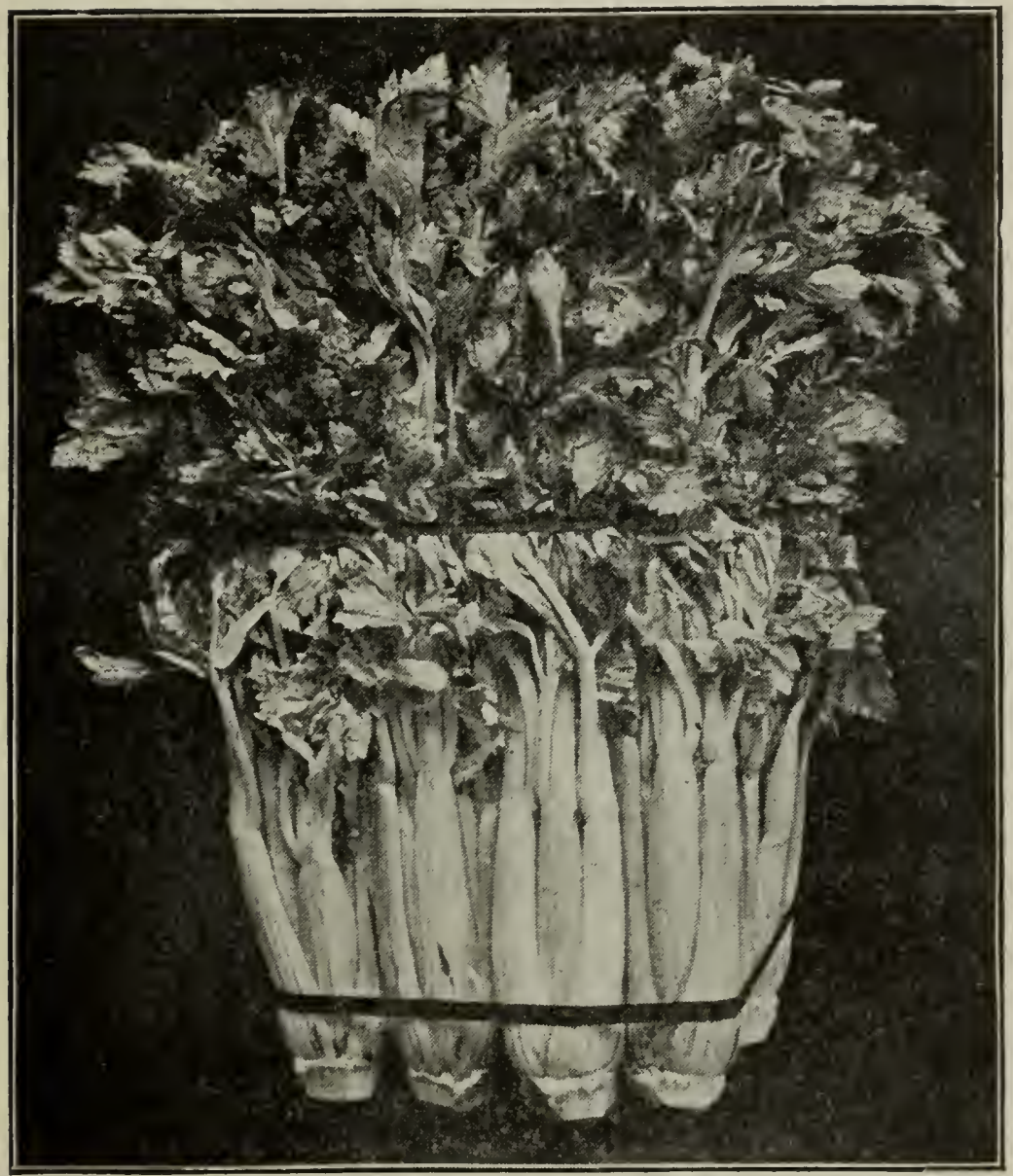

FIG. 52-BUNCH OF CELERY CONTAINING ONE DOZEN PLANTS

being tiecl. 'The tying is done with one-fourth-inch pink tape provided for this purpose, and the bunches are either wrapped separately in paper, or packed in crates that are lined with heavy paper. The crates hold 4 to 6 dozen for first grade, 7 to 9 dozen for second grade, and more than 9 dozen for culls. Throughout the process of cleaning and packing 
the celery should be kept as cool as possible, and the water should be well drained from it before wrapping in paper or packing in boxes.

Sanitary Considerations in Marketing Celery.Very little attention has been given to the sanitary requirements of celery growing and marketing.

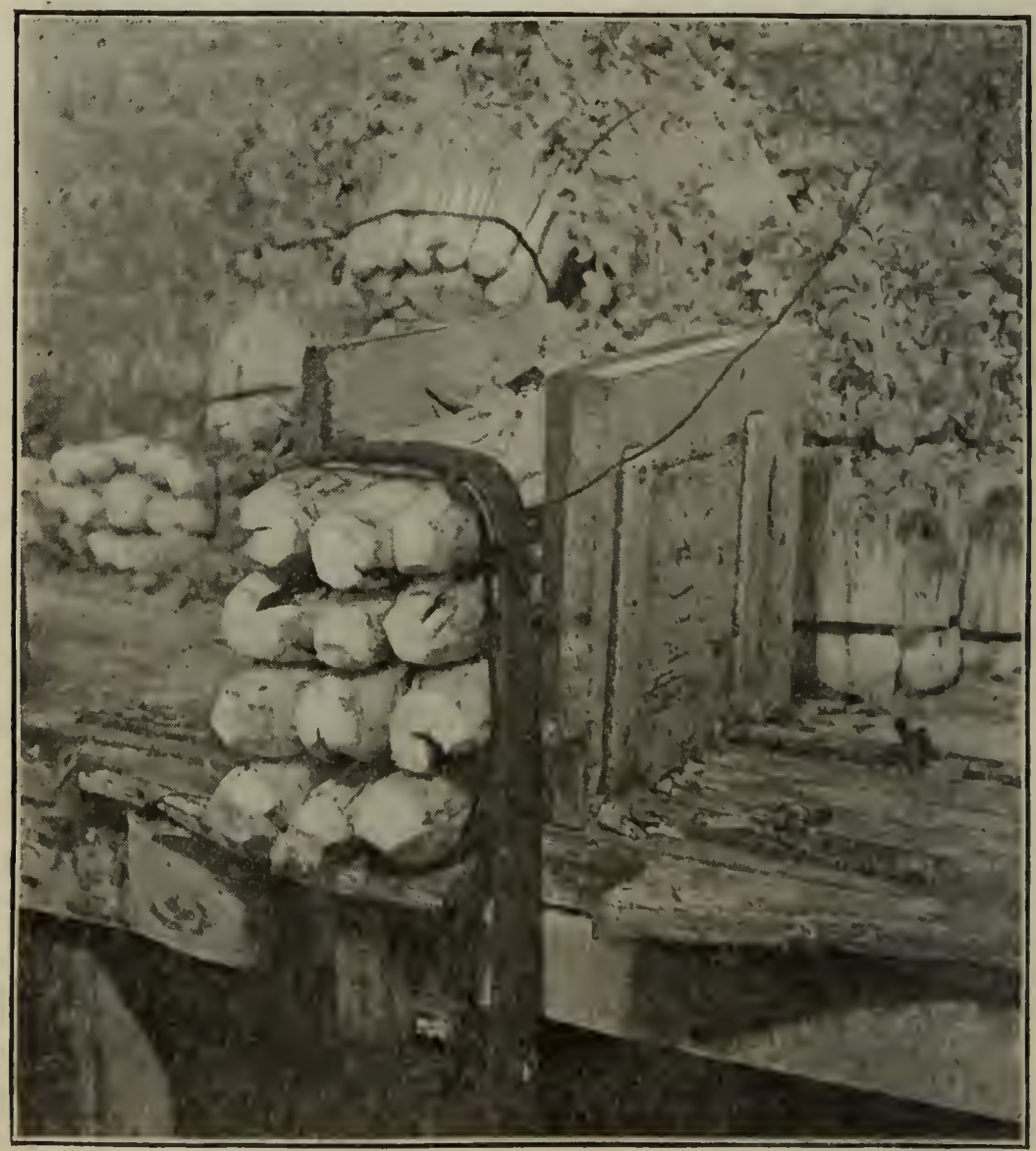

FIG. 53-DEVICE FOR BUNCHING CFLERY

Thumb screws at right permit setting the box at any width for different sizes of celery. Tightening strap is provided for foot pressure. Spool of tape on revolving spindle is suspended overhead 
Growers, shippers, and dealers all lose sight of the fact that the edible portion of celery is constantly exposed to the contaminating effects of dirty wagons, cars, and dusty markets. It is essential that celery should be washed in pure water in order that it may be free from disease germs. Any germ,

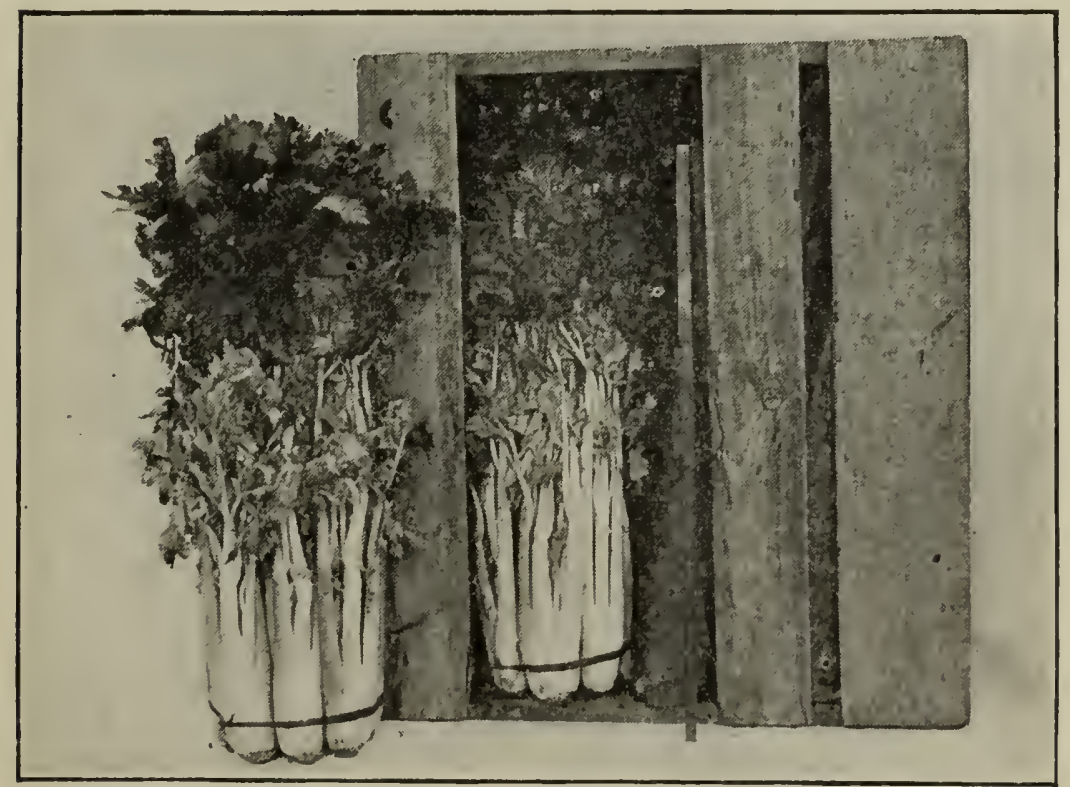

FIG. 54-MICHIGAN CRATE

White Plume celery, washed, bunched, and wrapped in paper before being placed in crate. Note cnormous size

such as that producing typhoid fever, which is usually present in impure water may be readily carried into the digestive system with the celery. The packing-house and its surroundings should be kept clean and all trimmings or other refuse removed before decomposition begins. 
Keeping Celery Fresh While Exposed for Sale.Celery exposed on the market for sale loses its freshness rapidly, and to overcome this many of the growers who market locally supply their dealers with a device intended to keep the celery fresh.

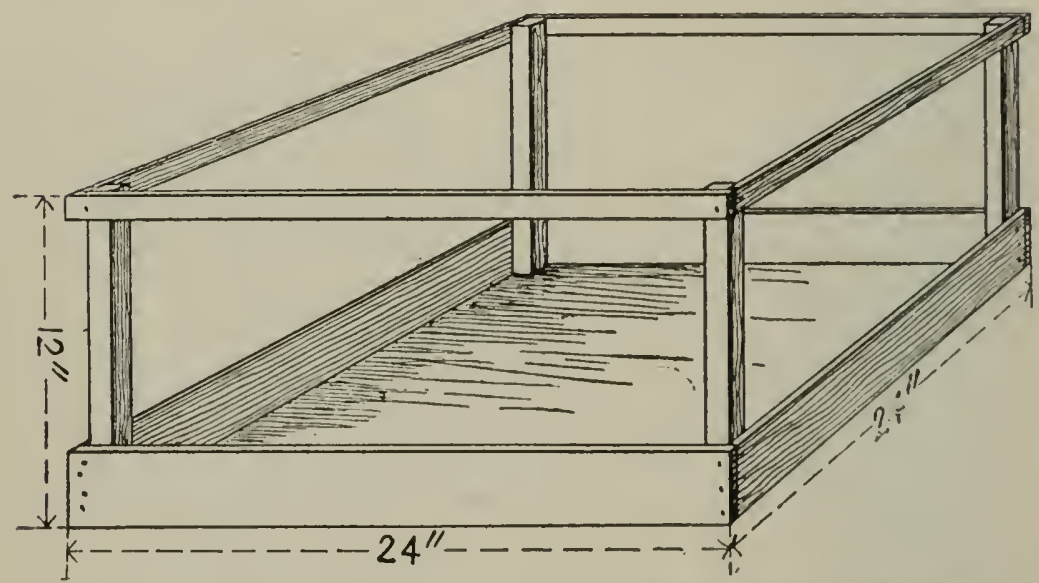

FIG. 55-DEVICE FOR DISPLAYING CELERY ON RETAIL MARKET

This device, which is illustrated in Fig. 55, consists of a shallow pan of galvanized iron together with a framework for holding the celery in an upright position. About an inch of water is kept in the bottom of the pan, which aids in keeping the celery in good condition until used. These holders can be of neat design, and if placed in a prominent part of the retail store they show the celery to the best advantage. 


\section{CHAP'TER XIV}

\section{Varieties of Celery}

Celery is listed in the seed trade catalogues under 75 or 100 varietal names, many of which, however, are synonymous. Fully 85 per cent. of the commercial crop grown in this country is of the self-blanching type, particularly Golden Selfblanching and White Plume. The varieties that do not have the self-blanching character are perhaps a little more hardy and disease-resistant. The selfblanching character is a sort of albinism acquired by breeding and selection and has resulted, to a limited degree at least, in the constitutional weakening of the plant. The self-blanching tendency is of so great advantage in a commercial variety that the growers are willing to sacrifice a part of the hardiness in order to secure a plant that will blanch readily.

Self-blanching Varieties._White Plume is a rapicl growing variety; height 20 to 24 inches; stems long. slender, broadened at base; foliage light green, spreading; inner stems and leaves pale green or white; blanches easily; rearly for market early.

Golden Self-blanching.-Rather slow growing at first; somewhat dwarf, 14 to 20 inches in height; stems short, thick, and golden yellow color, casily blanching to a rich creamy white; foliage abundant, 
compact; entire habit of growth stocky and close. This is the principal commercial variety.

Snow White.-A dwarf variety, similar in many respects to White Plume but much smaller; growth compact; readily blanches to a pure white color.

Rose Ribbed Golden Self-blanching.-Similar to Golden Self-blanching except that it has a tinge of rose color on the ribbing of the stems.

Late Keeping Varieties.-Fin de Siecle.-Plants very stocky; stems thick and maintain almost uniform size throughout their length; light green in color, blanching to a golden yellow; very crisp and tender. This is a desirable variety for winter keeping.

Perfection Hearticull.-Slightly dwarf; bunches expanded at base; height about 20 inches; stems thick, ribs prominent; green but blanches to a pure white. A good keeping variety.

Schumacher.-Slightly dwarf; about 20 inches high; bunches compact, stems thich green, blanching to a golden yellow. A splendid keeper and highly recommended for winter use.

Giant Pascal.-Immense size, frequently $3^{0}$ to $3^{6}$ inches in height; inclined to be somewhat coarse: foliage green, spreading; stems blanch to a pure white. A late variety, suitable only for winter use.

Evans' Triumph.-Medium dwarf; 16 to 18 inches high; bunches and stems of almost uniform size throughout; ribs prominent; foliage and stems a deep green, but blanch to almost a pure white; a good keeper.

Winter Queen.-A large growing variety of the 


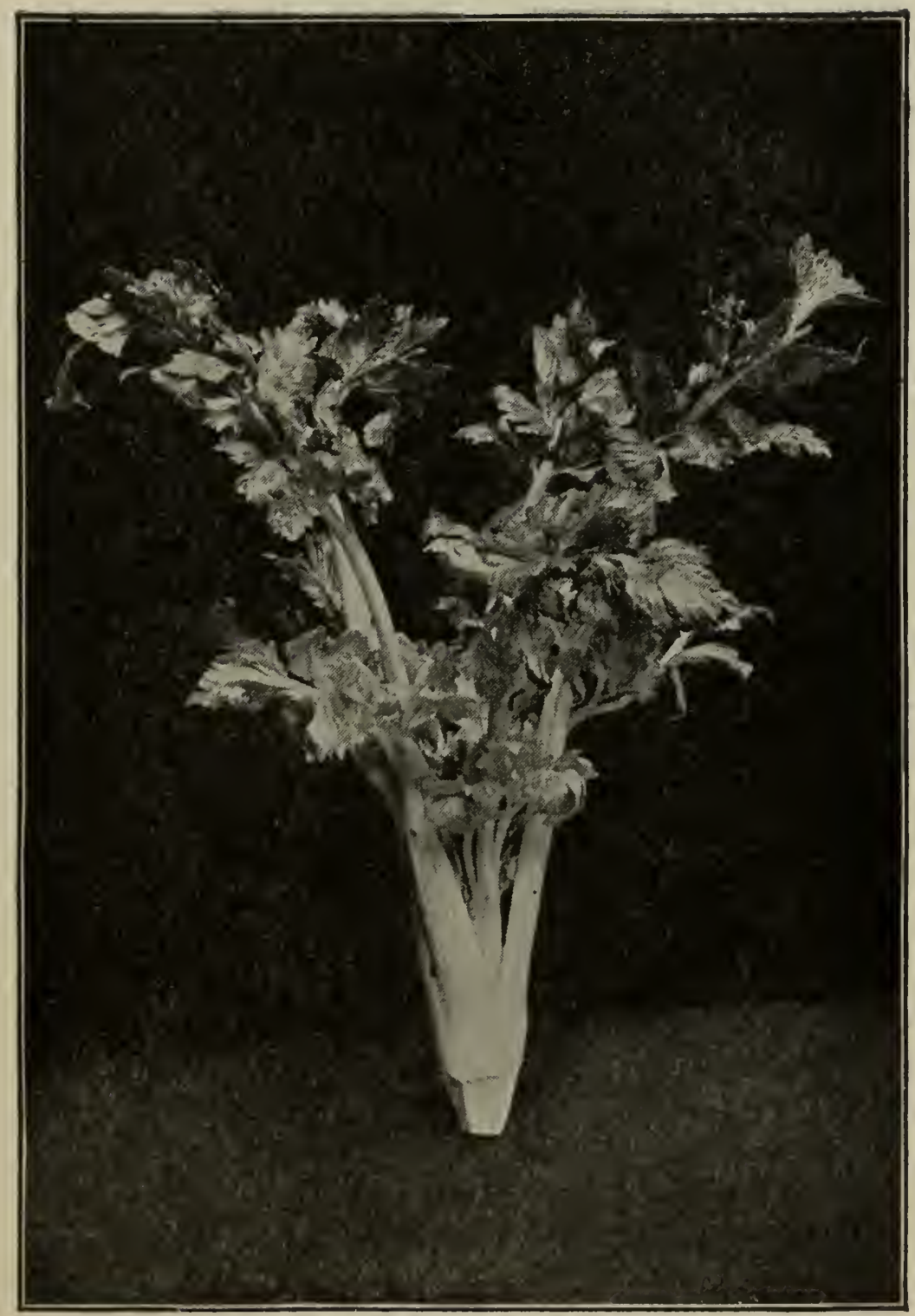

FIC, 56-TYPICAL PIANT OF GOI.DEN SELF-RLANCHING. READY FOR USE 
Giant Pascal type; height about 24 inches; expanded at base; ribs prominent; foliage deep green ; has numerous offshoots or suckers around base of plant. A good keeper.

Pink Plume.-Medium dwarf; has pink tinge on outer side of stems, but this is partially lost in blanching; has a rich flavor and good keeping qualities, but is not a strong grower.

Varieties for Home Use.-In the selection of the varieties to be grown one must be guided by the quantity clesired and whether the crop is to be used during the late summer and autumn or kept for winter by storing. The principal early varieties are White Plume and Golden Self-blanching. White Plume will produce edible stalks at an earlier date, but it is not so sturdy a grower or as well adapted to autumn and early winter use as the Golden Selfblanching. There are a number of good varieties for late winter use, among which may be mentioned, Fin de Siecle, Schumacher, Giant Pascal, Evans' Triumph, Winter Queen, and Pink Plume. These varieties do not blanch as readily as White Plume or Golden Self-blanching, but are better adapted to long keeping, and when properly blanched are superior in flavor. It is not practical to plant more than two varieties for home use, and one of these should be an early self-blanching and the other a long keeping sort. Five hundred plants will be sufficient for the use of the average family, and of these 200 should be early and 300 late. There are a number of varieties having a pink tinge of color to their stems, and these are attractive, have a fine 
flavor, when properly blanched, are good keepers, and are deserving of more general use in home gardens.

Celeriac or turnip-rooted celery differs from the true celery in that it produces an enlarged fleshy root and small leaves. Celeriac is cultivated the same as celery except that it may be planted in rows I foot apart and does not require banking or blanching in any way. The fleshy roots of celeriac are used for cooking and in soups the same as the roots and stems of the common celery.

Varieties for marketing do not differ greatly from those recommended for home use, except that for market the early or self-blanching sorts are used almost exclusively. For extra early celery White Plume is planted, but Golden Self-blanching is employed for fully 75 per cent. of the entire crop grown for market. Giant Pascal and Evans' Triumph are largely used for storage purposes, but the acreage devoted to this line of production is comparatively small. Those who contemplate growing celery for the autumn and early winter market should invariably select Firench grown seed of Golden Selfblanching at the start, and then experiment with other strains and varieties in a small way to deter. mine if the original selection can be improved upon. 


\section{CHAPTER XV}

\section{Profits Derived from Celery Culture}

WHERE celery is grown for use on the home table, the cost of production is very small and cannot be separated from the general maintenance of the garden; the profits, however, can be calculated only by summing up the enjoyment and health derived from its use. Where the family is small, and there is a market or grocery near by, it may be more eco. nomical to purchase the supply of celery for home use, but is must be borne in mind that when celery is secured in this manner it is rarely so fresh and crisp as if directly from the home garden.

In commercial celery culture the cost of production and the profits obtained will be governed by numerous local conditions, but as a rule the expenditures and results for an acre will be about as follows :

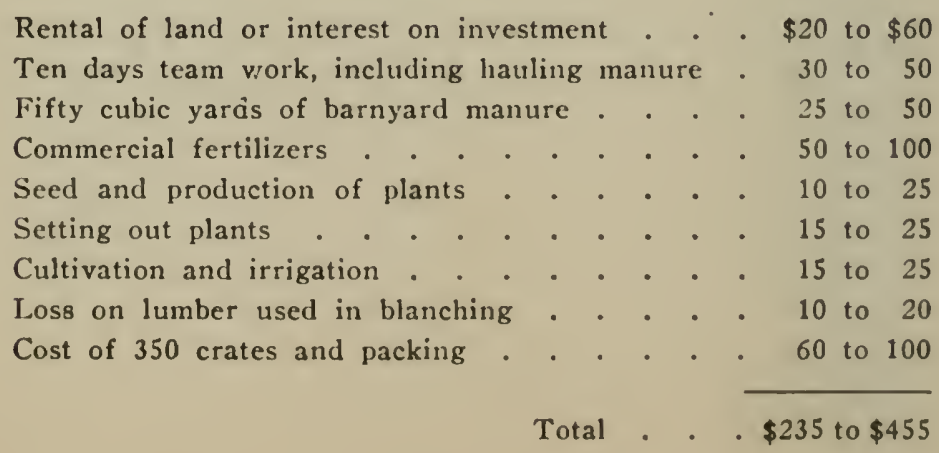


An acre of celery should reasonably yield from 250 to 350 crates, worth $\$ 2$ per crate at the shipping point, or $\$ 500$ to $\$ 700$ an acre. The lowest net balance then would be $\$ 45$ per acre, and the highest under the above estimate $\$ 565$ an acre. Commercial growers as a rule figure on a net return of about $\$ 100$ an acre, and cases are on record where an acre has produced $\$ 1,250$ worth of celery at a cost of $\$ 450$, or a net return of $\$ 800$; this was accomplished on new Florida land, highly fertilized, and the crop sold for about 40 cents a dozen at the shipping point. Some of the growers in Michigan claim that celery can be produced for I5 cents per dozen with fair profit, but the net returns are certainly not large at this figure. Celery may undoubtedly be grown profitably for 25 cents per dozen at the shipping point, provided the crop does not fail oftener than one year in five. It is not desirable that a grower should begin on a large scale, but he should begin with I or 2 acres and gradually increase his acreage until he has all his labor can handle profitably. 


\section{CHAPTER XVI}

\section{The Production of Celery Seed}

Localities Where Grown.-The greater portion of the world's supply of celery seed is grown in southern Europe and on the Pacific coast of the United States. A portion of the seed sold as French grown is produced in Algeria, but the greater part of it comes from Italy, where the cost of production is low. In America celery seed has been produced in several localities aside from the Pacific coast, especially in New Jersey, Delaware, Pennsylvania, and New York.

Method of Growing.-The principle of celery seed production is to sow seed during the latter part of the season in long narrow beds the surface of which is a trifle below the general level of the surrounding soil. As a rule these beds are I4 to 20 inches in width, and ample spaces left between them. The seedlings are allowed to grow in the beds during the autumn, and as winter approaches a light covering is provided to prevent the roots becoming frozen. As soon as the season opens in the spring, the plants are lifted and reset 6 or 7 inches apart in long parallel rows where they will produce seed during the early summer.

Local Production of Seed.-Any celery grower can produce seed on a small scale by making a late 
sowing in a spent hotbed or in a cold-frame, allowing the plants to remain in the bed, with sufficient protection to prevent the roots becoming frozen, until the following spring. During the early spring the plants should be lifted and the most perfect ones planted in rows where they may be cultivated during the first part of the season, or until they shoot to seed. The flower stems are from 2 to 3 feet in height and the flowers and seeds are borne in umbels or clusters. As the seeds become ripened they should be gathered and spread on cloth screens in a shaded place until dry. The seeds should then be stored in a dry place until wanted for planting during the following winter or spring. 


\section{CHAPTER XVII}

\section{Celery Growing for Health, Pleasure and Profit}

In the preceeding chapters we have considered the production of celery for home use and for marketing, but have given very little attention to the desirability of celery growing as a pleasant vocation. In the cultivation of a garden, or a small area of some such crop as celery, the business or professional man can find a source of refreshment and a means of relaxation from the every-day cares of life. There is something so clean and refreshing about the straight, regular rows of celery plants, and the color of the celery foliage is perhaps the most restful that the eye can look upon. An hour's time, either morning or evening, spent in the cultivation of a plot of celery will bring reward in more ways than the mere production of so many dozens of plants for home use or market. There is something about the smell of the fresh earth together with the odor of growing celery that will whet one's appetite to the point of starvation.

We hear a great deal about the nerve-building properties of celery, and the uses of celery as a tonic, but as digestion holds sway over both body and mind, we can readily conclude that the benefits arising from the cultivation and use of celery are large- 
ly through improved digestion. The main difference between the use of celery and other similar salad crops is found in the fact that owing to the superior

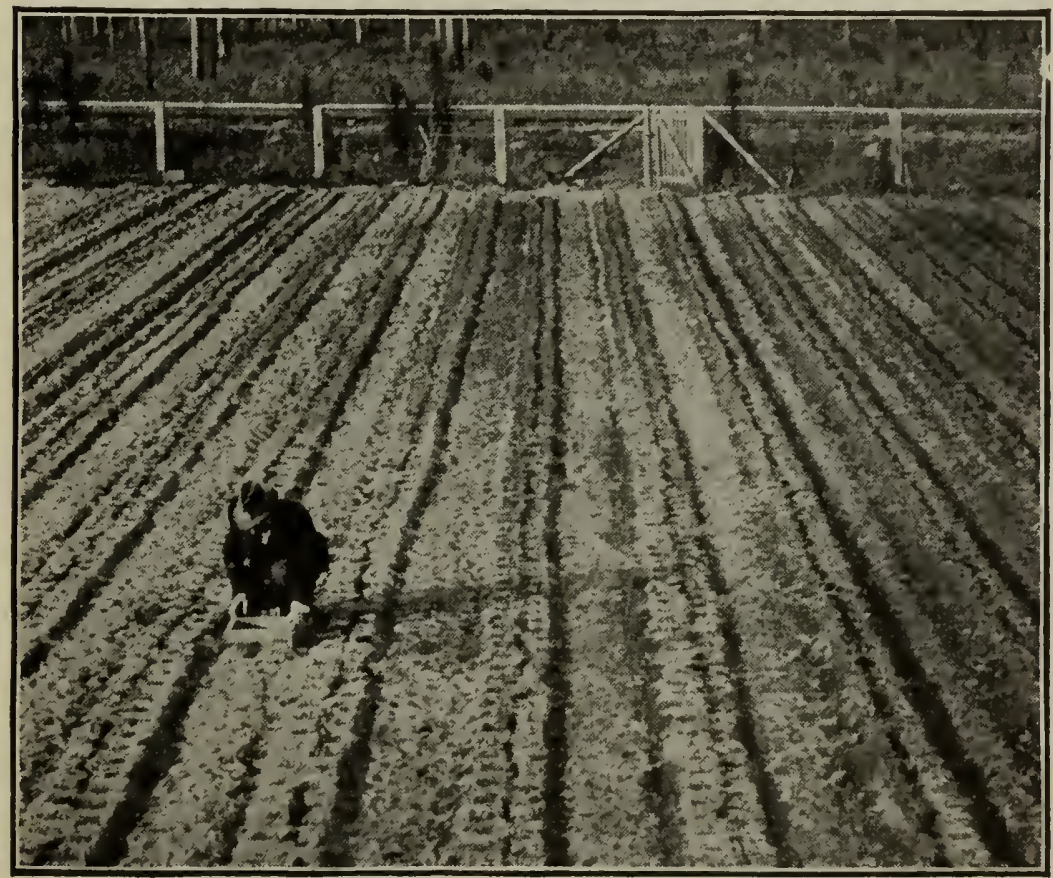

FIG. 57-FLORIDA CELERY LAND

Rows slightly ridged, and evenly marked. Crop in double rows planted. The boxes over the inlets to system of subirrigation from

an artesian well near by

(Photo by Prof. W. G. Johnson)

flavor of celery we are inclined to eat it oftener and more bountifully.

Celery culture on a moderate scale is one of the most desirable lines of work for persons whose health demands that they live in outdoor life. During the early springtime the care of the plant beds will require but a short time each day; however, it 


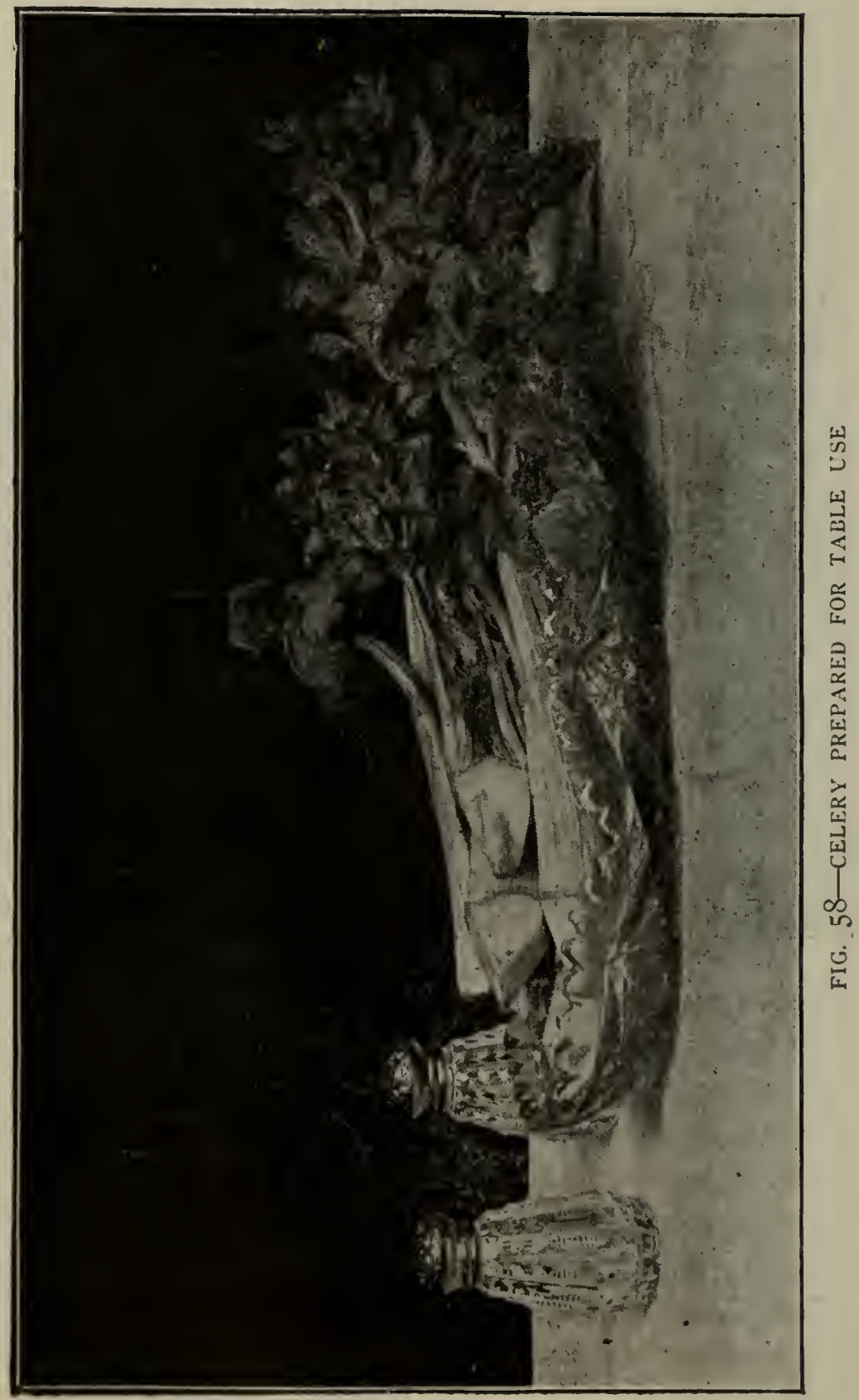


will be necessary that this care should be at intervals throughout the day. Later, the setting of the plants during the pleasant days of May and Jume will bring the person conducting the work in close contact with the soil. During the summer months, the work of caring for the celery can all be performed during the morning and evening, without attention during the heated part of the day. In the autumn, when the crop is ready for marketing or storing, the labor can be performed during the middle of the day, or at least after the air has become dry and pleasant.

We are often requested to furnish information regarding lines of work in which women can engage in order to earn a little money for themselves. Aside from the rough work of fitting the land, there is perhaps no cleaner or more pleasant occupation than celery growing for women to engage in; besides it provides for them a greater proportion of outdoor life.

The capital required for starting a small celery growing enterprise is not great. Celery culture offers special inducements for boys and young men who desire to get a start in a paying business. With $\mathrm{I} / 2$ to I acre of good celery land at his disposal, an industrious young fellow can easily clear from $\$$ IOo to $\$ 300$ during a season, and the greater part of the work can be done during vacation and outside of school hours. The main points to be considered when contemplating a small venture in celery growing are: (I) climatic conditions; (2) adaptability of available land; (3) marketing facilitics; 


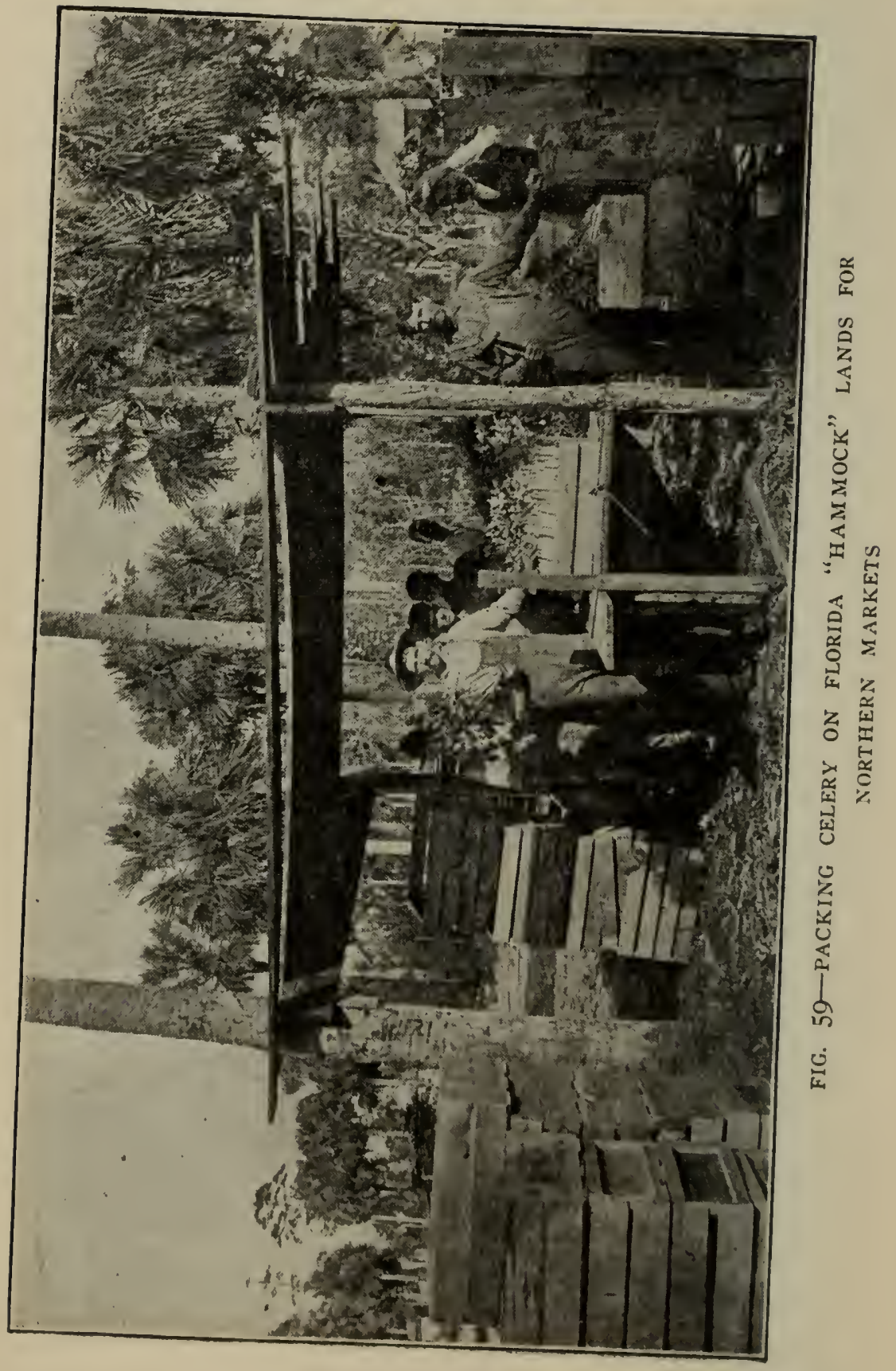


(4) securing of fertilizers; and (5) irrigation facilities. The requirements along these lines have been discussed under separate heads in this book, the only difference being that on a small scale the character of the land, securing of fertilizers, and irrigation facilities can be more easily controlled, and it may even be possible to build up a market where no demand now exists.

Many persons have the impression that celery growing is an intricate process requiring special conditions, skill, and equipment, but such is not the case. Celery is no more difficult to grow than the majority of garden crops, but it has a few peculiarities the understanding of which only adds interest to the work. 


\section{INDEX}

Acid phosphate, 18, 29, 30, 33.

Acme harrow, 3.

Ammonia water, 83,84 .

Ammonium salts as fertilizers, $29,30,32$.

Areas adapted to celery culture, 10

Arsenical poisoning, 92.

Availability of fertilizers, 16, 32, 33,

Bacterial disease, $81,82$.

Barnyard manure, value and metliods of handling, $20,21$.

Blanching celery for use, 95, 103; for storing and wintc: use, 103; time required for blanching, 98; various methods of blanching, 103; with boards, 96; with eartl, 99; with tiles, 102.

Blight of celery, 78, 79 .

Blood and bone, 30, 32 .

Boards for blanching, 96, 97, 98, 99 .

Bone black, 32.

Bone meal, 17, 32.

Bordeaux dust, 78 .

Bordeaux mixture, methods of preparing, 84,85 .

Botanical classification of celery, 1.

Boxes for handling celery from field to storeliouse, 110.

Breaking plow, 8.

Bunching and packing, 120.

Isunching device, 122.

Buncli of celery containing one dozen, 121.

Calcium carbonate, 19.

Calcium oxide, 19.

Calcium phosphate, 18.

Calcium, sources of, 19

Capital required for celery-growing on small scale, 137.

Carbonate of copper, 83.

Carrot rusi fly, 93.

Caterpillars, 92.

Celeriac, 129.

Celery liiller, 98, 100.

Celery looper, 93.

Celery seed, 35.
Celery seed production, 132, 133.

Cellars, use for storing, 107, ventilation of, 107.

7, Cercospora apii, 78, 79.

Chemical content of fertilizers, 17.

Climatic requirements of celery, 2 .

Cold-frames, 41.

Cold-storage, 111.

Copper carbonate, 83, 84.

Copper sulpliate, 84 .

Corn on celery land, 8.

Cost of production per acre, 130.

Cost per acre for setting plants, 56.

Cotton-seed meal, 33.

Cover crops, 12.

Cowpeas, 8.

Crates, shipping, 114, 116, 117, 123.

Cultivation, frequency of, 61 ; depth of, 61 ; tools adapted to, 61 .

"Damping," 41, 77, 78.

Dates of planting, $50,51,52$.

Deluge sprinkler, $69,70,71$.

Deptl of planting, $37,44,55$.

Dibbles used for setting plants, 56 .

Digger in operation, 110.

Diseases of celery, 77; blanch-rot or lieart-rot, 81 ; blight, 78,79 ; "dlamping," 77; leaf-spot, 80; rootknot, 82 ; rust, 81 .

Disk harrow, 9 .

Distances to plant, 56,58 .

Drag for leveling land, 12

Drainage, 7; open ditches, 7; tile drains, 7 .

Drain tiles used for blanching, 102.

Dried blood, 17, 32 .

Early history of celery, 1, 2.

Early spring crops on celery land, 11.

Evans' Triumpli variety, 126.

Extent of celery industry, 2 .

Fertilizers, 16-34; application of, 23. 27 ; cost per acre, 25; determina. tion of value from printed formula, 24; home mixing of, 28.34; natural fertility of soils, 16 ; quan- 


\section{Fertilizers-continued}

tity to apply, 25,26 ; requirements of celery, 24; table of fertilizer values, 32,33 ; time for apply. ing, 26, 27, 28 .

Fillers for use in mixing fertilizers, 31.

Fin de siecle variety, 126.

Fish refuse or scrap, 22.

Flumes, wood for conducting wa. ter, 68.

Float or drag for leveling soil, 12.

"Floats," 18.

Food value of celery, 2.

liungicides, $83,84,85,89$.

Fusarium, 78.

Giant Pascal variety, 126.

Golden Self-blanching variety, 125, 127.

Grasshoppers, 91.

Guano, Peruvian, 23.

Habitat of celery, 3, 7, 65 .

Handling celery, methods of, 109.

Harrow, acme, 10; disk, 9; Meek. er, 13; spring-tooth, 9 .

Hauling, wagon adapted to, 110.

Health fulness of celery growing, 134.

Heart-rot or blanch-rot of celery, 81 .

Heating for storehouse, 104.

Heterodera radicicola, 82 .

Holders for use on retail markets, 124.

House for storing celery, 108.

Horse-boots, 14.

Hotbeds, care of, 41; covering for, 40 ; permanent, 39 , temporary, 38 .

Insecticides, 91, 92, 93.

Insects injurious to celery, 90-93; carrot rust fly, 93; celery cater. pillar, 92; celery leaf-tyer, 91; celery looper, 93; grassloppers, 91; tarnished plant bug, 92; zebra caterpillar, 92 .

Insoluble fertilizers, 16, 32 .

Irrigation, 65-76; cost of applying water, 66; deluge sprinkler method of applying, $66,70,71$; metlods of applying water, 67; 011 muck soils, 67; quantity of water required by celery, 66; skimmer sprinkler method, 71, 72, 73; sources of water for irrigation. 65; subirrigation method of ap.
Irrigation-continued

plying water, $72,74,75,76$; temperature of water for irrigation, 76.

Kainit, 18, 33.

Kerosene emulsion, 92.

Labor necessary for celery cul. ture, 6.

Leaf-spot diseasc, 80.

Leaf-tyer, the celery, 91.

Level culture, 61.

Lime, effect on soils, 19.

Limestone, 18.

Looper, the celery, 93.

Lygus pratensis, 92.

Machine for lifting celery, 110.

Machine for marketing rows, 13, 15.

Mamestra picta, 92.

Manures for use on celery land, 20. 21,22 ; from fowls, 22 ; value of barn manures, 21.

Marker, horse, drawn, 14; wheelbarrow, 15.

Markets for celery, home and ship. ping, 5.

Marl, use on celery land, 19.

Maturity, time of, 50,51 .

Meat meal, 17.

Meeker harrow, 13.

Mice and rats, 93.

Moisture, conservation of, 60 ; in seed-bed, 45, 46; retention by culture, 61,64 .

Muck soils, 4.

Mulch around plants, 59; soil or dust, 64,65 .

Muriate of potash, 18, 29, 30.

Natural fertility of soils, 16.

"Ncw Celery Culture," 59.

New land, treatment of, 8.

Night soil as a fertilizer, 23.

Nitrate of soda, $25,27,28,31,32$.

Nitrogen, sources of, 17; effect of, 28.

Number of celery seeds in an ounce, 1.

Oyster shells, 19.

Packing-lrouse, plan of, 119.

Packing, methods of, 114; in field, 115; in house, 117.

P'ans used for handling plants, 53.

Paper twine, 101.

Papilia asterias, 92. 
Paris green, amount to use, 91, 93; for grasshoppers, 91; for celery looper, 93.

Peas, garden, 11.

Peat bogs, 4.

Perfection heartwell variety, 126.

Peruvian guano, 23.

Phlyctaenia ferrugalis, 91.

Phosphoric acid, 22, 28, 29, 30, $32,33$.

Phorphorous, sources of, 18.

Phyllosticta apii, 81.

Pink plume variety, 128.

Pithiness of celery, $87,88,89$.

Plant foods, 16.

Planting in the open ground, 43-53; dates of, 50,52 ; depth of, 55 ; distances apart, 56,58 ; in solid beds, 58 , 59; table of planting distances 58 .

Plants, lifting from seed-bed, 52; packing for shipment, 53 .

Pleasure in celcry growing, 134.

Plow, heavy breaking, 8 ; subsoiling, 9.

Plowing, depth of, 8, 9; time for, $10,11$.

Plusia simplex, 93.

Potassium, sources of, 18.

Poultry injurious to celery, 94.

Preparation of seed-beds, 36, 42, 43, 44.

Preparing for planting, 13.

Preparing land for cclery, 8.

Prices, average, 131 .

Production of plants, 35-51.

Production of seed, 132.

Profits derived from celery cul. ture, 131.

Protecting plants in seed-bed, 45 .

Psila rosea, 93.

Puccinia bullata, 82.

Puddling, 59.

Pumping water for irrigation, 66.

Returns from one acre, 131.

Root-knot of celery, 82 .

Roots, character of, 47; depth of, 61; effect of transplanting upon, 47.

Rose-ribbed Golden Sclf-blanching variety, 126.

Rotation on celery land, 27.

Rust of celery, 82 .
Salt as a fertilizer, 19, 20.

Sandy loams, 4.

Sanitary precautions in handling celery, 122.

Sash, for covering hotbeds, 40 .

Sawgrass marshes of Florida, 4.

Schumacher variety, 126.

Sectional roller, 9, 10.

Seed-bed, indoor, 36; outdoor, 45.

Seed, European grown, 35; method of growing, 132; vitality of, 35 .

Septoria petroselini var. apii, 80 .

Sewage as a fertilizer, 23.

Shading for plant beds, 46.

Shipping in the rough, 112.

Skinner system of irrigating, 71, $72,73$.

Snow white variety, 126.

Soils adapted to celery growing, 4 .

Solubility of fertilizers, $32,33$.

Sowing in drills, $37,44$.

Spraying machines, 86.

Spraying mixtures, $83,84,85$.

Spraying, time for and frequency of, 83-86.

Spring crops on celery land, 12.

Spring-tooth harrow, 9.

Sprinkler system of irrigating, 69, 73.

Stable manure, 20.

Sterilization of soils, 42.

Storage, 104-108; in celery house, 108 ; in cellars, 107 ; in pits, 106; temperature of storage houses. 111 ; ventilation of, 104 .

Subsoiling, 9.

Sulplate of ammonia, 17, 29, 30, 32 .

Sun-scald, 21.

Tankage, 17, 32.

Tarnished plant bug, 92 .

Tcmperature of storage houses, 111.

Temperature of water for irrigation, 76.

Tile drainage, 7 .

Tillage, 61-64.

Time for planting, 50 .

Time for plowing, 10, 11.

Time for sowing seed, 50.

Time required to produce a crop, 50

Tobacco stems, 33.

Tools for cultivation, $62,63$.

Transplanting, 47.

Transplanting machines, 56. 
Transportation, 5, 115.

Trays for sowing seed and transplanting, 36.

Trenching, 107.

Trimming for market, 116, 118.

Value per acre, 131.

Vareties of celery, 125-129; for Window box, 36 .

home use, 128; for market, 129; Winter Queen variety, 126.

for late keeping, 126; Self-blanch. Wood ashes, 18, 25. ing, 125.

Washing machine, 119.

Weeds, 61.

Weeders, 63.

White Plume variety, 125.

Wheel hoe, 62,63 .

Wild celery of Europe, 1.

Ventilation of storage houses, 111. Zebra caterpillar, 93.

Washing celery, 116-119. 


\section{STANDARD BOOKS}

PUBLISHED BY

\section{ORANGE JUDD COMPANY}

NEW YORK

Ashland Building
CHICAGO

People's Gas Building 150 Michigan Avenue

Any of these books will be sent by mail, postpaid, to any part of the world, on receipt of catalog price. We are always happy to correspond with our patrons, and cordially invite them to address us on any matter pertaining to rural books. Send for our large illustrated catalog, free on application.

\section{First Principles of Soil Fertility}

By Alfred Vivian. There is no subject of more vital importance to the farmer than that of the best method of maintaining the fertility of the soll. The very evident decrease in the fertility of those soils which have been under cultivation for a number of years, combined with the increased competition and the advanced price of labor, have convinced the intelligent farmer that the agriculture of the future must be based upon more rational practices than those which have been followed in the past. We have felt for some time that there was a place for a brief, and at the same time comprehensive, treatise on this important subject of Soil Fertility. Professor Vivian's experience as a teacher in the short winter courses has admirably fitted him to present this matter in a popular style. In this little book he has given the gist of the subject in plain language, practically devoid of technical and scientific terms. It is pre-eminently a "First Book," and will be found especially valuable to those who desire an introduction to the subject, and who intend to do subsequent reading. Illustrated. $5 \times 7$ inches. 265 pages. Cloth.

Net, \$r.oo

\section{The Study of Corn}

By Prof. V. M. Shoesmith. A must helpful book to all farmers and students interested in the selection and improvement of corn. It is profusely illustrated from photographs, all of which carry their own story an' contribute their part in making pictures and text matter a clear, concise and interesting study of corn. Illustrated. $5 \times 7$ inches. roo pages. Cloth. . . . . . . . Net, \$0.50 


\section{Farm Grasses of the United States of America}

By William Jasper Spillman. A practical treatise on the grass crop, seeding and management of meadows and pastures, cescription of the best varieties, the seed and its impurities, grasses for special conditions, lawns and lawn grasses, etc., etc. In preparing this volume the author's object has been to present, in connected form, the main facts concerning the grasses grown on American farms. Every phase of the subject is viewed from the farmer's standpoint. Illustrated. 248 pages. $5 \times 7$ inches. Cloth. . . . . \$1.00

\section{The Book of Corn}

By Herbert Myrick, assisted by A. D. Shambia, E. A. Burnett, Alber' W. Fulton, B. W. Snow, and other most capable specialists. A complete treatise on the culture, marketing and uses of maize in America and elsewhere for farmers, dealers and others. Illustrated. 372 pages. $5 \times 7$ inches. Cloth.

\section{The Hop-Its Culture and Care, Marketing and Manufacture}

By Herbert Myrick. A practical handbook on the most approved methods in growing, harvesting, curing and selling hops, and on the use and manufacture of hops. The result of years of research and observation, it is a volume destined to be an authority on this crop for many years to come. It takes up every detail from preparing the soil and laying out the yard, to curing and selling the crop. Every line represents the ripest judgment and experience of experts. Size, $5 \times 8$; pages, 300; illustrations, nearly 150; bound in cloth and gold; price, postpaid. . . . . . . . . . . \$1.50

\section{Tobacco Leaf}

By J. B. Killebrew and Herbert Myrick. Its Culture and Cure, Marketing and Manufacture. A practical handbook on the most approved methods in growing, harvesting, curing, packing and selling tobacco, with an account of the operations in every department of tobacco manufacture. The contents of this book are based on actual experiments in field, curing barn, packing house, factory and laboratory. It is the only work of the kind in existence, and is destined to be the standard practical and scientific authority on the whole subject of tobacco for many years. 506 pages and 150 original engravings. $5 \times 7$ inches Cloth. . . . . . \$2 m 


\section{Alfalfa}

By F. D. Coburn. Its growth, uses, and feeding value. The fact that alfalfa thrives in almost any soil; that without reseeding, it goes on yielding two, three, four, and sometimes five cuttings annually for five ten, or perhaps Ioo years; and that either green or cured it is one of the most nutritious forage plants known, makes reliable information upon its production and uses of unusual interest. Such information is given in this volume for every part of America, by the highest authority. Illustrated. 164 pages. $5 \times 7$ inches. Cloth. \$0.50

\section{Ginseng, Its Cultivation, Harvesting, Marketing and Market Value}

By Maurice G. Kains, with a short account of its history and botany. It discusses in a practical way how to begin with either seeds or roots, soil, climate and location, preparation planting and maintenance of the beds, artificial propagation, manures, enemies, selection for market and for improvement, preparation for sale, and the profits that may be expected. This booklet is concisely written, well and profusely illustrated, and should be in the hands of all who expect to grow this drug to supply the export trade, and to add a new and profitable industry to their farms and gardens, without interfering with the regular work. New edition. Revised and enlarged. Illustrated. $5 \times 7$ inches. Cloth. . . . .\$0.50

\section{Landscape Gardening}

By F. A. WAUGH, professor of horticulture, university of Vermont. A treatise on the general principles governing outdoor art; with sundry suggestions for their application in the commoner problems of gardening. Every paragraph is short, terse and to the point, giving perfect clearness to the discussions at all points. In spite of the natural difficulty of presenting abstract principles the whole matter is made entirely plain even to the inexperienced reader. Illustrated. I 52 pages. $5 \times 7$ inches. Cloth. . . . . Net, \$o.75.

\section{Hedges, Windbreaks, Shelters and Live Fences}

By E. P. Powell. A treatise on the planting, growth and management of hedge plants for country and suburban homes. It gives accurate directions concerning hedges; how to plant and how to treat them; and especiany concerning windbreaks and shelters. It includes the whole art of making a delightful home, giving directions for nooks and balconies, for bird culture and for human comfort. Illustrated. I40 pages. $5 \times 7$ inches. Cloth. . . . . . . . . \$0.50 


\section{The New Egg Farm}

By H. H. Stoddard. A practical, reliable manual on producing eggs and poultry for market as a profitable business enterprise, either by itself or connected with other branches of agriculture. It tells all about how to feed and manage, how to breed and select, incubators and brooders, its laborsaving devices, etc., etc. Illustrated. 331 pages. $5 \times 7$ inches. Cloth.

\section{Poultry Feeding and Fattening}

Compiled by G. B. Fiske. A handbook for poultry keepers on the standard and improved methods of feeding and marketing all kinds of poultry. The subject of feeding and fattening poultry is prepared largely from the side of the best practice and experience here and abroad, although the underlying science of feeding is explained as fully as needful. The subject covers all branches, including chickens, broilers, capons, turkeys and waterfowl; how to feed under various conditions and for different purposes. The whole subject of capons and caponizing is treated in detail. A great mass of practical information and experience not readily obtainable elsewhere is given with full and explicit directions for fattening and preparing for market. This book will meet the needs of amateurs as well as commercial poultry raisers. Profusely llustrated. I60 pages. $5 \times 7 \frac{1}{2}$ inches. Cloth. . . \$0.50

\section{Poultry Architecture}

Compiled by G. B. FISKE. A treatise on poultry buildings of all grades, styles and classes, and their proper location, coops, additions and special construction; all practical in design, and reasonable in cost. Over Ioo illustrations. I25 pages. $5 \times 7$ inches. Cloth. . . . . . . . . . \$0.50

\section{Poultry Appliances and Handicraft}

Compiled by G. B. Fiske. Illustrated description of a great variety and styles of the best homemade nests, roosts, windows, ventilators, incubators and brooders, feeding and watering appliances, etc., etc. Over 100 illustrations. Over I 25 pages. $5 \times 7$ inches. Cloth. . . . . . . \$o.50

\section{Turkeys and How to Grow Them}

Edited by HERrERT MYrick. A treatise on the natural history and origin of the name of turkeys; the various breeds, the best methods to insure success in the business of turkey growing. With essays from practical turkey growers in different parts of the United States and Canada. Copiously illustrated. I 54 pages. $5 \times 7$ inches. Cloth. . . . \$1.00 


\section{Animal Breeding}

By Thomas Shaw. This nuok is the most complete and comprehensive work ever published on the subject of which it treats. It is the first book which has systematized the subject of animal breeding. The leading laws which govern this most intricate question the author has boldly defined and authoritatively arranged. The chapters which he has written on the more involved features of the subject, as sex and the relative influence of parents, should go far toward setting at rest the wildly speculative views cherished with reference to these questions. The striking originality in the treatment of the subject is no less conspicuous than the superb order and regular sequence of thought from the beginning to the end of the book. The book is intended to meet the needs of all persons interested in the breeding and rearing of live stock. Illustrated. 405 pages. $5 \times 7$ inches. Cloth. . . \$I.50

\section{Forage Crops Other 'Than Grasses}

By Thomas Shaw. How to cultivate, harvest and use them. Indian corn, sorghum, clover, leguminous plants, crops of the brassica genus, the cereals, millet, field roots, erc. Intensely practical and reliabie. Illustrated. 287 pages. $5 \times 7$ inches. Cloth. . . . . . . . . . . . \$1.00

\section{Soiling Crops and the Silo}

By Thomas Shaw. The growing and feeding of all kinds of soiling crops, conditions to which they are adapted, their plan in the rotation, etc. Not a line is repeated from the Forage Crops book. Best methods of building the silo, filling it and feeding ensilage. Illustrated. 364 pages. $5 \times 7$ inches. Cloth.

\section{The Study of Breeds}

By Thomas Shaw. Origin, history, distribution, characteristics, adaptability, uses, and standards of excellence of all pedigreed breeds of cattle, sheep and swine in America. The accepted text book in colleges, and the authority for farmers and breeders. Illustrated. 371 pages. $5 \times 7$ inches. Cloth.

\section{Clovers and How to Grow Them}

By Thomas Shaw. This is the first book published which treats on the growth, cultivation and treatment of clovers as applicable to all parts of the United States and Canada, and which takes up the entire subject in a systematic way and consecutive sequence. The importance of clover in the economy of the farm is so great that an exhaustive work on this subject will no doubt be welcomed by students in agriculture. as well as by all who are interested in the tilling of the soil. Illustrated. $5 \times 7$ inches. 337 pages. Cloth. Net : \$1.00 


\section{Farmer's Cyclopedia of Agriculture}

A Compendium of Agricultural Science and Practice on Farm, Orchard and Garden Crops, and the Feeding and Diseases of Farm Animals. . . . .

\section{By EARLEY VERNON WILCOX, Ph. D. and CLARENCE BEAMAN SMITH, M. S.}

Associate Editors in the Office of Experiment Stations, United States Department of Agricuiture

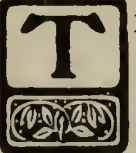

His is a new, practical, and complete presentation of the whole subject of agriculture in its broadest sense. It is designed for the use of agriculturists who desire up-to-date, reliable information on all matters pertaining to crops and stock, but more particularly for the actual farmer. The volume contains

\section{Detailed directions for the culture of every}

important field, orchard, and garden crop

grown in America, together with descriptions of their chief insect pests and fungous diseases, and remedies for their control. It contains an account of modern methods in feeding and handling all farm stock, including poultry. The diseases which affect different farm animals and poultry are described, and the most recent remedies suggested for controlling them.

Every bit of this vast mass of new and useful information is authoritative, practical and easily found, and no effort has been spared to include all desirable details. There are between 6,000 and 7,000 topics covered in these references, and it contains 700 royal $8 \mathrm{vo}$ pages and nearly 500 superb half-tone and other original illustrations, making the most perfect Cyclopedia of Agriculture ever attempted.

Handsomely bound in cloth. $\$ 3.50$ : half morocco (very sumptuous). \$4.50. postpaid 

STORAGE

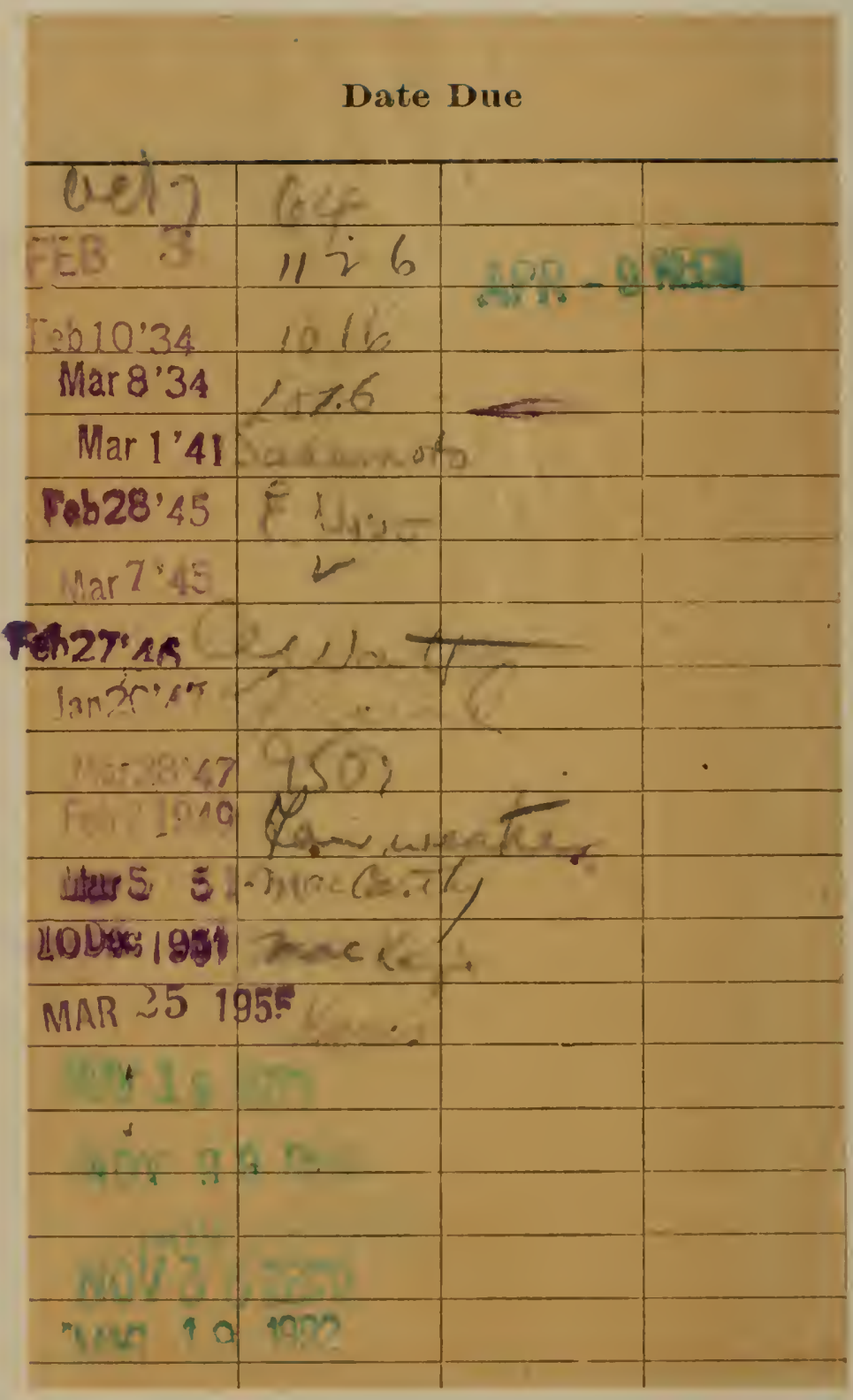




\section{5}
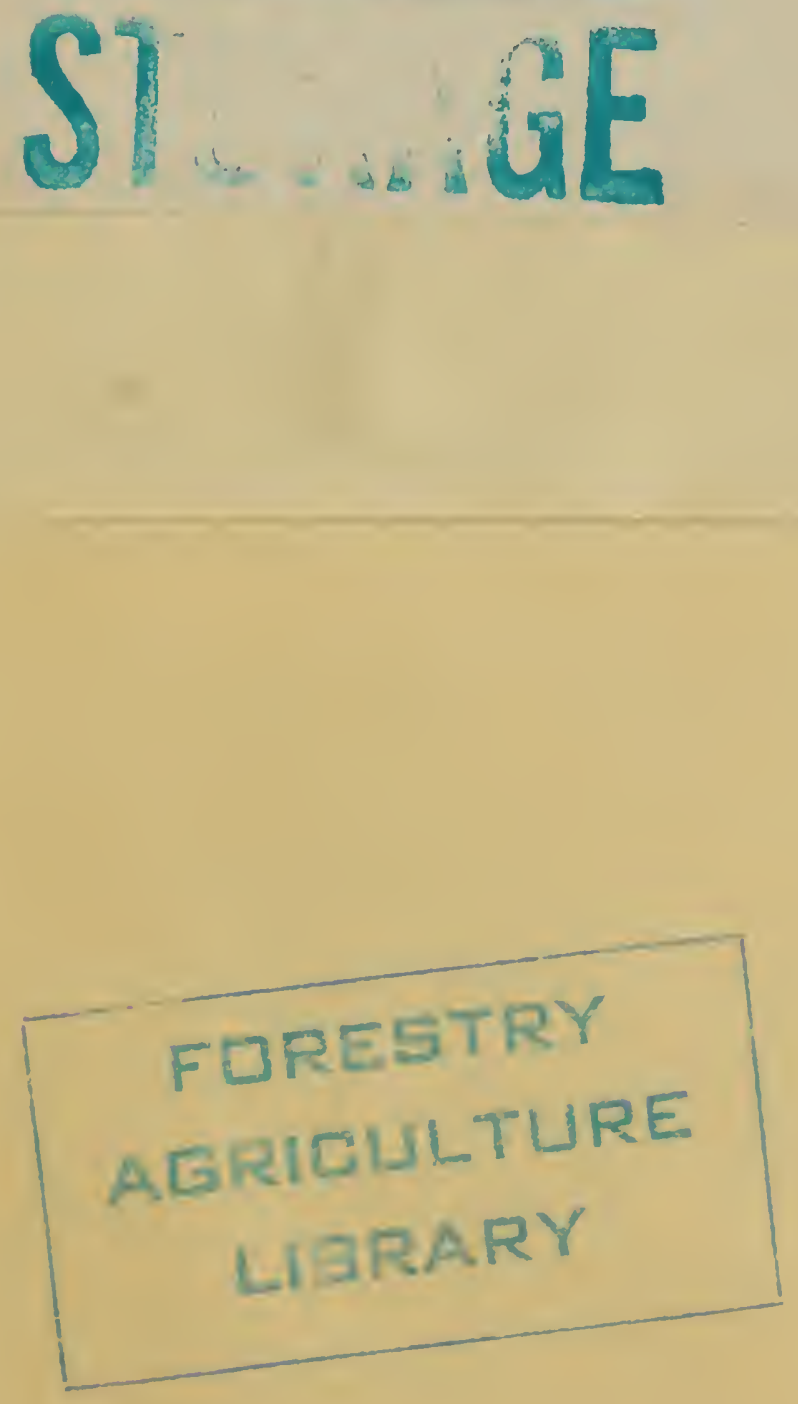
jul

1050

and

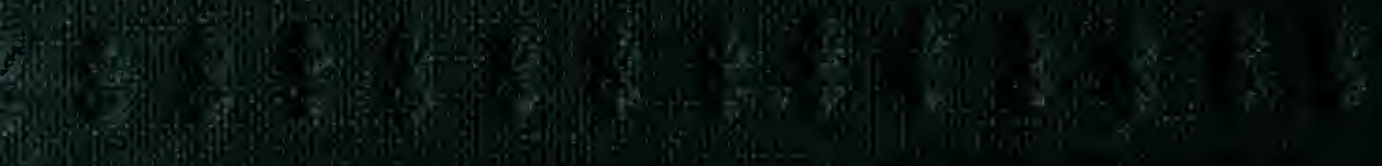

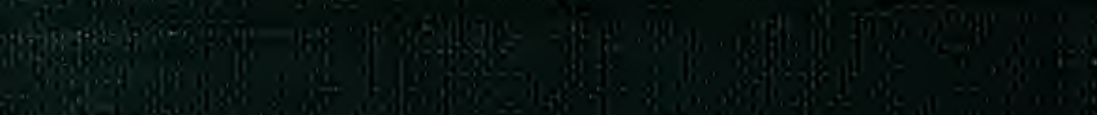

a.

(1)

$2=0$

(1)

19.8.

$\frac{1}{4} k^{6}$

7. 4 (4)

(2)

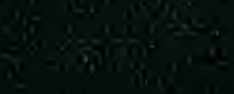

$\frac{1}{7}$ 